G $E \cup S$

Report file no.

22221

GRøNLANDS GEOLOGISKE UNDERSØGELSE

BuLLETIN No. 69

\title{
BASIC AND INTERMEDIATE IGNEOUS ACTIVITY AND ITS RELATIONSHIPS TO THE EVOLUTION OF THE JULIANEHÅB GRANITE, SOUTH GREENLAND
}

BY

JAN H. ALLAART

WITH 47 FIGURES AND 5 TABLES IN THE TEXT AND 3 PLATES

Reprinted from

Meddelelser om Gronland Bd. 175, Nr.1

KøBEN HAVN

BIANCO LUNOS BOGTRYKKERI A/S

1967 
GRØNLANDS GEOLOGISKE UNDERSØGELSE Bulletin No. 69

\section{BASIC AND INTERMEDIATE IGNEOUS ACTIVITY AND ITS RELATIONSHIPS TO THE EVOLUTION OF THE JULIANEHÅB GRANITE, SOUTH GREENLAND}

BY

JAN H. ALLAART

WITH 47 FIGURES AND 5 TABLES IN THE TEXT AND 3 PLATES

Reprinted from

Meddelelser om Gronland Bd.175, Nr.1

KØBENHAVN

BIANCO LUNOS BOGTRYKKERI A/S 


\begin{abstract}
In the area investigated, situated in the eastern part of the Julianehåb granite region, six granite varieties constitute large areas between which mainly ENEtrending belts of gneiss and metamorphic supracrustals are preserved. Much of the granite probably represents anatectic pre-Ketilidian basement. Three varieties belong to the 1st episode of Ketilidian plutonism. Three younger mainly allochthonous varieties (2nd episode) were generated in connection with basic and intermediate igneous activity.

One of the oldest (pre-1st episode) basic intrusive bodies was probably intruded into a granitic part of the pre-Ketilidian basement. Others occur in Ketilidian metavolcanics.

Six types of calc-alkali basic and intermediate intrusives postdate the 1st episode. The metadolerites are mainly concentrated in the Julianehåb granite region and are interpreted as intraorogenic. Some of the hypersthene gabbros might be contemporaneous with the metadolerites.

The first phase of the 2nd episode of Ketilidian plutonism is characterised by deformation, and emplacement of allochthonous granite bodies which was controlled by older fold structures. A slow process of consolidation in the cores of the bodies eventually permitted the intrusion of the synkinematic dykes mainly concentrated there. Before these dykes were intruded the crustal conditions in the margins of the bodies and outside permitted the intrusion of the pyroxene-bearing diorites and possibly of some hypersthene gabbros during the earlier stages of the formation of the Big-feldspar granite of the second phase. The second phase is furthermore marked by migmatisation of basic and intermediate intrusives in a broad belt surrounding the southern part of the Big-feldspar granite.

The latest phase of granite development, mainly confined to the eastern part of the Julianehåb granite region, is marked by emplacement of leucocratic granites and passive remobilisation of older granites followed by intrusion of the net-veined diorites and leucocratic veining. Finally swarms of slightly metamorphosed tholeiitic dykes mark the transition from plutonic to cratogenic conditions.

Evidence is presented suggesting that the eastern part of the Julianehåb granite region constitutes the site of the latest thermal activity in the Ketilidian mobile belt. In addition differences in crustal conditions between this part and the surrounding regions during earlier stages of the plutonic evolution are considered.
\end{abstract}




\section{CONTENTS}

Page

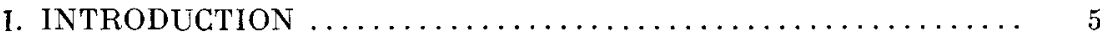

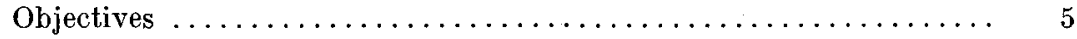

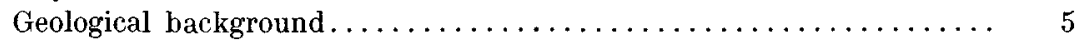

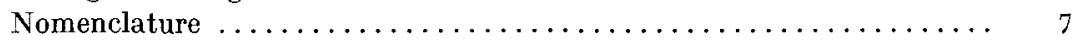

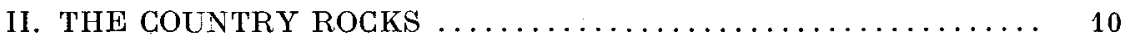

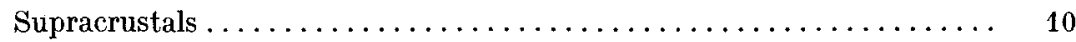

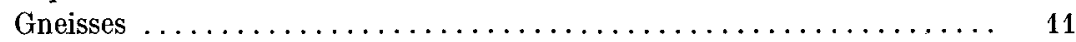

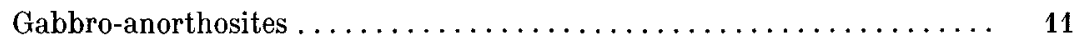

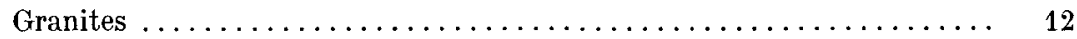

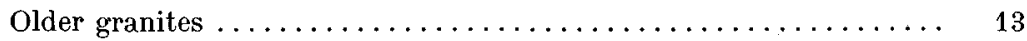

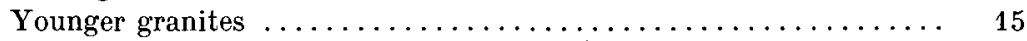

Structures............................... 18

III. SLIGHTLY METAMORPHOSED THOLEITTIC DYKES . . . . . . 20

IV. COMPOSITE NET-VEINED DIORITES ................ 22

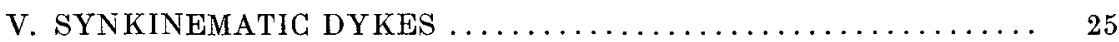

Form of the dykes ............................ 25

Mutual relations and internal structures.................. 27

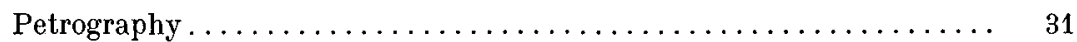

Relations to hot shear zones and leucocratic veins ............ 33

Relations of the synkinematic dykes to a regional stress field $\ldots \ldots \ldots \quad 39$

Other occurrences of possible synkinematic dykes $\ldots \ldots \ldots \ldots \ldots \ldots, \mathbf{4 1}$

VI. PYROXENE-BEARING DIORITES AND HORNBLENDITES.... 43

Occurrence and field relations.................... 43

Internal structures and microscopic observations $\ldots \ldots \ldots \ldots \ldots \ldots .44$

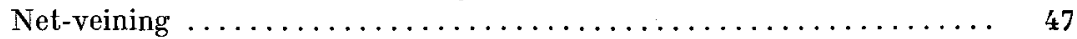

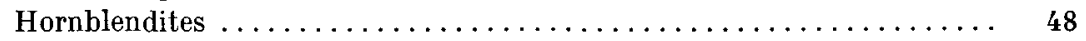

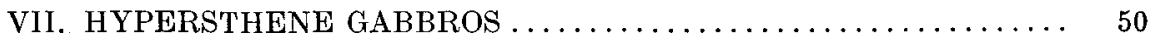

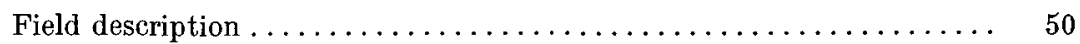

Microscopic observations ........................... 51

VIII. METADOLERITES AND ASSOGIATED BODIES ........... 5 4́

Primary features, field relations and distribution $\ldots \ldots \ldots \ldots \ldots \ldots \ldots .54$

Internal structures and microscopic observations . . . . . . . . 60

IX. CHEMISTRY OF SOME BASIC AND INTERMEDIATE INTRUSIVES 63

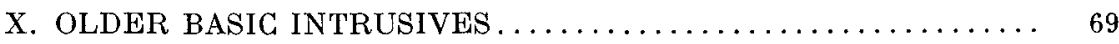

Possibilities of recognition of pre- or early orogenic dykes $\ldots \ldots \ldots \ldots 69$

The double-folded composite basic body along Bredef jord . . ....... 69

Double-folded discordant amphibolites in metamorphosed supracrustals

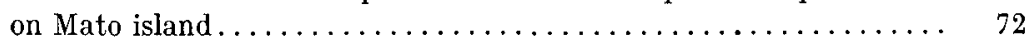

The metagabbro of Torssukátak fjord $\ldots \ldots \ldots \ldots \ldots \ldots \ldots \ldots \ldots \ldots$ 
XI. GHRONOLOGY AND GORRELATION................... 77

The procedure followed to build up the chronology ........... 77

The chronological relationships of the tholeiitic dykes and the latest

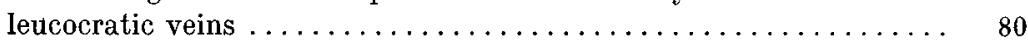

The chronology of Julianehåb peninsula . . . . . . . . . . . . . 81

The chronology of Pârdlît island and surroundings $\ldots \ldots \ldots \ldots \ldots \ldots 84$

The chronology of Avatarmiut and surroundings . . . . . . . . . . 91

The chronology of the outer parts of Bredef jord ............. 94

The chronology of Torssukátak fjord and surroundings $\ldots \ldots \ldots \ldots .95$

Correlation of the subareas . . . . . . . . . . . . . . . . . 97

XII. GRANITE DEVELOPMENT DURING THE 2ND EPISODE OF

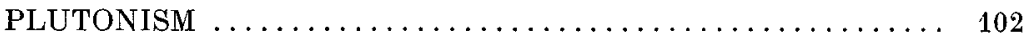

Distribution of granitic rocks predating the metadolerites ........ 102

Deformation, and emplacement of early 2nd episode allochthonous granites ................................. 103

The intrusion of the pyroxene-bearing diorites $\ldots \ldots \ldots \ldots \ldots \ldots \ldots 108$

The second phase of granite development ................ 109

The synkinematic dykes $\ldots \ldots \ldots \ldots \ldots \ldots \ldots \ldots \ldots \ldots \ldots \ldots \ldots \ldots$

The latest phase of granite development $\ldots \ldots \ldots \ldots \ldots \ldots \ldots \ldots, 112$

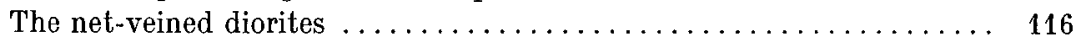

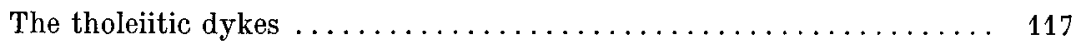

XIII. REGIONAL SETTING AND GORRELATION ............. 118

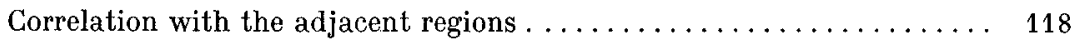

Considerations about the presence of pre-Ketilidian basement in the Julianehåb granite ......................... 119

Considerations about the crustal conditions within the Ketilidian mobile belt ................................ 120

The significance of the metadolerites (2nd period dykes) in South Greenland ............................... 124

Evaluation of the significant features of the basic and intermediate intrusives ............................ 126

Chemistry of some of the basic and intermediate intrusives $\ldots \ldots \ldots 128$

The development of the chronological terminology $\ldots \ldots \ldots \ldots \ldots \ldots 128$ 


\section{INTRODUCTION}

\section{Objectives}

Within the Precambrian basement of South Greenland there occurs an extensive area of relatively homogeneous granitic rocks known collectively as the Julianehåb granite (Ussing, 1912; AllaArt, 1964). This area, which occupies an asymmetrical position in the Ketilidian fold belt (WEGMAN , 1938), extends over about $125 \times 50 \mathrm{~km}$ between Kobberminebugt and Igaliko Fjord (see plate 2). Its north-eastern and southwestern limits are determined by the inland ice and the Davis Strait respectively.

During the summers 1961, ' 62 and ' 63 detailed investigations of various basic and intermediate intrusive bodies and their field relations were made in the eastern part of the Julianehåb district (see subsection nomenclature) between Qaersuarssuk and Igaliko Fjord. It is the purpose of the present paper to describe these bodies, to consider their distinguishing features and settings and moreover their relationships to the plutonic evolution of the Julianehåb granite. Finally the relationships of the granite to the other parts of the fold belt will be briefly discussed.

The various basic and intermediate intrusives are described in reversed chronological order.

\section{Geological background}

Between 1956 and 1963 members of the Geological Survey of Greenland (GGU) undertook systematic mapping of a cross section through the greater part of the Ketilidian fold belt between Ivigtut and Frederiksdal in South Greenland (plate 2). The work in the Ivigtut region, northwest of the Julianehåb district, resulted in the recognition of a preKetilidian basement (Ivigtut gneisses) which is separated by a major unconformity from the overlying Ketilidian sediments and volcanics (Bondesen, 1962). In the south-eastern part of the Ivigtut region the Ketilidian supracrustals and their basement were affected by regional 
metamorphism, granitisation and two phases of deformation (BONDESEN, in prep.; WINDLEY, et al., 1966).

In the Ilordleq area, south of Kobberminebugt (see plate 2) and on the north-western side of the Julianehåb district, WATterson (1965) has been able to establish a detailed chronology of important events which can be linked to the chronology of the Ivigtut region by means of the Ketilidian supracrustal rocks which can be traced from Grænseland towards the Kobberminebugt and surroundings (WEGMaNN, 1938). WATTERSON distinguished three episodes of basic dyking in the Julianehåb granite and adjacent supracrustals. The remnants of the oldest, termed the 1st period dykes, were correlated with the Ketilidian volcanics. Their emplacement was followed by folding and regional metamorphism of the Ketilidian supracrustals and the generation of Ketilidian granites (Julianehåb granite) in which pre-Ketilidian elements may still be incorporated. The 2nd period of basic dyking occurred after this first episode of plutonism. Both the 1 st and 2nd period dykes were considered to have been derived from basaltic material emplaced into cold crust. The dykes of the 3rd period of basic dyking were shown to have been intruded under plutonic conditions during the later stages of an episode of plutonism subsequent to the emplacement of the 2 nd period basic dykes.

To the south-east of the Julianehåb district a chronology similar to that in the Ivigtut-Ilordleq region has been established (EscHER, 1966, in press; PeRsoz, in press; WINDLEY, 1966 a). Ketilidian supracrustal rocks are well preserved in the S. Sermilik-Tasermiut region (plate 2). Transformed relicts of these can be followed towards the north-west up to Unartoq Fjord and possibly even to the Sârdloq area which lies off the south-eastern boundary of the Julianehåb granite. During an early episode of plutonism two phases of deformation $\left(\mathrm{F}_{2}\right.$ and $\mathrm{F}_{3}$ of Escher, 1967) produced major folds on a regional scale. During and after the second phase migmatisation and granitisation took place. In the region to the west of Unartoq Fjord this was followed by a temporary retreat of the geo-isotherms and by intrusion of numerous swarms of thin dolerite dykes. These were metamorphosed and deformed during a subsequent episode of plutonism after the first stages of which two generations of major granite bodies were emplaced in close connection with basic and intermediate intrusive bodies. The youngest of these generations corresponds to the "New granite" suite of BRIDGWATER (1963). In the area north of Unartoq Fjord (PERsoz, in press) still younger major granite bodies postdate important concentrations of dykes with the same setting as the plutonic 3rd period dykes from the Ilordleq area.

Throughout the region between Ivigtut and Frederiksdal the Ketilidian plutonism is postdated by high-level faulting, sedimentation 
of continental sandstones, volcanism, basic dyking and alkaline igneous activity (Gardar period) the main centres of which occur in the eastern part of the Julianehåb district.

\section{Nomenclature}

Chronological nomenclature. In the present paper the naming of part of the time division of the Precambrian of South Greenland will be different from the GGU standard nomenclature of the last few years (see table 1). The reasons for this will be discussed in the final section. The difference involves abandonment of the terms Kuanitic and Sanerutian. Accordingly the Ketilidian is redefined as the period between the start of the deposition of the sediments of the Grænseland and S. SermilikTasermiut areas, and the beginning of the sedimentation and the alkaline igneous activity of the Gardar period. The Ketilidian period is subdivided as follows. A phase of sedimentation, volcanism and basic dyking is followed by two episodes of plutonism. In the region between Unartoq Fjord and Kobberminebugt a break between the two episodes is marked by intrusion of basic dykes. In the eastern part of the Julianehåb district three phases of granite development can be distinguished during the 2nd episode of Ketilidian plutonism, but elsewhere in general two. The terminology of the pre-Ketilidian is adopted from the results of recent work in South and West Greenland outlined by HigGiNs and Bondesen (1966) and by WiNdLey et al. (1966). This also concerns the eastern part of the Julianehåb district as it is probable that here there are rocks which can be correlated with pre-Ketilidian rocks occurring to the northwest of the Julianehåb district.

It should be noted that the span of time regarded as Ketilidian by Berthelsen (Berthelsen and Noe-Nygaard, 1965, table 26) corresponds with part of the time called pre-Ketilidian in table 1.

Foliation is used to denote the property of a rock, fine-, medium- or coarse-grained, in which more or less closely spaced planar elements can be recognised, mainly defined by preferred dimensional orientation of mineral grains.

The term granite is always used in a wide sense, covering foliated and unfoliated rocks which range in composition from granite s. str. to quartz diorite.

The term hot shear zone is used to indicate thin zones of movement in which destruction of the minerals of the deformed country rock took place together with slight recrystallisation. Microscopic observations show that hornblende and biotite remained stable during the deformation suggesting that the country rock was not cold when the zones originated. These zones could as well be called hot mylonites emphasising the de- 
Table 1.

The chronological terminology used in this paper. The dates between brackets are according to suggestions made by BRIDGWATER (1965).

\begin{tabular}{|c|c|c|}
\hline Time & Events & $\begin{array}{c}\text { GGU standard } \\
\text { nomenclature } \\
(1962-1965)\end{array}$ \\
\hline Gardar & $\begin{array}{l}\text { Alkaline igneous activity, dyking, faulting; } \\
\text { Sedimentation of continental sandstones } \\
\text { (ca. } 1,450 \mathrm{~m} . \mathrm{y} .)\end{array}$ & Gardar \\
\hline \multirow{3}{*}{ Ketilidian } & $\begin{array}{l}\text { Intrusion of tholeiitic dykes } \\
\text { 2ND EPISODE OF PLUTONISM } \\
3 \text { phases of granite development, } \\
\text { reactivation of older granites; repeated } \\
\text { intrusion of basic to intermediate } \\
\text { igneous rocks } \\
\qquad, 655 \text { m.y. }\end{array}$ & Sanerutian \\
\hline & $\begin{array}{l}\text { Dolerite intrusion in and around Julianehåb } \\
\text { granite }\end{array}$ & Kuanitic \\
\hline & $\begin{array}{l}\text { 1ST EPISODE OF PLUTONISM } \\
\text { (ca. 1,700-1,900 m.y.) } \\
\text { plutonic activity, regional metamorphism, } \\
\text { repeated deformation } \\
\text { Sedimentation, volcanism, basic dyking } \\
\text { (ca. } 2,000 \text { m.y.) }\end{array}$ & Ketilidian \\
\hline \multirow[t]{3}{*}{ Pre-Ketilidian } & $\begin{array}{l}\text { Basic dyking } \\
\text { Plutonism, regional metamorphism, } \\
\text { repeated deformation } \\
\text { (ca. 2,500 m.y.) }\end{array}$ & \multirow[t]{3}{*}{ Pre-Ketilidian } \\
\hline & Sedimentation, volcanism (Tartoq Group) & \\
\hline & Older basement (part of Ivigtut gneisses?) & \\
\hline
\end{tabular}

struction of the deformed rock. However, since it is necessary to emphasise that they were formed at an elevated temperature in the crust under plutonic conditions the term hot shear zones is preferred and will be used in the following text.

Julianehåb district designates the whole area of Julianehåb granite (see plate 2).

The terms plutonism and plutonic rocks are used in the sense of READ (1957).

Porphyritic texture indicates a texture of some rocks without any implication about the state of the host rock during the formation of this texture. 
Relict dykes. This term is used a few times to describe basic dykes which have been intruded into granitic terrain after a major phase of migmatisation, and whose characteristics (similar to those of the metabasaltic dykes of Sederholm, 1926) are due to renewed plutonism.

Synkinematic dykes (see section V). In contrast to common usage the word synkinematic is used in this context to describe those dykes that can be shown to have been intruded into active hot shear zones, or at least intermittently with stress into country rocks which were still at an elevated temperature during certain stages of the plutonic evolution of the crust. 


\section{THE COUNTRY ROCKS}

\section{Supracrustals}

Supracrustal rocks are not uncommon in the area investigated. Some of the inclusions and relict bands in the Julianehåb granite are recognisable as of this origin. Some are quartzitic and have occasional cross-bedding, while others are amphibolitic in composition and have well preserved bedding, but their true origin is usually not clear.

In the gneisses there are commonly bands of quartzitic rocks. In a few areas, for instance on Julianehåb peninsula, layers of pure quartzite up to a few tens of metres wide can be followed for considerable distances. Graded bedding and cross-bedding are often seen. In most cases these rocks are slightly feldspathic, and some mica is usually present. Transitions to semipelitic schists and gneisses occur frequently.

Amphibolitic rocks of calcareous origin are rare. Other amphibolitic rocks seem to be more tuffitic in character and they usually have a marked banding defined by variation in the relative amount of hornblende and plagioclase. Megacrysts of euhedral to subhedral plagioclase, a few millimetres in size, commonly occur, as well as aggregates of hornblende, which are usually rich in ore minerals, but are surrounded by a rim of green hornblende free of opaque inclusions. The aggregates are obviously pseudomorphic. Quartz is present in the feldspathic layers. Agglomeratic structures have not been observed. On Mato island and a few surrrounding small islands these banded amphibolites show very pronounced graded and cross-bedding. They form a zone several tens of metres thick overlying a much thicker zone of homogeneous amphibolitic rocks (with hornblende aggregates), the base of which is not exposed. In the zone of banded amphibolitic rocks there are some horizons of quartzitic rocks.

The metamorphosed supracrustals within a relatively large area surrounding Mato island occur either as bands in the gneiss or as large, elongate concentrations of oriented inclusions in the granite. The granitisation phenomena of the supracrustals have been investigated in some detail on the south-west part of Julianehåb peninsula and on Pârdlît where it has been possible to establish an extensive succession of events. 


\section{Gneisses}

Feldspathic gneisses occasionally form isolated bands which can be followed for considerable distances and also zones of inclusions and small elongate areas, but very rarely are there isolated inclusions of gneiss. In some areas gneiss bands regularly alternate with conformable zones of granite, for example along the outer parts of Bredef jord and the south-eastern part of Igaliko peninsula. On Julianehåb peninsula a broad ENE-trending zone of gneiss and intercalated supracrustals has been mapped by NesBITT (1961). This zone can be followed for at least $15 \mathrm{~km}$. The gneisses are usually fine-grained, consisting of plagioclase $\left(A n_{20-30}\right)$, some quartz and hornblende, biotite and epidote. Bands rich in the mafics just mentioned occur regularly and usually outline the fold structures. Here and there bands rich in biotite grade into pelitic varieties. No aluminium silicates have however been observed. Zones and bands of massive amphibolite occur frequently in places, but their original character is difficult to define.

The gneisses are locally folded with their intercalated granite bands. In places the gneiss is penetrated by granite zones coming from the country rocks and these are also folded.

\section{Gabbro-anorthosites}

Gabbro-anorthositic rocks occur in three places in the area investigated. Along the north-eastern side of Akugdlitt nunât in the Big-feldspar granite they form layers of several tens of metres width which can be followed for long distances in the direction of the foliation of the country rock. Along Torssukatak f jord they form bands intercalated with bands of granite and gneiss. Finally on a small island south-east of Niaqornap nunâ not far from the south-eastern contact of the Big-feldspar granite a large number of inclusions of these rocks occur (see plate 2).

The gabbro-anorthositic rocks consist mainly of plagioclase while the quantity of the mafics, hornblende and biotite, varies between 20 and $30 \%$ of the rock volume. Foliation is marked by the orientation of mafic minerals or their aggregates and by the orientation of lenses of finegrained plagioclase with a length of 2 to $3 \mathrm{~cm}$.

In the occurrences of Akugdlit nunât the plagioclase crystals are sub- to anhedral, average $4 \mathrm{~mm}$ in length and are usually homogeneous $\left(\mathrm{An}_{\mathbf{3 0}}\right)$; only very locally do more basic relicts occur. Antiperthitic inclusions of microcline are frequent. Some of the crystals show polysynthetic albite twinning, the lamellae of which are very thin. Along the grain boundaries of the larger crystals there are frequently fine-grained aggregates of equidimensional plagioclase grains a few tenths of a 
millimetre in size. The hornblende is olive green in colour and forms either large subhedral crystals or smaller grains concentrated in aggregates together with biotite which has largely been replaced by optically negative penninite. Besides the antiperthitic inclusions, microcline forms irregular, interstitial grains and also large, regularly distributed porphyroblasts. Accessories are quartz, brown titanite, ore and orthite which is usually very fresh and rimmed by epidote.

The gabbro-anorthosite from Torssukátak fjord is slightly richer in mafics and in biotite than the rock just described. The plagioclase forms a fine-grained aggregate of equidimensional grains $\left(A n_{25}\right)$ a few tenths of a millimetre in size in which anhedral megacrysts of plagioclase, 1 to 3 $\mathrm{mm}$ in size, with irregular outlines are preserved. In the megacrysts there are relict parts which occasionally reach an An content of $45 \%$.

The relatively large grain size, the widespread antiperthitic textures in the plagioclase and the local occurrence of plagioclase relicts of more basic composition distinguish these rocks from the typical fine-grained gneisses and supracrustal rocks from the area investigated. It is however evident that recrystallisation and metasomatism have had a considerable influence in the history of the rocks as is shown by the widespread tendency of plagioclase to form fine-grained aggregates and the frequent occurrence of microcline megacrysts.

It is tempting to make a long distance correlation with the gabbroanorthosites from the Ivigtut region which form part of the pre-Ketilidian basement. However, more detailed information is needed to prove this.

\section{Granites}

The Julianehåb granite is variable in appearance. This variability is marked by: variations in composition on the scale of the exposure as well as on a regional scale; variability of the proportions of gneiss bands in relation to granite and of generally oval-shaped inclusions mainly consisting of amphibolitic rocks; variations from coarsely porphyritic to finely porphyritic granite and from very porphyritic to slightly or non-porphyritic granite. Most of the Julianehåb granite is medium- to coarse-grained except the Redekammen type of granite which is mediumor medium- to fine-grained.

Six main varieties can be distinguished. In three of these, to be described first, the main phases of crystallisation are considered to have taken place during the 1st episode of Ketilidian plutonism. They generally seem to have remained autochthonous. The members of the three younger varieties originated respectively during successive stages of the 2 nd episode of plutonism, although there might have been considerable 
overlap. Except for some parts of the Big-feldspar granite these younger varieties seem mainly to be allochthonous. The observations showed that large parts of the older granites were strongly reconstituted during the 2nd episode of Ketilidian plutonism.

The criteria used for the classification into autochthonous and allochthonous members of the granite series are: 1) continuity of gneiss bands; 2) preservation of medium and large scale structures; 3) spacing and distribution of fragments of disrupted basic dykes which give important indications about the setting of the younger granites.

\section{Older granites}

1. Nebulitic series of granite and gneiss. Although the nebulitic series cannot be considered as a proper variety it is still treated as such since it is mainly distinguished by its setting when compared to other varieties of granites. Moreover it can constitute relatively large areas, viz. around the outer parts of Bredef jord (Upton, 1962; WatT, 1965) and the south-eastern part of Igaliko peninsula. Along Torssukatak f jord the nebulitic series occurs in the limbs of an antiformal structure the core of which consists of a homogeneous and relatively leucocratic granite (variety 4).

In these areas bands of granite, gneiss and amphibolitic rock alternate regularly, the granite generally predominating over the other rock types. The granite is variable in character and composition. Relatively mafic bands of granite are rich in basic inclusions, while relatively leucocratic granite can be rich in inclusions of quartzitic gneiss, so that it appears that the composition of the granite is dependent on the original composition of the parent rock.

The nebulitic series is considered to represent the oldest, autochthonous member of the granitic series in the area investigated and it even contains elements believed to be pre-Ketilidian, e.g. gabbroanorthositic rock and, in one locality, the granitic country rock around a possible preorogenic dyke relict (section $\mathrm{X}$ ). The observations showed however (section XII), that considerable reconstitution took place during the 2nd episode of Ketilidian plutonism, but that the rocks remained autochthonous as is shown by the continuity of the metadolerites which predate the 2nd episode.

2. Foliated porphyritic hornblende-biotite granodiorite. This variety is relatively mafic and medium- to coarse-grained. Hornblende and biotite constitute 20 to $40 \%$ of the rock volume. The granodiorite is porphyritic to very porphyritic; the length of the megacrysts is usually not more than $3 \mathrm{~cm}$ and they are generally well oriented. Small lenticular inclusions 
are very frequent. Almost without exception they are made up of fine- to medium-grained amphibolitic rock. A foliation is marked by the orientation of the dark minerals, the inclusions and the microcline megacrysts. The composition of the granodiorite can be slightly variable; alternating bands of relatively leucocratic granodiorite, with few inclusions, and melanocratic granodiorite with abundant inclusions occur ranging from less than a metre to several tens of metres in width. Generally these are parallel to the foliation, but occasionally where the bands are folded the foliation is parallel to the axial planes of the folds.

This variety occurs in close association with the nebulitic series and occupies most of the south-eastern part of Igaliko peninsula. It is identical to the so-called homogeneous gneisses from Sârdloq (WindLey, 1966) and is similar to banded coarsely porphyritic granodiorite exposed in the outer parts of Bredef jord and referred to variety 2. In this granodiorite, however, the microcline megacrysts are identical to those of the Bigfeldspar granite (variety 5).

Variety 2 remained largely autochthonous during the 2nd plutonic episode, as is shown by the field relations of the metadolerites which predate this episode. The fact that variety 2 is so closely associated with the nebulitic series might indicate that it obtained its granitic character during the 1st plutonic episode of Ketilidian plutonism, but no evidence can be given from the area investigated to support this. In the Sârdloq area at the south-eastern border of the Julianehåb district where this variety is also exposed WindLeY (1966) showed that the intensity of plutonism during the 2 nd episode was so weak that the microcline megacrysts there may safely be considered as of 1st episode age. Whether or not the evidence valid for the Sârdloq area is equally valid for the eastern part of the Julianehåb district remains a matter of opinion.

3. Mafic hornblende-biotite granodiorite. The rock is medium-grained, mafic in composition and fairly homogeneous. Hornblende is the main dark mineral, although biotite is ubiquitous in varying amounts. Foliation is marked by the orientation of the mafic minerals and of the basic inclusions which are very frequent. The frequency of the inclusions is variable. In some places zones rich in inclusions alternate with other zones poorer in inclusions. Occasionally the mafic granodiorite is slightly porphyritic. The microcline megacrysts measure 1 to $2 \mathrm{~cm}$; they have a random orientation. Here and there there are bands of gneiss which can be followed for considerable distances. The mafic granodiorite is exposed over the greater part of Qarmat land (ScharberT, 1958) and also on the peninsula to the south-west, where the foliation has the form of a broad synformal structure with a NW-trending axis. Still more to the southwest medium and large scale structures have been recorded with NW 
and NE trends. These structures, which are interpreted as old relict structures formed by repeated deformation on a regional scale, seem to continue far into the Big-feldspar granite to a small area where thick bands of gabbro-anorthositic rocks have been preserved. This might indicate that variety 3 is also autochthonous. However, on a local scale phenomena of mobility have been recognised in a few places.

\section{Younger granites}

4. Porphyritic to slightly porphyritic biotite-hornblende granodiorite to adamellite. Due south of Lille Tugtutôq, on Pârdlitt and surroundings, on the south-eastern part of Julianehåb peninsula, on part of Igaliko peninsula and around Torssukátak fjord, granitic rocks which show many similarities to all the above varieties are exposed, but they are generally more homogeneous and less mafic in composition. They vary from medium- to coarse-grained and from granodioritic to adamellitic. Microcline crystals are usually bigger than those of plagioclase. Biotite, and also hornblende, occur in varying amounts, but they usually constitute between 10 and $25 \%$ of the rock volume. The granite is generally porphyritic to slightly porphyritic; the length of the microcline megacrysts is usually not more than $3 \mathrm{~cm}$. A weak foliation is commonly displayed and is marked by the orientation of the dark minerals or of the inclusions. The inclusions are widespread, but generally less frequent than in the varieties described above.

The most important body of this variety is exposed on the southeastern part of Julianehåb peninsula and on part of Igaliko peninsula. Its longitudinal axis is parallel to the regional structures and it is probable that the emplacement of the body was controlled by pre-existing structures in the crust. This is supported by the fact that the gneiss band from Julianehåb peninsula extends from the south-west and reappears more to the east on Igaliko peninsula and the north-eastern part of Arpatsivik apparently describing a closure of a major fold (see plate 3). Moreover, observations on cross-bedding and graded bedding in sediments at the south-eastern side of the gneiss band of Julianehåb peninsula seem to indicate that they young towards the north-west. It is therefore tempting to conclude that the granite body originated in an antiformal structure which was broken through when the body began to move upward. On Julianehåb peninsula the body has a 2 to $3 \mathrm{~km}$ wide marginal facies of slightly or non-porphyritic granodiorite in which great numbers of inclusions of gneiss, supracrustal rocks and disrupted doleritic dykes occur. Farther into the body the rock is porphyritic and it contains scattered oval-shaped inclusions of strongly recrystallised amphibolitic rocks in which no original structures can be recognised. 
In section XII evidence will be presented suggesting that this variety became allochthonous during the early stages of the 2 nd episode of Ketilidian plutonism. At the same time it will be argued that it is probable that at least on Pârdlitt and surroundings the country rock was already granitic before the beginning of the 2 nd episode.

5. Coarsely porphyritic granodiorite (Big-feldspar granite). An extensive body of Big-feldspar granite comprises large parts of Tugtutôq (UPToN, 1962) and the area north of Bredefjord. In addition relatively small areas of this granite have been observed on Qaersuarssuk (WATT, 1965) and on Lille Tugtutôq in close association with the nebulitic series.

The matrix of the rock, medium- to coarse-grained and granodioritic in composition, is relatively mafic and may be identical in appearance to any of the varieties described above. In the main body it is generally homogeneous. On Qaersuarssuk and Lille Tugtutôq banding, probably inherited from variety 2 , is widespread. Euhedral to anhedral megacrysts of microcline, usually averaging $4 \mathrm{~cm}$ with a maximum of $8 \mathrm{~cm}$, occur in considerable but varying amounts. They show a preference to crowd in and around basic patches and schlieren and in relatively large inclusions. Some megacrysts show an augen form suggesting that they originated contemporaneously with the formation of the foliation or were even earlier in age.

The foliation in the major body usually trends NE to ENE, but in its north-western part major folds with NW-trending axes occur. As far as can be seen the structures in the surrounding Julianehåb granite continue without a break through the body. A sheet form for this Big-feldspar granite body cannot be excluded.

North of Bredef jord the eastern contact is steep and transitional. On approaching the Big-feldspar granite from a distance of about 50 to $100 \mathrm{~m}$ the first features to be seen are small microcline megacrysts, $1 \mathrm{~cm}$ in size, which gradually increase in size and number towards the contact until typical coarsely porphyritic granodiorite is developed. The matrix of the rock is slightly coarser than the adjacent mafic granodiorite (variety 3 ), suggesting that the matrix recrystallised to some extent during the growth of the megacrysts.

In most other places the contact of the Big-feldspar granite dips shallowly or moderately and along its western side it dips inwards. It is usually distinct and marked by the sudden appearance of the large microclines. Not far outside the main contact lenses and layers of Bigfeldspar granite are frequent.

The relations of the big feldspars in the banded granite, which forms bands in the nebulitic series along the outer parts of Bredef jord, indicate that they postdate the deformation which operated during the 
early stages of the 2nd episode of Ketilidian plutonism. Evidence to be given on p. 106 might suggest that the big feldspars along the outer parts of Bredefjord originated at the expense of the pre-existing smaller megacrysts of variety 2 . There are no indications that this suggestion has any validity for the main body of Big-feldspar granite. Observations at the south-west and west side of the body show that there the formation of the big feldspars postdates allochthonous granite belonging to variety 4 , probably early 2 nd episode in age, and also a group of diorite bodies which are later than variety 4 . The preservation of large scale fold structures in the north-west part of the granite body suggests that at least part of it is autochthonous. The presence of relict bands of gabbroanorthositic rocks might indicate that the parent rock in that part is extremely old. Chronological considerations, to be dealt with in section XI on chronology, make it probable that the Big-feldspar granite is of similar age as the members of the "New granite" suite (Bridgwater, 1963).

6. Leucocratic granites of Redekammen type. These are fine- to medium-grained, slightly porphyritic granites, briefly described by AllaArt (1964). Microcline megacrysts reach a maximum length of 1.5 $\mathrm{cm}$. The biggest bodies seem to have diapiric characteristics while others have a sheet form.

The most important body of this variety, which consists of homogeneous granite almost devoid of any inclusions, is exposed on the northwest part of Igaliko peninsula and on Arpatsivik. Its longitudinal axis is parallel to the regional structures and it is almost completely surrounded by allochthonous granite of variety 4 (see plate 3 ). The contacts of the body are generally steeply inwardly dipping, although along its southeastern side the contact is flat-lying for a distance of $4 \mathrm{~km}$.

On Qarmat land north of Bredefjord, a body which has been classified as belonging to the Redekammen type shows similar relations to the surrounding structures as the body just described. The longitudinal axis of the Qarmat body lies however in a NW-SE direction which corresponds with the main trend of major structures to the south-west of it. The presence of a broad synformal structure immediately southwest of the body suggests that its place is controlled by an earlier antiformal structure. The central part of the Qarmat body consists of leucocratic medium-grained granite which contains numerous disoriented inclusions of acid gneiss and amphibolitic rocks. This and the presence of numerous fragments of basic dykes which were disrupted and torn far apart, suggest that the granite was mobile and not autochthonous. Along the whole margin of the body there is a broad zone of fine-grained, aplitic granite, which is almost devoid of inclusions and which veins the 
surrounding mafic granodiorite (variety 3). There is a very gradual transition between the mobile granite and the aplitic granite. The difference in field appearance between these two leucocratic granite varieties and the large width of the aplitic marginal zone does not support the concept that the latter is a chilled margin of the mobile granite in the core of the body. The age of the granite body is not known. It is very well possible that the core granite became intrusive during the early stages of the 2nd episode of plutonism or even much earlier.

Phenomena similar to those observed in the Qarmat granite body were recorded to the north-east of Torssukátak fjord where a very broad mantle of very homogeneous aplitic granite surrounds the north-eastern part of an area of relatively leucocratic granite (variety 4), part of which occupies the core of an antiformal structure in the nebulitic series. The broad aplite mantle veins the adjacent Big-feldspar granite (variety 5) occurring towards the east. It is therefore clear that the aplite granite originated considerably later than the granite (variety 4) in the core of the antiformal structure. After the formation of the aplite mantle a suite of late-plutonic intermediate sheets and dykes were intruded into the core granite, the nebulitic series and in the lower part of the mantle. Subsequently the sheets and dykes were disrupted as a result of slight remobilisation in the country rocks.

The age relations of the Redekammen type granite to the Bigfeldspar granite are established by the occurrence of a circular body of the former penetrating the latter in the centre of Tugtutôq island. The relations of the Redekammen body of Igaliko peninsula and two other smaller granite bodies to various plutonic basic and intermediate intrusive bodies, to be dealt with in section XI, show that the emplacement of the Redekammen type granites was the latest major plutonic event in the eastern part of the Julianehåb district.

\section{Structures}

In the area between Bredef jord and Igaliko Fjord the foliation and other planar elements have a predominant NE trend and are steep or vertical. In some areas, as for instance in the outer parts of Bredef jord, low-dipping attitudes are common. South-west of Qarmat land the main trend of the structures is NW-SE.

In several localities where gneisses and supracrustals are exposed a succession of deformation phases has been distinguished, producing different sets of folds (see also section X). It was possible to recognise two phases of folding of 1st episode age, with trends NE and NW, and a phase with NE trends taking place during the earlier stages of the 2nd episode of Ketilidian plutonism. The observations are however too 
isolated for it to be possible to give a complete picture of the succession of deformation phases. Only with the more complete evidence from the areas more to the north-west (Bondesen, in prep; Higgins and BondeSEN, 1966; Watterson, 1965) and to the south-east (Escher, 1966; Persoz, in press; Windley, 1966 b) can the observations concerning deformation phases and deformed basic dykes be reliably interpreted.

As has been shown before, the emplacement of some granite bodies during the 2nd episode of plutonism appears to be closely controlled by older major fold structures. The clearest example can be given in the area between Julianehåb and Igaliko peninsulas where the presence of a large antiformal structure has been deduced (p. 15). Its north-western limb is marked by the gneiss band of the Julianehåb peninsula and its south-eastern limb by an ENE-trending zone with numerous gneiss relicts on Igaliko peninsula (variety 1). The core of this probable antiform is not only occupied by the Redekammen granite body but also by an allochthonous granite (variety 4), early 2 nd episode in age. There are thus two phases of granite emplacement, and maybe even an older one, which can be recognised in this fold core. It is impossible to indicate how close the connection is between the two later phases of intrusion. The field relations of a suite of basic to intermediate dykes, to be described in section $\mathrm{V}$, show that the earlier granite (variety 4) was solid before the Redekammen body was emplaced.

The relations of the Qarmat granite body to the surrounding structures and granites permit some speculations about the ghost stratigraphy in the area investigated. This body appears to pierce through mafic granite (variety 3) which probably originated from a series of basic rocks at least $600 \mathrm{~m}$ thick. The numerous acid gneiss inclusions in the core of the body suggests that originally the basic parent rock of the mafic granite was underlain by a series of quartz-rich sediments. It is not possible to determine the age of this succession. The occurrence of an important area of mafic granite (variety 2) on Igaliko peninsula on the south-eastern limb of the large antiformal structure mentioned above, which contains the same type of granite in its core as that of the Qarmat body, might suggest that in this area there is another relic of basic parent rock which might be correlated with that of Qarmat land. 


\section{SLIGHTLY METAMORPHOSED THOLEIITIC DYKES}

There are several swarms of NW-trending basic dykes more or less regularly distributed over a $20 \mathrm{~km}$ wide zone running in a north-western direction from the western point of Akia to the inland ice. Their colour is bluish green and this contrasts clearly with the dolerites of Gardar age which are brown or black in colour. The width of the dykes averages $1 \mathrm{~m}$, the thickest being $20 \mathrm{~m}$ wide.

Under the microscope relict ophitic texture is well displayed. The main constituents are hornblende and plagioclase which occur in equal proportions. Pyroxene occurs occasionally and ore and apatite are accessories. Plagioclase is strongly zoned with basic cores up to $\mathrm{An}_{52}$. The acid rims show a light brown colour which is possibly due to pigmentation. Pyroxene forms relicts in a light bluish green hornblende which in places is filled with finely divided ore. In the thickest dyke of this group there is hypersthene, usually rimmed by clinopyroxene. Parts of these minerals are replaced by a colourless asbestiform hornblende which shows polysynthetic twinning and has thin rims of bluish green hornblende. Small areas of granophyric intergrowth of acid plagioclase and quartz are common in all the dykes. The margins of the thicker dykes are very fine-grained and consist of actinolitic hornblende and strongly sericitised plagioclase. They are clearly the result of chilling. In a few places where the margins are sheared biotite flakes which are oriented parallel to the contacts of the dykes occur regularly distributed.

Petrographically similar dykes, also trending NW, occur in the Grænseland and Sydprøven areas (Bondesen, in prep; Persoz, in press; D. Bridgwater, personal communication). The dykes of these areas respectively occur due north-west and due south-east of the zone between Akia and the inland ice and evidently constitute the continuation of the swarms of that zone.

No traces of migmatisation of the dykes by the country rock granite have been observed. They intersect representatives of all of the basic 
and intermediate intrusives to be described in the following sections and also late leucocratic veins in numerous localities throughout the area investigated. These tholeiitic dykes have however been slightly metamorphosed. They have been displaced by Gardar faults. In the Sydprøven area they are cut by the oldest generation of Gardar dykes in that area. Similar relations were reported from the Grænseland area. Thus the dykes are regarded as marking the last pre-Gardar event, emplaced shortly before regional metamorphism finally ceased in this part of Greenland. 


\section{COMPOSITE NET-VEINED DIORITES}

For a complete description and a critical discussion of the origin of these intrusive bodies and their regional distribution the reader is referred to WindLEY (1965). In the present paper their internal structures and their field and chronological relationships will be briefly treated. In addition a few suggestions will be made as to the possible origin of the net-veining.

The net-veined diorites are very regularly distributed throughout the area between Bredef jord and Igaliko Fjord. They form a fracture filling system in which flat or low-dipping sheets strongly predominate over vertical dykes. On a few islands off the western side of Akia there are multiple sheets in which the emplacement of the diorite took place in two closely spaced phases. The diorite of the earlier phase is basic (called "meladiorite" by WindLeY, 1965) and very rich in plagioclase phenocrysts, and phenocrysts and aggregates of hornblende. That of the second phase is clearly less basic, but may contain a great deal of plagioclase and hornblende megacrysts and hornblende aggregates, most of which have been derived from the meladiorites. In the area studied all the diorite in the net-veined intrusives belongs to the second phase. It is possible that meladiorite was intruded in some places, and that it was entirely taken up and resorbed by the second phase. Large clouds of plagioclase and hornblende xenocrysts (?) and hornblende aggregates in some sheets provide the only indications that there has been meladiorite.

Generally the margins of the sheets and the dykes have been replaced by a leucocratic granite or aplite clearly differing from the country rock granite. From these margins veins penetrate the inner parts of the bodies forming a network which divides the diorite into pillow-shaped blocks (fig. 1). The amount of replacement of the diorite by the aplite of leucocratic granite is variable. This is clear not only on the scale of large exposures but also on a regional scale. For instance in the sheets in the south-eastern part of Julianehåb peninsula the aplitic material predominates in some places to such a degree that for long stretches no diorite or only a few inclusions occur. On Lille Tugtutôq however the net-veins are clearly less predominant. It is noteworthy that on Juliane- 


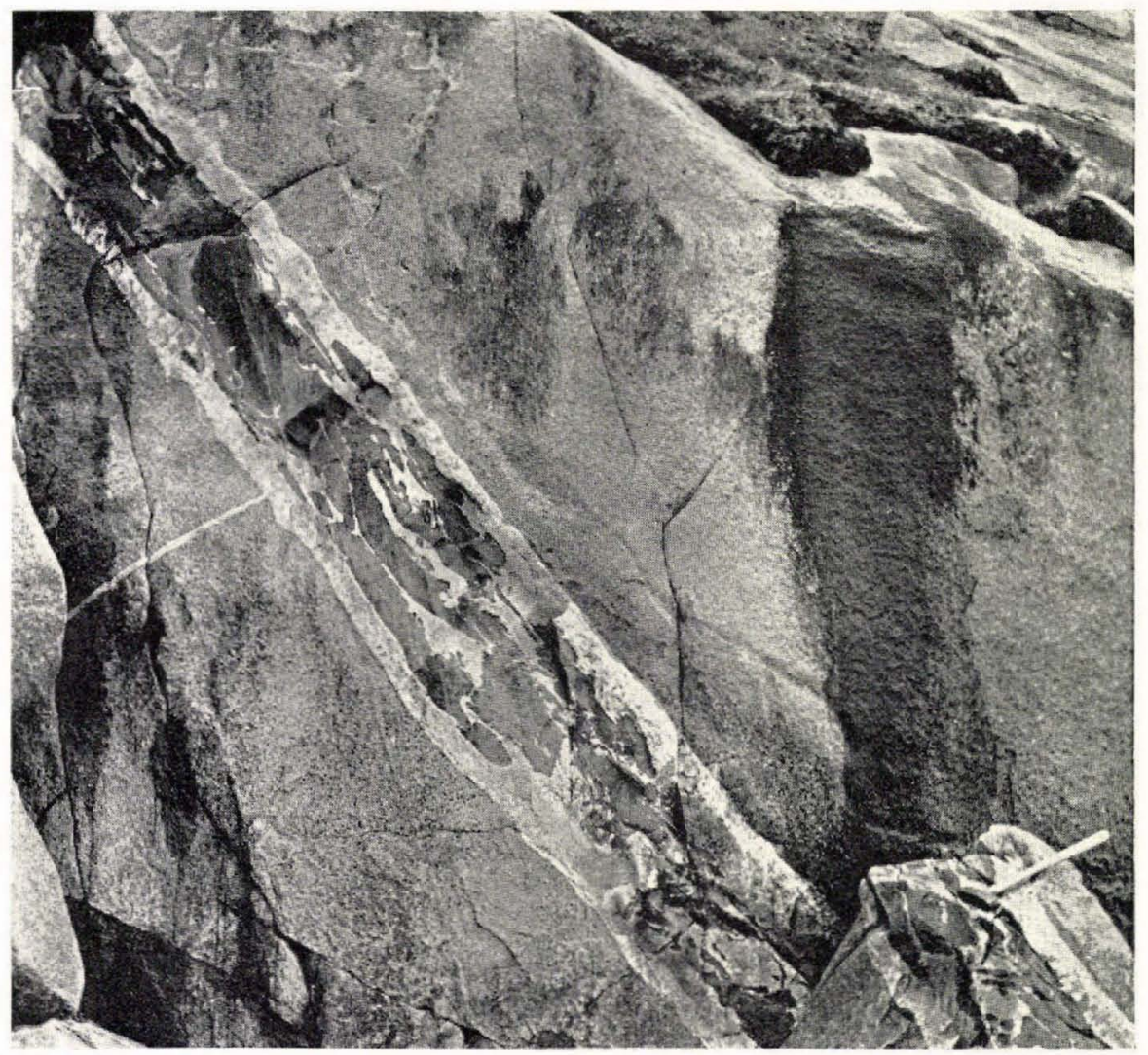

Fig. 1. Net-veined diorite sheet crosscutting pyroxene-bearing diorite body. Avatarmiut.

håb peninsula leucocratic veins in the country rock granite are much more frequent than on Lille Tugtutôq. It could be shown that these leucocratic veins have a similar chronological position as that of the diorites (see pp. 80,81,116). It is possible therefore that there is a relation between the frequency of leucocratic veining in the country rock and the degree of net-veining in the diorite.

The chronological relations of the net-veined diorites (section XI) suggest that the emplacement of the diorites and the formation of their granitic net-veins are very closely connected.

The net-veined diorites are generally undeformed. Occasionally thinner sheets or dykes have an internal foliation which is slightly oblique to their margins or sigmoidal in shape. These internally deformed bodies are usually offshoots of bigger sheets or dykes which show no sign of deformation.

Some of the multiple meladiorite sheets off Akia crosseut the struc- 
tures in the country rock at an angle of $20^{\circ}$ to $30^{\circ}$. The bodies have an internal foliation oblique to their contacts, but parallel to the foliation in the host granite. In one locality two leucocratic veins, belonging to different generations, crosscut the meladiorite sheet. In the country rock they are straight; as soon as they enter the diorite body they are folded and boudinée. The net-veins are also folded and the internal foliation follows the axial planes of the folds. The internal deformation postdates the multiple intrusion, the formation of the net-veins and two generations of leucocratic veins. Similar features will be described from the synkinematic dykes in the following section.

As WindLey (1965, plate 1) has shown, the net-veined diorites form a dense network of sheets and dykes occurring in an almost complete garland around an oval-shaped area with an ENE-trending longitudinal axis running from Qagssimiut to Narssarssuaq. The absence of intersections between net-veined diorites combined with the high density of the bodies suggests that they are all contemporaneous.

Except in the Redekammen type granites (variety 6) there are no signs of migmatisation or fragmentation of the net-veined diorites by any of the main varieties of Julianehåb granite. This is especially clear in the southern part of the main body of Big-feldspar granite (variety 5), where several widely scattered bodies of net-veined diorite truncate the microcline porphyroblasts and it is evident that generally the country rock granite was practically dead, although not yet cold, when the diorites were intruded. At the southern side of Avatarmiut and also on Arpatsivik immediately east of Julianehåb peninsula several continuous sheets of net-veined diorite proceed from the surrounding granites and crosscut two of the bodies of leucocratic granite of Redekammen type. In the latter the sheets remain completely continuous, but occasionally thin veins of the host granite penetrate the diorite and its aplite margin. This behaviour indicates that the sheets were intruded after the emplacement of these granites, but before the final stages of solidification came to an end.

The origin of the net-veins will be briefly discussed in section XII. 


\section{SYNKINEMATIC DYKES}

On Julianehåb peninsula, along Torssukátak fjord and on Qarmat land there are concentrations of dykes or sheets varying in composition from basic to granodioritic. Their setting and characteristic features are different from dykes intruded under tensional conditions into cold crust. As the dykes of the south-eastern part of Julianehåb peninsula escaped the influence of subsequent granite development in the crust, these will be described first in some detail.

\section{Form of the dykes}

The dykes have parallel walls that are steeply dipping or vertical. The width of individual dykes varies between a few centimetres and

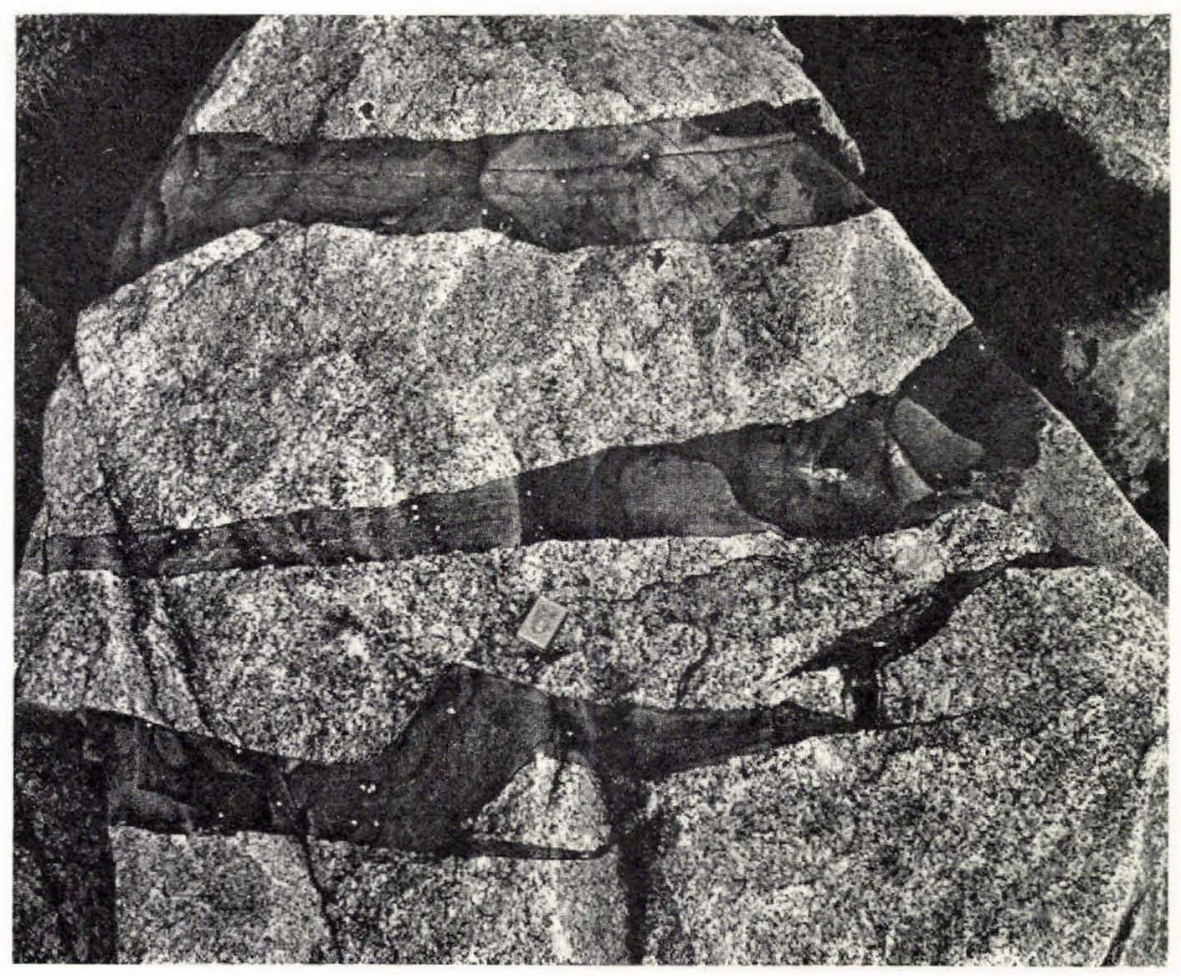

Fig. 2. Thin synkinematic dykes with apophyses and en bayonet structures. Southeastern side of Julianehåb peninsula. 

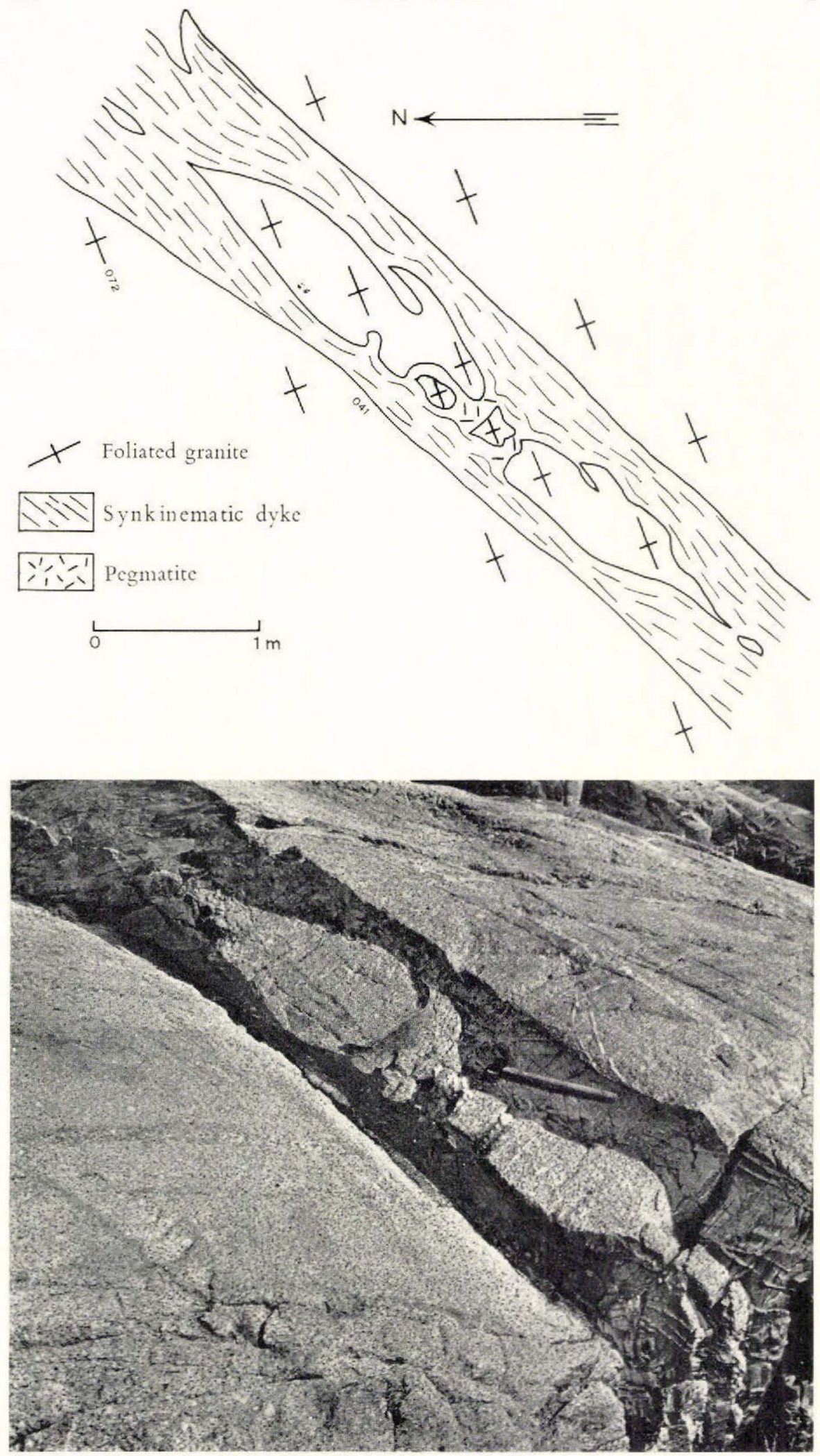

Fig. 3. Synkinematic dyke with septum of country rock granite which is boudinée. There are infillings of pegmatite between the boudins into which the foliation of the dyke is deflected (see drawing). South-eastern side of Julianehåb peninsula. 
about $20 \mathrm{~m}$, but is most commonly between 0.2 and $2 \mathrm{~m}$. Single dykes and groups of two or three thin dykes have been observed as well as swarms of a few tens of dykes with an average width of a few metres. Some of these can be followed for several kilometres. Many dykes are straight over long distances, while others have an irregular course. Features such as bayonet structure with or without apophyses, en echelon arrangement, etc. (fig. 2) have been observed in many places. In some cases the apophyses show peculiar relations to hot shear zones (see ahead). Inclusions of country rock occur frequently as well as septa which may be several metres long (fig. 3). Some dykes transect basic inclusions or basic schlieren in the granite, leucocratic veins and hot shear zones.

Some of the above features are similar to those of tensional dykes intruded into cold crust and they clearly demonstrate that the country rock could fracture during the intrusion of the dykes to be described in the present section.

\section{Mutual relations and internal structures}

Three main varieties can be distinguished.

a) Green dykes of basic and often biotite-bearing rock. These have usually a much less regular course than the second variety.

b) Grey dykes of basic to intermediate composition.

c) Granodioritic dykes which are light grey in colour. Thicker dykes of this variety consist of foliated granodiorite porphyry.

Ten intersections, mainly exposed to the north of Iterdlak bay, between dykes of different generations enable the establishment of the following succession:

\section{E-W to ENE green \\ 3. NNW to $\mathrm{N}$ (NNE?) grey \\ 2. NW to NNW green \\ 1. NNE to NE grey}

Along the southern side of the peninsula granodioritic dykes are common. There are at least two generations, the older trending $\mathrm{NE}$ and the younger $\mathrm{N}-\mathrm{S}$. The age relations with the other varieties are not known with certainty, but the thickest NE-trending dyke contains numerous inclusions of the green and grey dykes. The granodioritic dykes are thus comparatively younger.

As a rule the dykes are heterogeneous. Feldspar megacrysts are not uncommon in the grey dykes. Small mostly spindle-shaped aggregates of hornblende are ubiquitous and especially common in the central parts of the green dykes. In the centres of some dykes veins occur slightly richer 


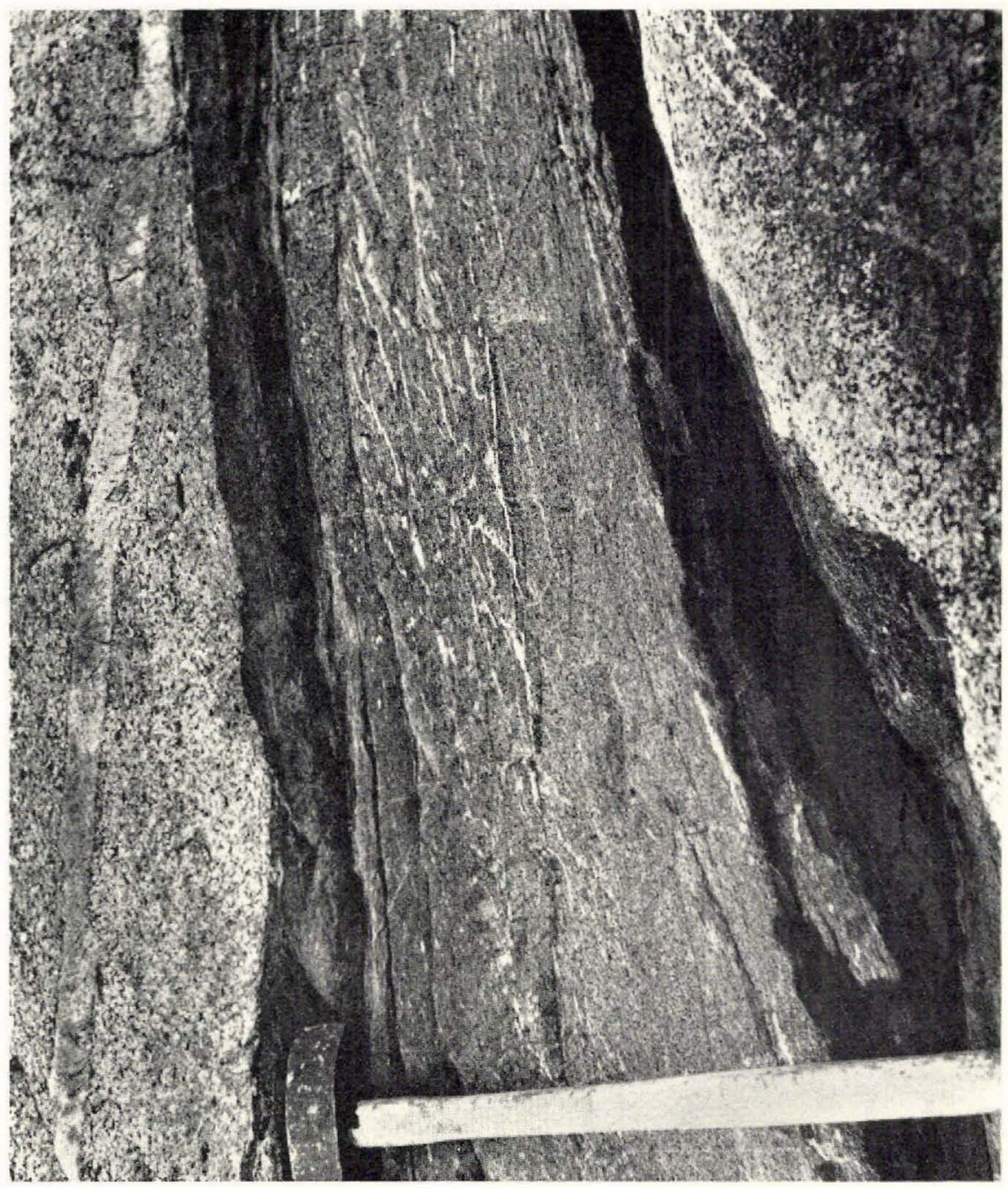

Fig. 4. Synkinematic dyke with differentiation veins. South-eastern side of Julianehåb peninsula.

in plagioclase than the dyke rock itself. These form a network of veins slightly oblique to the internal foliation, dividing the more basic dyke rock into elongated lenses which lie parallel to the internal foliation, as is shown in fig. 4. Occasionally the distribution of these veins is more irregular.

The dyke rocks have a foliation and/or lineation marked by the orientation of the hornblende aggregates and by the distribution and orientation of the dark minerals in the ground mass. When seen on horizontal surfaces the foliation (lineation) has generally a sigmoidal 


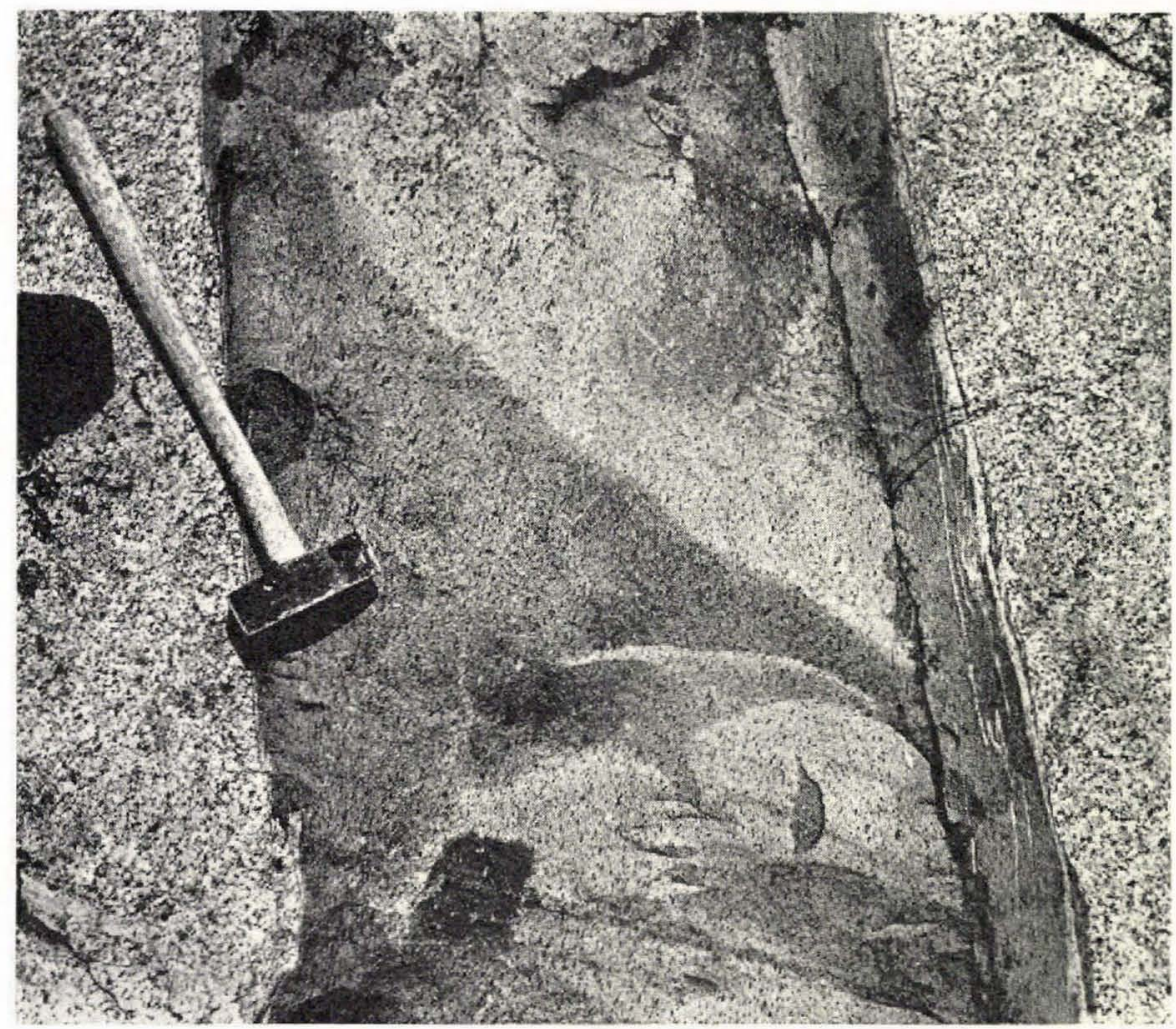

Fig. 5. Synkinematic dyke with sigmoidal pattern of lineation which is marked by the orientation of spindle-shaped hornblende aggregates. The lineation is horizontal and practically parallel to the plane of exposure. Southern side of Julianehåb peninsula.

course (fig. 5). Some of the dykes displace older structures in the host rock. Dykes with dextral displacement have an S-shaped sigmoidal foliation and those with sinistral diplacement a $\mathrm{Z}$-shaped foliation. It is clear therefore that the sigmoidal pattern is partly due to movement along the dyke fissures. As a rule the linations in the dykes are close to the horizontal and this suggests that generally there was no or only a small vertical component of displacement. The foliation is usually more clearly displayed in the green than in the grey dykes. In some of the former the foliation is microfolded.

As can be seen in fig. 6 (see also fig. 12) the internal foliation follows closely all irregularities in the course of the dykes. This shows that the attitudes of the dyke walls played an important part in determining the trends of the internal foliation. As it is difficult to conceive how such relationships can originate by deformation of solidified dykes it is concluded that the foliation was at least partly attained shortly after the 


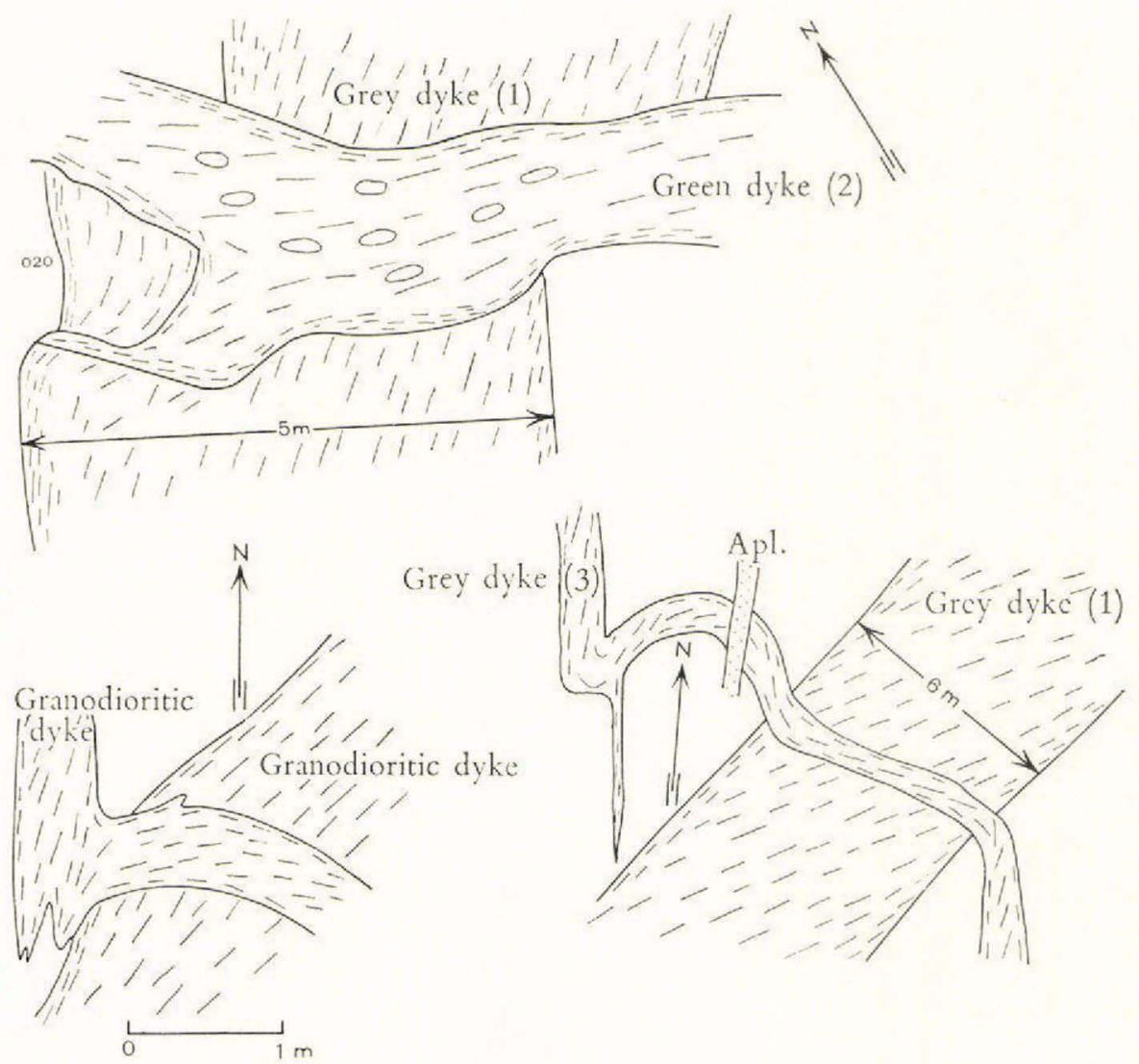

Fig. 6. Intersections between successive generations of synkinematic dykes. The foliation of each older dyke is truncated by a younger dyke. The numbers between the brackets indicate the place of the dykes in the succession given on p. 27. North of Iterdlak bay, Julianehåb peninsula.

intrusion of the dykes. This conclusion is in accordance with the fact that in all intersections the internal foliation of the older dykes is truncated by that of the younger, as is shown in fig. 6 . It should be noted that the internal foliation in tensional dykes, which after their consolidation were deformed and folded under plutonic conditions, is largely independent of the attitudes of the dyke walls, but parallel to the new foliation in the country rock (see pp. 57, 89, 90, 104 and figs. 19, 39,40 and 41).

The septa of country rock in the dykes are straight and long. In a few cases boundinage-like features have been observed. In fig. 3 an example is shown in which pegmatite fillings have developed between the boudins. 


\section{Petrography}

The green dykes have a basic composition, hornblende usually amounting to $35-45 \%$, biotite $10-20 \%$ and plagioclase $35-45 \%$ by volume. The grey dykes are basic to intermediate in composition and usually the plagioclase clearly predominates over the mafics.

In the grey as well as in the green dykes the hornblende is either a bluish green variety or an actinolitic variety. Plagioclase $\left(\mathrm{An}_{20-30}\right)$ is usually slightly zoned and in some of the green dykes more basic relicts $\left(\mathrm{An}_{50}\right)$ were encountered. Small quantities of microcline and quartz are common. The rocks are fine- to medium-grained; even in thicker dykes the average grain size is close to $1 \mathrm{~mm}$. Aggregates of hornblende with or without biotite are regularly distributed and frequently these are densely packed in a granoblastic matrix mainly consisting of plagioclase. The texture of the rocks is crystalloblastic. On a small scale a mineral separation is common in the green dykes, but it is less pronounced in the grey. This is marked by an alternation of thin discontinuous bands and lenses of the light and dark minerals.

Another type of mineral separation, on a larger scale than that just described, has already been mentioned and illustrated in fig. 4. It is marked by the presence of irregular veins, up to a few centimetres wide, mainly consisting of plagioclase. These veins are either regularly distributed, or more commonly, concentrated in the centres of the dykes where they form a network dividing the basic rock into elongated lenses parallel to the internal foliation. As a rule they are oblique to the foliation in the dykes. The amount of biotite in the veins is not lower than in the surrounding dyke rock. Hornblende is present in small quantities and forms either regularly distributed small crystals or occasional aggregates. The composition of the plagioclase from the veins is not different to that outside the veins, so that an origin by alkali metasomatism can be excluded. The oblique attitude relative to the crosscutting internal foliation suggests that they originated before the deformation that produced the internal foliation had ceased. These relations are in accordance with Watterson's (1965, p. 98) explanation of similar phenomena in synkinematic dykes in the Ilordleq area. These phenomena were considered to have originated as a result of "differentiation by deformation during crystallisation within the dyke fissures". It should be noted that no perceivable enrichments of mafics have been observed adjacent to the veins in the internally deformed dykes of Julianehåb peninsula.

Recognisable relicts of the earliest stages of crystallisation are rare, as these were almost completely destroyed by the intense deformation in the dykes. Only in a few thin dykes are there euhedral megacrysts which are interpreted as phenocrysts. In some dykes, a few metres wide, 
there are numerous subhedral crystals of plagioclase a few millimetres in size which are clearly more basic than the plagioclase of the matrix. Successive stages in the recrystallisation can be distinguished from these single crystals to fine-grained aggregates of small equidimensional crystals with a similar grain size to that of the ground mass. The anorthite content shows a similar series of changes from the initial basic to intermediate composition of the larger single crystals to the oligoclase composition of the plagioclase of the fine-grained aggregates which is the same as that in the matrix. Here and there the subhedral crystals and the aggregates of the wider dykes are so regularly distributed that it appears as if the rock previously consisted of an aggregate in which the plagioclase had a grain size at least three times as large as at present. It is noteworthy that the subhedral plagioclase crystals have a very short tabular habit and that they have a random orientation.

There are very few recognisable relicts of the primary maficigneous components. In a few thin sections of green dykes cut parallel to the lineation there are acicular hornblende megacrysts with their $c$-axis parallel to the foliation. Some of these are bent and broken into fragments with the same interference colour. As there are no indications that pyroxenes ever existed in the dykes, these oriented, acicular hornblende megacrysts can safely be interpreted as early crystallisation products formed under directed stress. Their rare occurrence permits however only the conclusion that at least in some of the dykes crystallisation and deformation were contemporaneous.

In the green dykes biotite is occasionally present in considerable quantities. Aggregates with thin rims of small hornblende crystals are not uncommon. Possibly these represent early biotite megacrysts. Most of the biotite is late and replacing the hornblende. Orthite, epidote, apatite, titanite and ore are accessories.

The margins of the dykes are always very fine-grained and completely recrystallised.

The granodioritic dykes have a high quartz-microcline content. In places they contain less microcline along their margins than in the centres. The dyke rock is usually porphyritic, plagioclase phenocrysts strongly predominating over those of microcline. The former, occupying $20-30 \%$ of the rock volume, are strongly zoned with basic cores up to $\mathrm{An}_{50}$. The foliation planes usually bend around the phenocrysts and occasionally there are resultant pressure shadows in which quartz and microcline are concentrated. In the centres of some thin dykes ovalshaped hornblende aggregates occur surrounded by thin, leucocratic rims consisting of microcline. Evidently a metamorphic differentiation has been responsible for the formation of these rims.

In the wider dykes a foliation is clearly displayed and marked by the orientation of thin platy aggregates of hornblende with or without 
biotite. The phenocrysts are embedded in a fine-grained granoblastic matrix of plagioclase and microcline with a little hornblende and biotite. In the widest dyke of this group which is very rich in basic inclusions, it can be seen that at least scme of the hornblende aggregates have been derived by digestion of the inclusions.

It can be concluded that in at least some of the dykes crystallisation and deformation were practically contemporaneous. It seems however, that deformation continued after the solidification of the rocks and destroyed the greater part of the primary textures.

The present mineral assemblage of the dykes, bluish green hornblende, actinolitic hornblende, oligoclase, biotite and epidote, suggests that the last stage of deformation in the dykes took place under conditions close to the boundary between the greenschist and amphibolite facies (Abukuma type?; WinkLER, 1965).

A further genetically significant point is that in no dykes have relicts of primary pyroxene been found. The long prismatic habit of the preserved hornblende megacrysts suggests that they are true phenocrysts and not pseudomorphs after an earlier mineral. The fact that a few phenocrysts have survived the influence of recrystallisation and deformation makes it highly improbable that primary pyroxene has existed in the synkinematic dykes and been destroyed. Similar observations concerning consistent absence of primary pyroxene have been made from synkinematic dykes in Ilordleq (Watrerson, 1965), the Sârdloq area (WindeEY, 1966 a) and farther to the east in the Akuliaruseq area (Persoz, in press).

\section{Relations to hot shear zones and leucocratic veins}

In the country rock granite "hot shear zones" are rather common. There are several sets, trending NE, NNE to N, N to NNW and NW. Narrow zones are a few millimetres wide and occur either singly or in swarms (see fig. 8); the width of the broader zones usually does not exceed a few metres.

Different age relations have been established between the hot shear zones and the dykes. Some dykes transect or even displace hot shear zones, while other dykes are displaced by hot shear zones. In many cases however the dykes send apophyses into the zones, a typical example of which is illustrated in fig. 7. The observations along this dyke showed that the shear zone into which the apophysis penetrated does not continue on the other side of the dyke. It seems therefore that the shear zone is not earlier than the dyke. In the zone a fracture cleavage is displayed oblique to its course (Z-shape) with the same sense of movement as that indicated by the sigmoidal foliation in the apophysis and the dyke itself. 


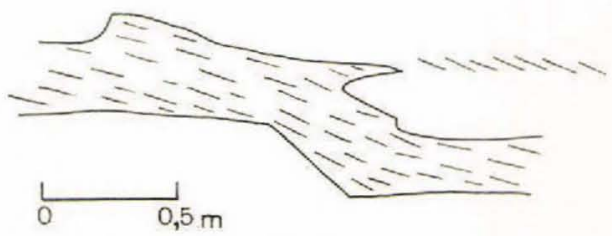

Fig. 7 a.

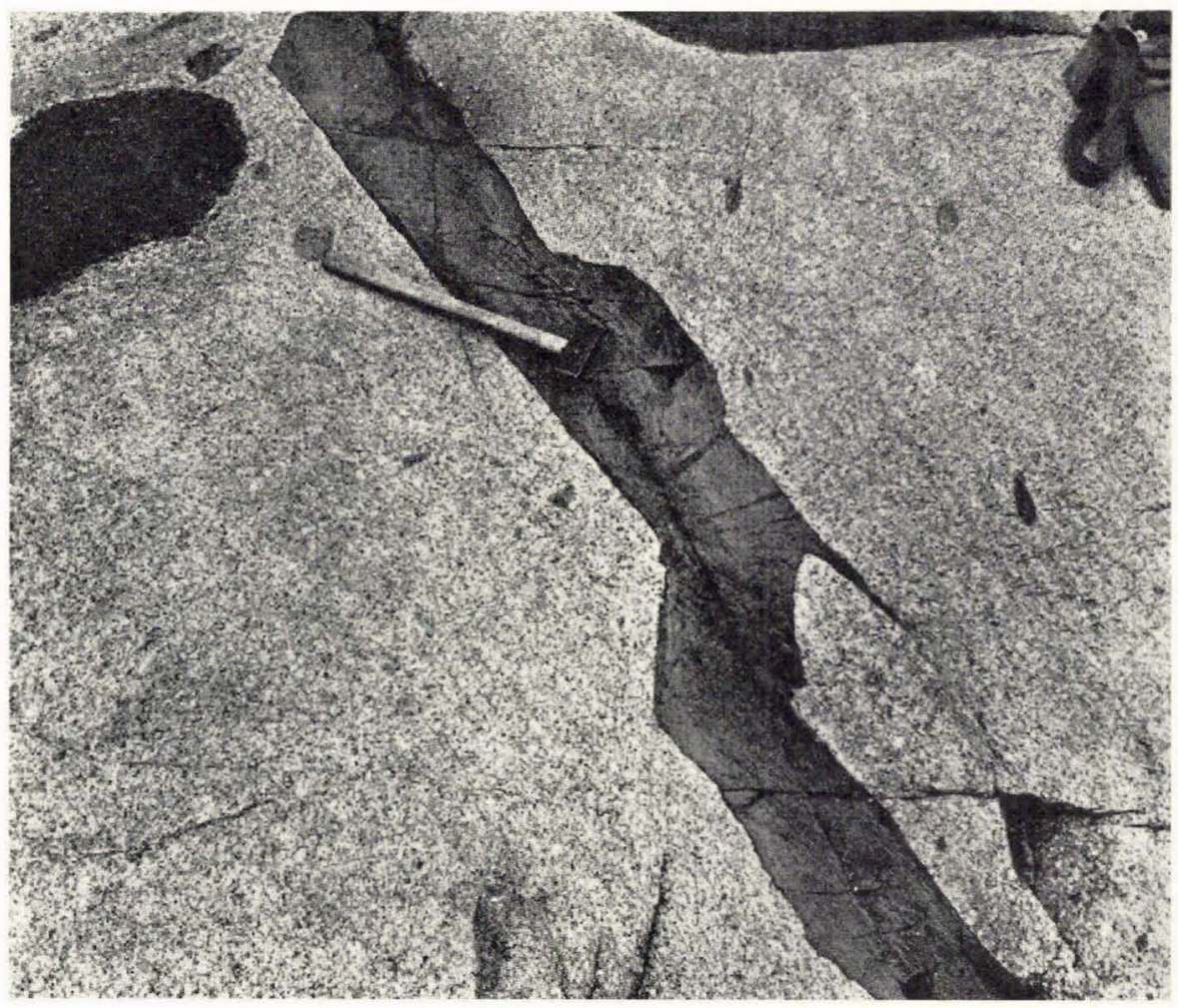

Fig. $7 \mathrm{~b}$.

Fig. 7. Synkinematic dyke an apophysis of which has penetrated a contemporaneous hot shear zone. The foliation in the shear zone is oblique to its trend and parallel to the sigmoidal foliation in the apophysis. Eastern side of Julianehåb peninsula.

These relations suggest that deformation operated simultaneously in both dyke and shear zone. It may thus be concluded that shearing and dyke intrusion were contemporaneous.

In a few localities immediately to the south-west of Julianehåb it has been possible to establish local sequences of events, viz. leucocratic veining, formation of hot shear zones and intrusion of the internally deformed dykes. These chronologies will now be dealt with as they illustrate some characteristic traits of the setting of these dykes. 


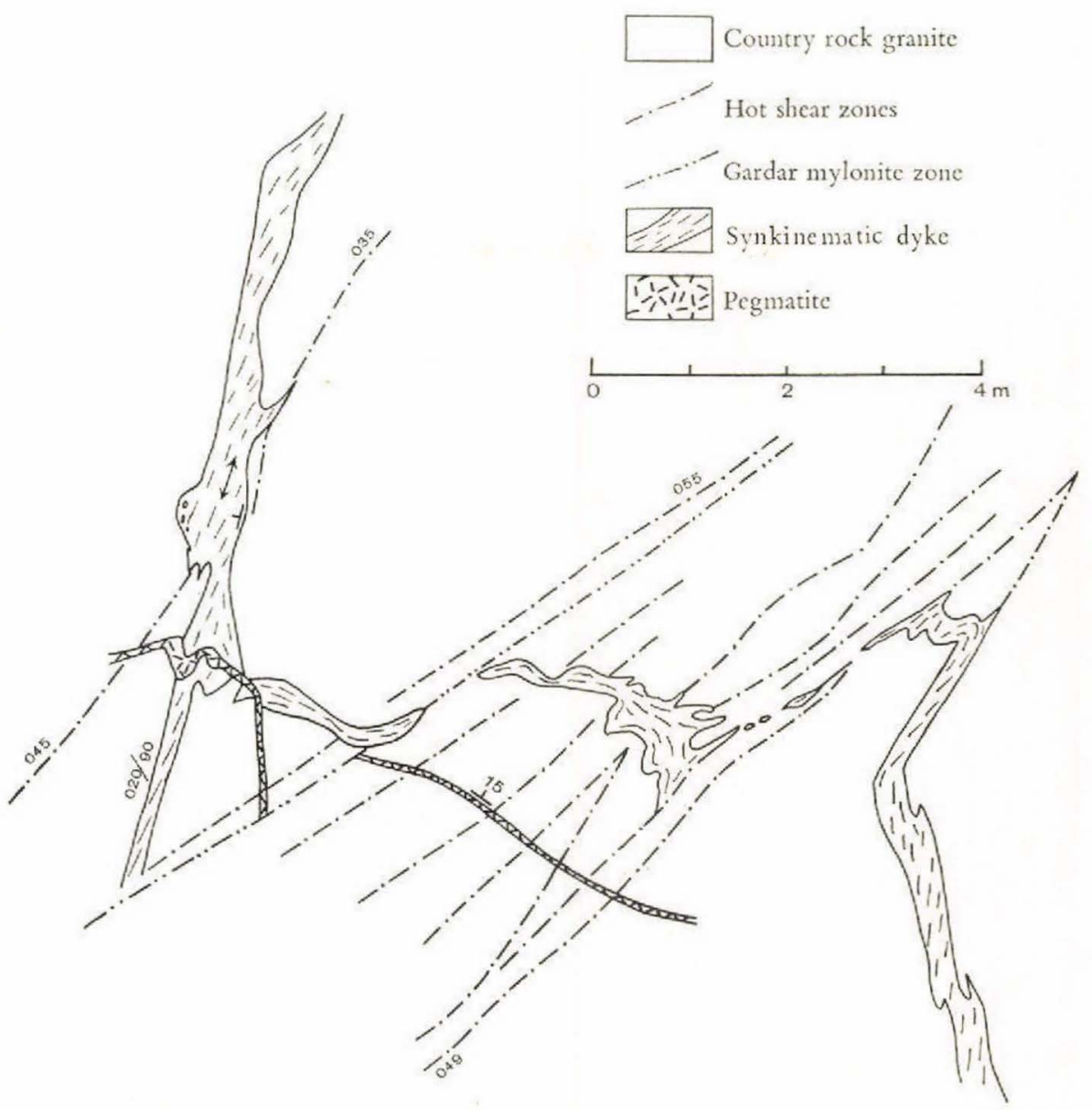

Fig. 8. Relations of a synkinematic dyke to a swarm of hot shear zones in which repeated movement has taken place. South-west of Julianehåb (locality 1).

In fig. 8 (locality 1) the relations are shown between a NE-trending belt of hot shear zones, in which repeated movement has taken place, and an internally deformed dyke. After the first phase of shearing aplite veins with an $\mathrm{E}-\mathrm{W}$ trend were emplaced (these are not visible in the fig.) and later the dyke was intruded, as is shown by the crosscutting relations to the oldest shear zones, and deformed internally. Subsequently along the south-eastern side of the belt hot shearing was repeated with sinistral displacement of the dyke. This was followed by emplacement of two generations of aplite veins and partial pegmatisation of the youngest aplites. Finally the dyke was displaced by a thin mylonite zone along the north-western side of the belt; this mylonite contains chlorite and epidote. Evidently this thin zone was formed at lower temperatures than the hot shear zones. 


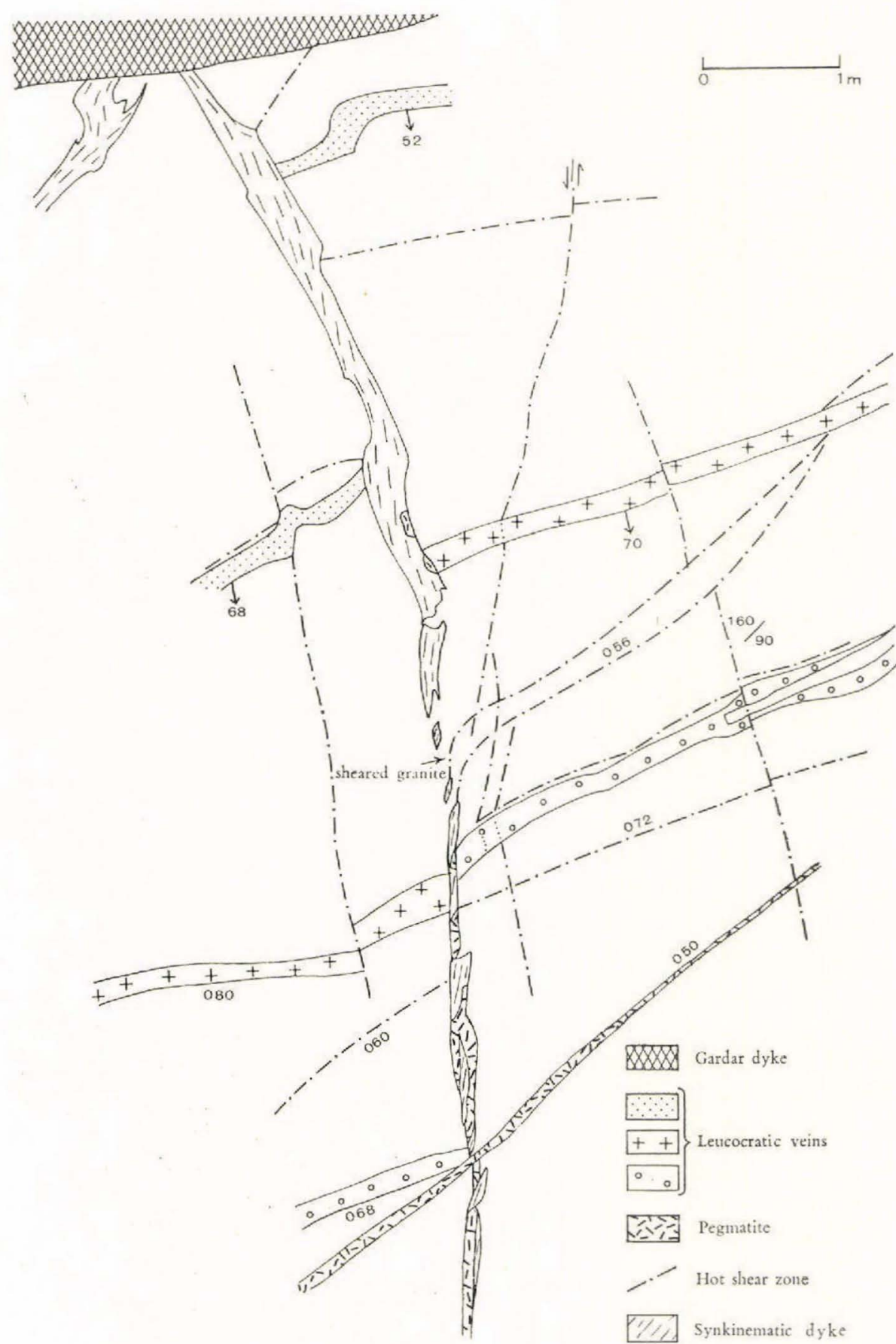

Fig. 9. Synkinematic dyke with sigmoidal pattern of foliation, crosscutting and displacing hot shear zones and leucocratic veins. South-west of Julianehåb (locality 2). 
Table 2. Local succession of events south-west of Julianehåb.

\author{
Aplite veins \\ Veins of foliated granite \\ Internal deformation of the dyke \\ Synkinematic dyke ( $N-S$ to $N-N W$, locality 2) \\ Aplite granite (107/90-70/70SE) \\ Hot shear zones $(160 / 90$ to $\mathrm{N}-\mathrm{S})$ \\ Reactivation of $045-065$ shear zones \\ Internal deformation of the dyke \\ Synkinematic dyke ( $N-S$ to $N N E$, locality 1) \\ Aplite veins (E-W; dipping steeply south) \\ Hot shear zones $(010 / 90$, locality 2) \\ (oldest) \\ Hot shear zones (045-065/90)
}

Fig. 9 (locality 2) shows an example of a dyke with Z-shaped internal foliation which displaces sinistrally a number of shear zones and leucocratic veins. At this locality it has been possible to establish a succession of two phases of hot shearing (both with an ENE trend and not visible in the fig.) separated by a generation of aplite veins with the same trend as the first generation aplites described in the first locality. After the second phase of ENE shearing another aplite generation was emplaced followed by the intrusion of the basic dyke. The distance between locality 1 and 2 is about $600 \mathrm{~m}$ and it is reasonable to correlate the two phases of ENE shearing and the intervening aplite generations established in each locality, so that the succession given in table 2 can be established. The internally deformed dykes at these localities evidently belong to different generations and it is clear that in each case their emplacement alternated with mylonitisation and leucocratic veining. These relations are considered as a conclusive criterion for the distinction of the dykes under consideration from dykes emplaced under tensional conditions into a cold crust.

In many places leucocratic veins cut through the internally deformed dykes and on entering these they change their direction and become folded. The thinner veins are always shear folded within the dykes, the foliation of the dyke being parallel to the axial plane of the folds. In comparison, the folding of the thicker veins is much less regular and the foliation in the dykes is bent and follows the irregularities of the folds. Evidently the thicker veins were relatively more competent with respect to the dyke rocks than were the thinner veins. In places several generations of leucocratic veins are folded within the dykes.

On entering a deformed dyke, some leucocratic veins follow its course for some distance and then pass into the country rocks on the 


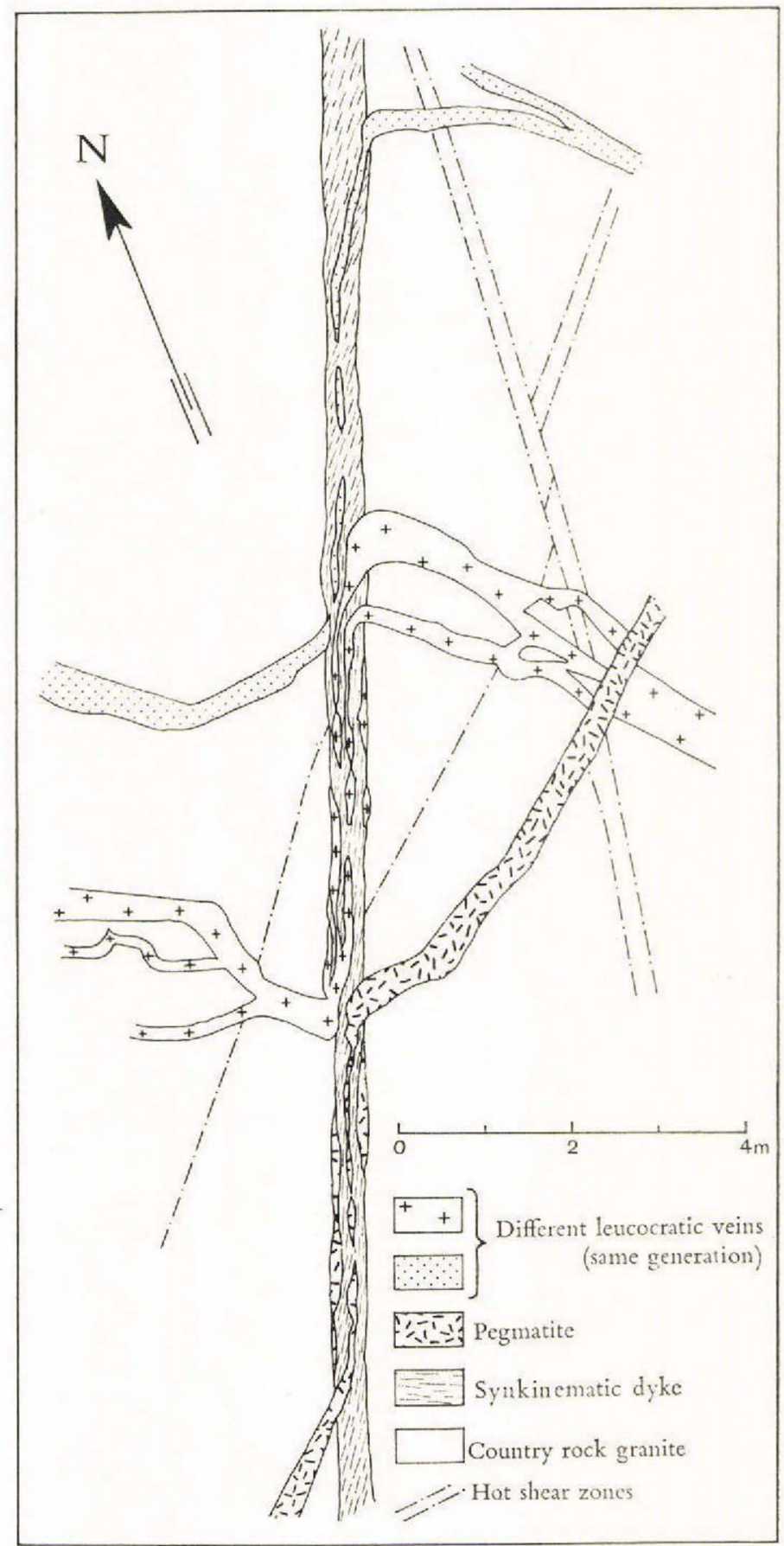

Fig. 10. Synkinematic dyke along which later leucocratic veins have been displaced. The leucocratic veins are partly earlier than and partly contemporaneous with the subsequent internal deformation in the dyke. South-eastern side of Julianehåb peninsula. 
other side of the dyke. A typical example of this is given in fig. 10. Two aplitic veins belonging to the same generation and a later pegmatite follow the dyke for several metres. In the dyke the veins are locally boudinée and one vein is locally folded. In the country rock the pegmatite and the aplites have different directions, but nevertheless when entering the dyke they all turn to the left. It is therefore clear that the veins are younger than the dyke and that the internal deformation continued during and after the emplacement of the veins. The amount of displacement of the older aplites is about $7 \mathrm{~m}$ and that of the younger pegmatite about $5 \mathrm{~m}$. This might indicate that deformation also took place between the emplacement of the aplites and the pegmatite. These phenomena suggest that the deformation in the dykes had lasted some time. Petrographical evidence also suggests that deformation has continued after the dyke rock had become solid. It has to be emphasised that features similar to those in the two last paragraphs have also been found in metadoleritic dykes which consolidated in the absence of stress and were subsequently deformed and recrystallised in connection with plutonic activity (see e.g. WAtTERson, 1965, fig. 39).

Some leucocratic veins however transect the dykes without any change in course. These veins crosscut, and are thus later than, those which are folded within the dykes and they represent a later stage of declining plutonism during which the difference in behaviour between dykes and country rock was no longer critical.

\section{Relations of the synkinematic dykes to a regional stress field}

All of the granodioritic, intermediate and basic dykes described in the preceding pages show typical intrusive features. Throughout the Julianehåb peninsula there are no signs of the country rock granite attacking or back-veining the dykes. These relationships demonstrate the brittle conditions prevailing in the crust at the present level of exposure throughout the episode of intrusion of the successive dyke generations.

Petrographic evidence shows that the internal deformation in the dykes took place at elevated temperatures (boundary greenschistamphibolite facies) and there are indications that at least in some dykes directed stress operated during the early stages of crystallisation. This is supported by the peculiar relations of the dykes to hot shear zones which were formed contemporaneously with the dyke intrusion, so that the conclusion is warranted that the dykes were intruded into active movement zones. As has been previously shown the sigmoidal foliation generally reflects the sense of movement which has taken place along the dyke fissures. The sense of sigmoidal foliation in the synkinematic dykes of different trends is not arbitrary and this confirms a suggestion already 

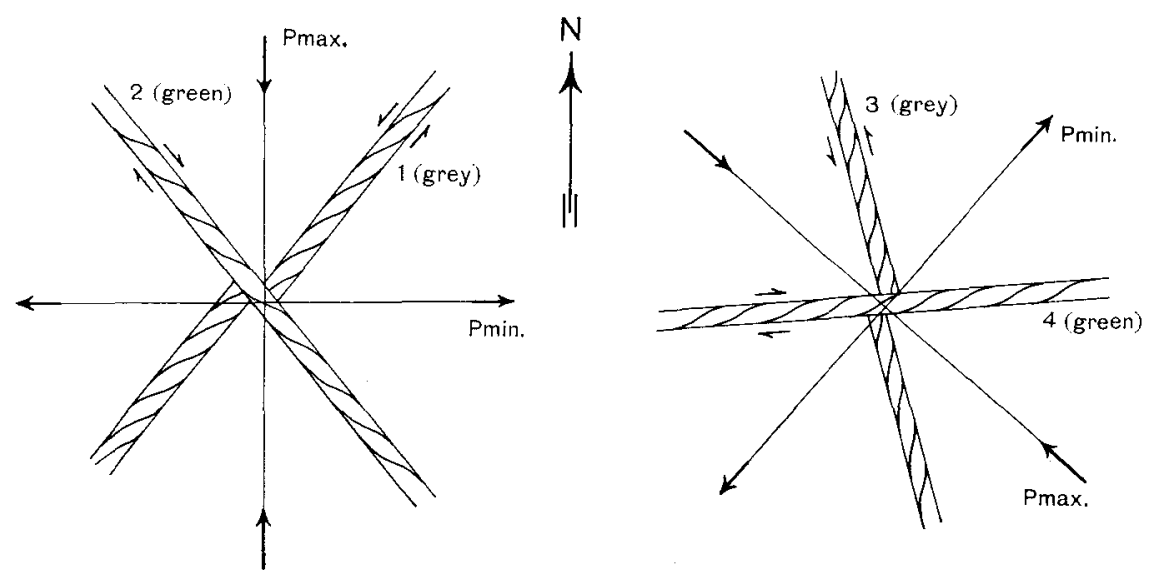

Fig. 11. Schematic representation of the four generations of grey and green synkinematic dykes in relation to the stress fields which possibly operated during their intrusion (see succession on p. 27).

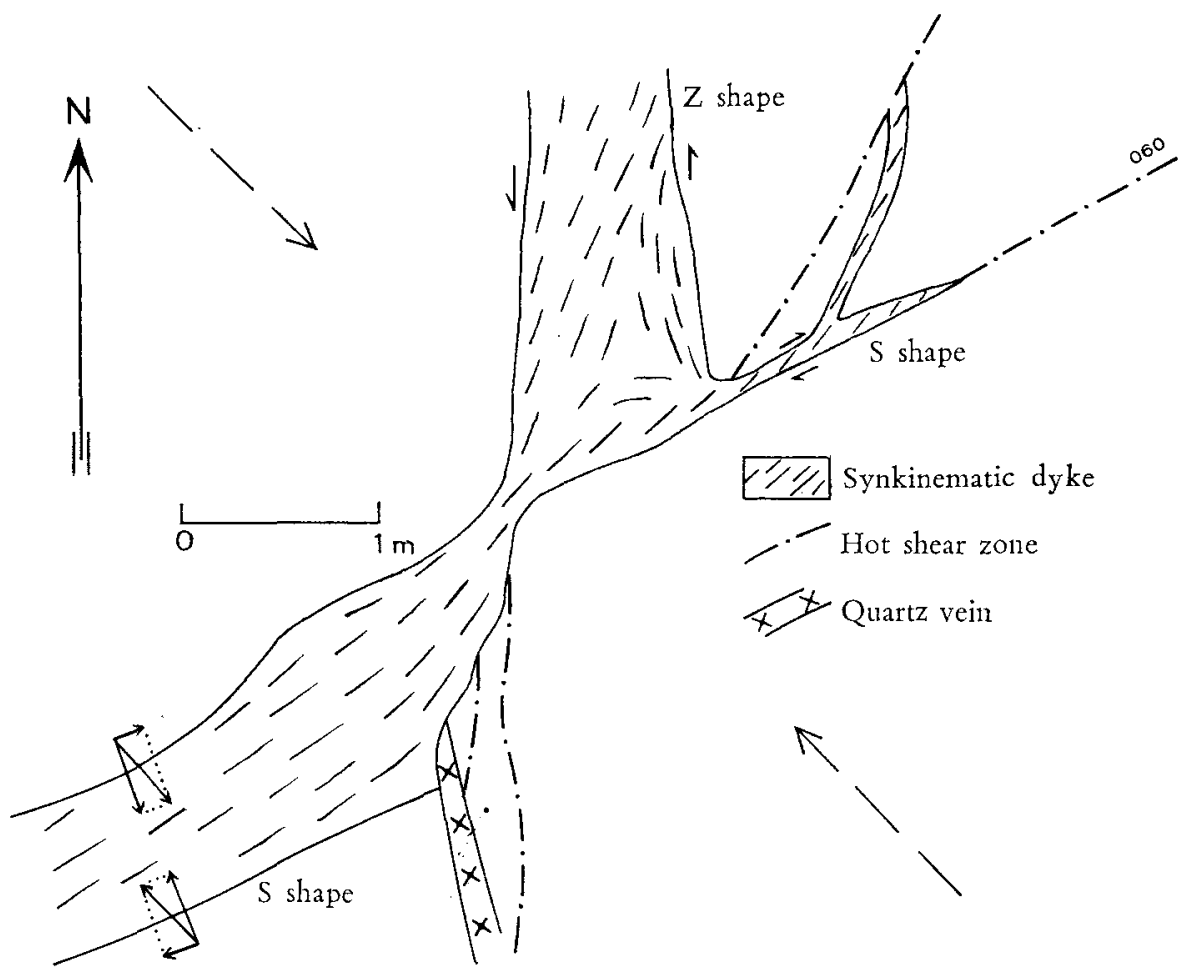

Fig. 12. Synkinematic dyke with different senses of sigmoidal foliation. Southern side of Julianehåb peninsula. 
put forward by Watterson (1965, p. 99) that synkinematic dykes from the Ilordleq area were successively emplaced along conjugate shear fractures formed by a regional stress field parallel to that operating during the 2nd episode of Ketilidian plutonism. The orientation of the first and second generation of the synkinematic dykes of Julianehåb peninsula and their respective senses of movement is consistent with their successive intrusion during operation of a stress field with its main axis of compression in a $\mathrm{N}-\mathrm{S}$ direction (see fig. 11). However the main axis of the stress field which can be deduced to operate during the intrusion of the third and fourth generations of synkinematic dykes has a NW-SE direction. It seems that even in individual synkinematic dykes and apophyses with widely varying trends the senses of sigmoidal foliation in their different parts and apophyses are determined by the position of the stress field operating during their intrusion. A typical example of a granodioritic dyke younger than the two earliest generations of synkinematic dykes is shown in fig. 12. The senses of sigmoidal foliation in its different parts are consistent with a NW-SE compression.

The change of the deduced main pressure direction from $\mathrm{N}-\mathrm{S}$ to NW-SE after the intrusion of the two earliest generations of synkinematic dykes is of interest. The following explanation is suggested. The south-eastern part of Julianehåb peninsula, where the synkinematic dykes are mainly concentrated, constitutes the core of a body of allochthonous granite (variety 4). As will be suggested later on, the dykes are closely related to the later stages of consolidation in the granite body. It is plausible that during the intrusion of the two earliest generations of synkinematic dykes the stress field was influenced by local conditions within the body, while during the intrusion of the later generations the stress field had returned to the position of the regional stress field in the mobile belt.

\section{Other occurrences of possible synkinematic dykes}

In the core of the allochthonous Qarmat granite body numerous strongly disrupted dyke relicts occur. Some of these show properties which are strongly reminiscent of those of the synkinematic dykes from Julianehåb peninsula. There are at least two generations of these dykes, a green basic type and a bluish grey dioritic type. The dykes were migmatised and strongly recrystallised after their emplacement. However, a sigmoidal foliation is still recognisable in a few localities and occasionally the grey dykes wedge out into fine-grained and biotite-rich zones which probably represent recrystallised hot shear zones. One green dyke, although disrupted, could be followed for $300 \mathrm{~m}$. Observations in the Qarmat body suggest that these dykes postdate a phase of stretching in 
the granite evidenced by the extreme discontinuity of remnants of earlier amphibolite dykes.

Along Torssukatak fjord there is a great number of migmatised and disrupted dioritic sheets belonging to three successive generations. They are flat-lying and occur at regular intervals; here and there they are connected by vertical dykes. In most of the sheets an internal foliation and a lineation, consistently plunging ENE, are well displayed. Folded aplitic veins are widespread and the internal foliation follows the axial planes of the folds. Some of the sheets are undeformed and in these original igneous textures, such as a tabular habit of the plagioclases, can be recognised. No relicts of pyroxene have been found in thin sections, even of the undeformed sheets. The sheets postdate a body of allochthonous granite (variety 4) and the thick mantle of aplitic granite which surrounds the north-western side of that body. The internal foliation and the absence of pyroxene in the sheets might indicate that their origin is similar to that of the synkinematic dykes of Julianehåb peninsula.

In the gneisses along the inner part of Torssukatak fjord five slightly discordant basic dykes occur which have an appearance identical to that of the synkinematic dykes described in the preceding pages. The dykes have a sigmoidal foliation; the rocks contain numerous spindle-shaped aggregates defining a lineation. The so-called differentiation veins which are so typical of the synkinematic dykes from Julianehåb peninsula are extremely well developed. These are usually parallel with and close to the margins. In one place such a vein proceeds diagonally through one of the dykes. Their field relations suggest however that they are much older than the other dykes described in this section (see p. 97). 


\section{PYROXENE-BEARING DIORITES}

\section{Occurrence and field relations}

In an area of homogeneous granite between Takissoq and Pârdlitt dioritic intrusive bodies are very common. Along Bredef jord a NWtrending swarm of thin dykes has been recorded and north of the inner part of Torssukátak f jord there are a few other bodies.

In the Takissoq-Pârdlît area there are three small laccolithic bodies varying in diameter between $100 \mathrm{~m}$ and $1 \mathrm{~km}$. From these a great many low-dipping sheets invade the country rock granite at regular intervals. In places there are vertical connections between the sheets. On the island Sivingarngup nunâ three to four relatively thick, ENE-trending vertical dykes occur. One of these is slightly more basic than the others and can be followed farther towards Pârdlit (see fig. 13). The course of the other dykes is slightly irregular; they converge in some places and bifurcate in others and elsewhere they are connected by low-dipping sheets. In contrast with the metadolerites from Pârdlitt and Julianehåb peninsula, to be described in section VIII, the sheets and dykes of pyroxene-bearing diorite are always continuous and can be followed for very long distances.

Along the margins of the three laccolithic bodies the diorite is fine-grained as are most of the thinner sheets which extend from them. The widespread preservation of original igneous textures in both the bodies and the sheets shows that the decrease in grain size is a result of chilling, suggesting that the diorites were emplaced into country rock which was appreciably colder than the intruding material.

In the field the impression was obtained that the sheet rocks often are richer in plagioclase than the diorite of the laccolithic bodies. Moreover the smallest of these bodies is more basic than the other two. This has been confirmed by microscopic observations and chemical analyses (section IX).

The pyroxene-bearing diorites were generally extensively migmatised after their intrusion. Different types of migmatisation and pegmatisation developed during successive phases of granite development. These will be described in section XII. 


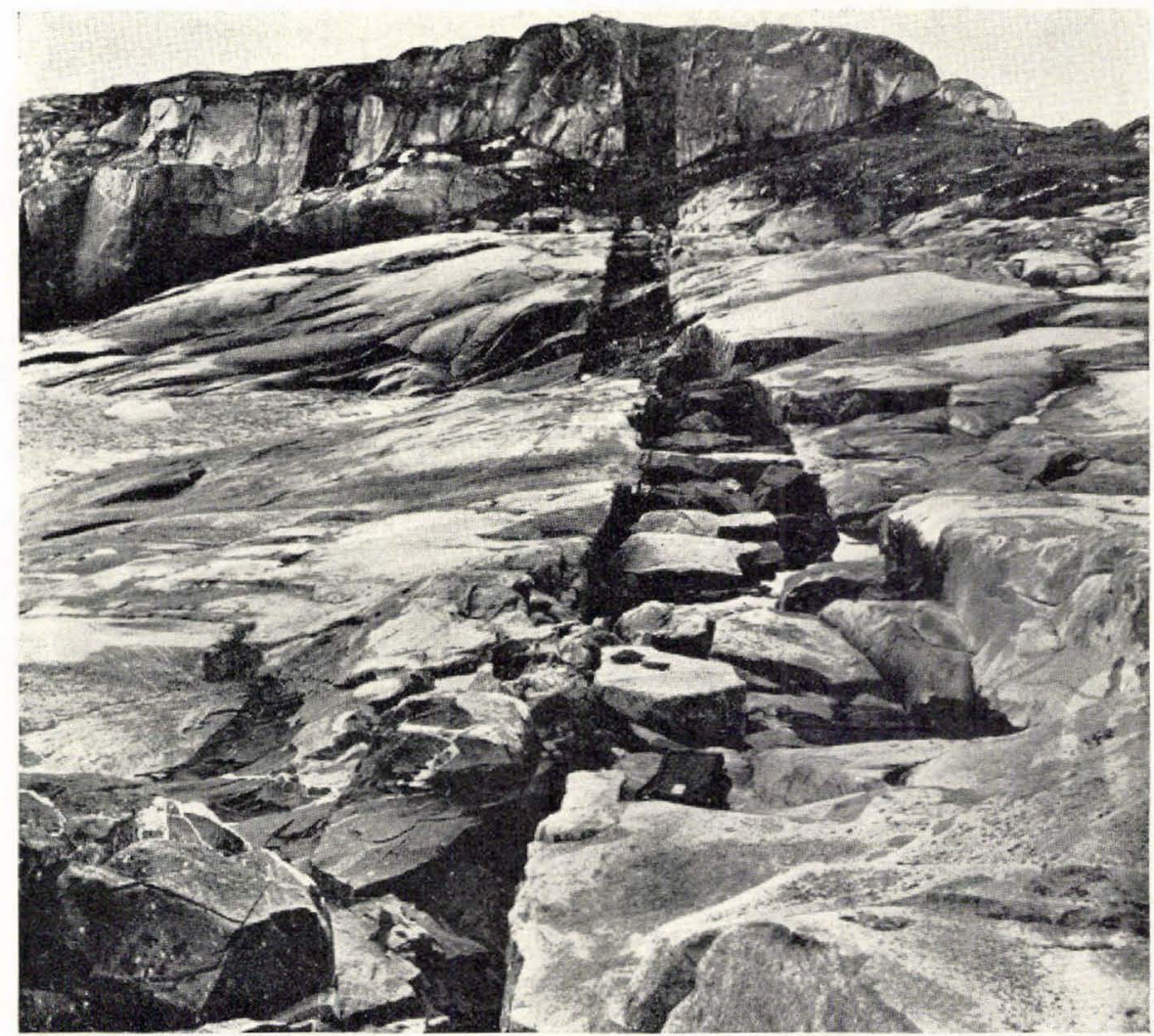

Fig. 13. Dyke of pyroxene-bearing diorite in Julianehåb granite (variety 4). The dyke is displaced by a crosscutting sheet-like body of leucocratic biotite granite. Pàrdlit island.

\section{Internal structures and microscopic observations}

Firstly occurrences will be described from the area between Takissoq and Pârdlit, then follow a few important features of a dyke with doleritic affinities from Pârdlit and lastly brief descriptions will be given from localities where recrystallisation had a stronger effect than usual.

The rocks of the three laccolithic intrusive bodies vary from mediumto almost coarse-grained and are of intermediate composition, although the smallest seems to be relatively basic. The percentage of the modal plagioclase is usually fifty or more, hornblende amounts to $20-30 \%$ and biotite $10-20 \%$. The tabular habit of plagioclase is usually well marked, as can be seen in hand specimens. The crystals have cores of basic andesine and broad rims of oligoclase. Large hornblende crystals occur here and there in ophitic relation to the feldspar laths. Usually the hornblendes have light coloured cores, in which relicts of clinopyroxene 
commonly occur, and green rims which are seen to encroach upon the feldspars. Part of the light coloured hornblende is replaced by a green hornblende which is strongly polysynthetically twinned. The biotite forms either large plates or small flakes which are of secondary origin and related to shearing. Ore, titanite, apatite and quartz are accessories.

Sheets which extend from the three bodies are more fine-grained and rich in small tabular plagioclase crystals (oligoclase-andesine) with distinct normal zoning. Hornblende forms subhedral crystals most of which contain relicts of clinopyroxene. Biotite forms irregular plates. The sheets extending from the smallest body are less basic than the parent body. In some of the sheets and dykes the rock is porphyritic, hornblende megacrysts and aggregates and plagioclase phenocrysts being present in considerable quantities. The feldspars usually form clusters of radiating crystals. In the wider dykes the porphyritic parts occur in zones not far from the contacts while the centres are free of phenocrysts.

In the central part of the dyke of Pârdlitt (fig. 13) relicts of the ophitic texture are well preserved. The tabular plagioclase crystals have basic cores, which are commonly saussuritised, and narrow acid margins. In places the crystals are completely unaltered and filled with minute inclusions of ore. Occasionally aggregates which consist of small equidimensional grains of plagioclase occur with the same shape and size as the tabular crystals. Evidently the former originated as a result of recrystallisation of the latter. Clinopyroxene was only found in a few thin sections as relicts in large crystals of colourless hornblende which usually occupies a large part of the interstices between the plagioclase laths. Although the possibility cannot be ruled out that some of the original pyroxene was replaced by the colourless hornblende during the cooling immediately after the intrusion of the dyke, it is probable that much of this type of hornblende is of metamorphic origin.

In the interstices between the feldspar laths there are also aggregates of biotite, bluish green hornblende with a lower birefringence than the colourless variety, and ore. These aggregates encroach upon the feldspars and replace the colourless hornblende. Different stages of this replacement can be distinguished. An incipient stage is represented by the formation of rims of bluish green hornblende along the grain boundaries of the colourless variety. Careful observation shows that these rims are associated with the occurrence of biotite. In those parts of the rock where mica is not present there are no bluish hornblende rims, so that it can be concluded that they are not the result of reaction between the plagioclase and the hornblende, but are related to alkali metasomatism. In more advanced stages the rims are wider and it can be seen that they have replaced part of the adjacent feldspar, which locally is fragmented into aggregates of small equidimensional grains. Occasionally there is a still 
later generation of hornblende replacing the two earlier types of hornblende. This generation is colourless and has a relatively high birefringence, while polysynthetic twinning is strongly developed; possibly this is an actinolitic or a cummingtonitic variety.

The margins of the dyke are strongly recrystallised for a few centimetres. The recrystallised margins consist of an aggregate of slightly elongate to equidimensional plagioclase crystals averaging $0.1 \mathrm{~mm}$, irregular crystals of green hornblende and biotite flakes, all of which are oriented obliquely to the contact of the dyke. Microclines from the country rock granite can be seen to have grown into the dyke. Those parts of the crystals replacing the dyke rock contain abundant inclusions of the mafics mentioned above. Along both sides of and close to the contacts of the dyke there are thin crush zones postdating the microclinisation, and along the zones within the dyke there are locally concentrations of biotite. A few centimetres from the contact the grain size of the dyke rock increases gradually and the tabular habit of the plagioclases becomes more and more distinct. Apparently the recrystallisation was less effective there. Within a few decimetres of the margin the dyke rock is still finer-grained than in the centre and this feature is obviously the result of chilling.

On Pârdlitt there is a thin sheet of pyroxene-bearing diorite which can be followed into a later belt of lineated granite (see fig. 30). Outside the belt there are no indications of deformation in the diorite. Green hornblende forms irregular deeply embayed crystals a few millimetres in size, each of which contains small relicts of clinopyroxene. Relicts occurring within the same hornblende crystal always show optic continuity, suggesting that most of the hornblende originated at the expense of clinopyroxene. The original tabular habit, $1-2 \mathrm{~mm}$ in size, of only a few of the plagioclase crystals is still recognisable, as these crystals were mostly broken down into smaller sub- or anhedral crystals a few tenths of a millimetre in size. This feature is rare and only locally observed in the pyroxene-bearing diorites from elsewhere and demonstrates a degree of recrystallisation in this locality which is slightly higher than usual in the area between Pârdlît and Takissoq.

Within the belt of lineated granite at an intersection with a strongly folded metadolerite (fig. 35), the diorite is clearly foliated and finergrained than outside the belt. Small oriented hornblende aggregates are common and the rock is very similar in texture to the thinner metadolerite dykes to be described in a subsequent section. Relicts of pyroxene do not occur, but many hornblende crystals contain in their cores inclusions of quartz. The occurrence of the hornblende aggregates is surprising and it is tempting to explain this as the consequence of deformation and 
stretching of the sheet by means of which part of the hornblende was concentrated in aggregates. It is however more probable that there had been a considerable number of pyroxene phenocrysts which were broken down and altered into hornblende aggregates.

Amphibolitic sheets and dykes are common on Niaqornap nunâ in the Big-feldspar granite (variety 5) not far from its southern margin. Field observations showed that they are the continuations of sheets and dykes of pyroxene-bearing diorite occurring in the neighbouring granite. Unlike the pyroxene-bearing diorites outside the Big-feldspar granite the amphibolite bodies are generally deformed and boudinée especially in places where the foliation of the granite is pronounced. Here and there big feldspars can be seen protruding into the amphibolites.

The amphibolites generally show crystalloblastic texture. There are very few relicts of clinopyroxene. Occasionally tabular plagioclase crystals have been preserved; these are weakly zoned or homogeneous. Locally blastophitic texture can still be recognised.

\section{Net-veining}

The pyroxene-bearing diorites show a type of net-veining identical to that of the net-veined diorites (see fig. 14), except that it is generally not developed to such a high degree and is also not of such consistent distribution. The net-veins clearly replace the diorite as can be seen along the margins of the bodies where the contacts of the replaced diorite with the country rock lie in line with those of the unaffected diorite.

Here and there close to the contacts of the bodies the diorite is foliated and has a crystalloblastic texture. The foliation is either parallel or slightly oblique to the margins. The effects of recrystallisation decrease towards the centre of the bodies so that the original igneous texture becomes more apparent. This transitional zone is at most a few centimetres wide. Large parts of the foliated margins were replaced by granodioritic material with no resulting mineral orientation, suggesting that crystallisation in the granodiorite postdated the deformation in the dykes.

In two localities there are small oval-shaped, steep or vertical pipelike bodies of granitic material, which is identical to that of the net-veins, in the diorite.

The net-veins predate the migmatisation phenomena observed in the pyroxene-bearing diorites; leucocratic veins associated with this migmatisation can be seen cutting net-vein material in fig. 14 . 


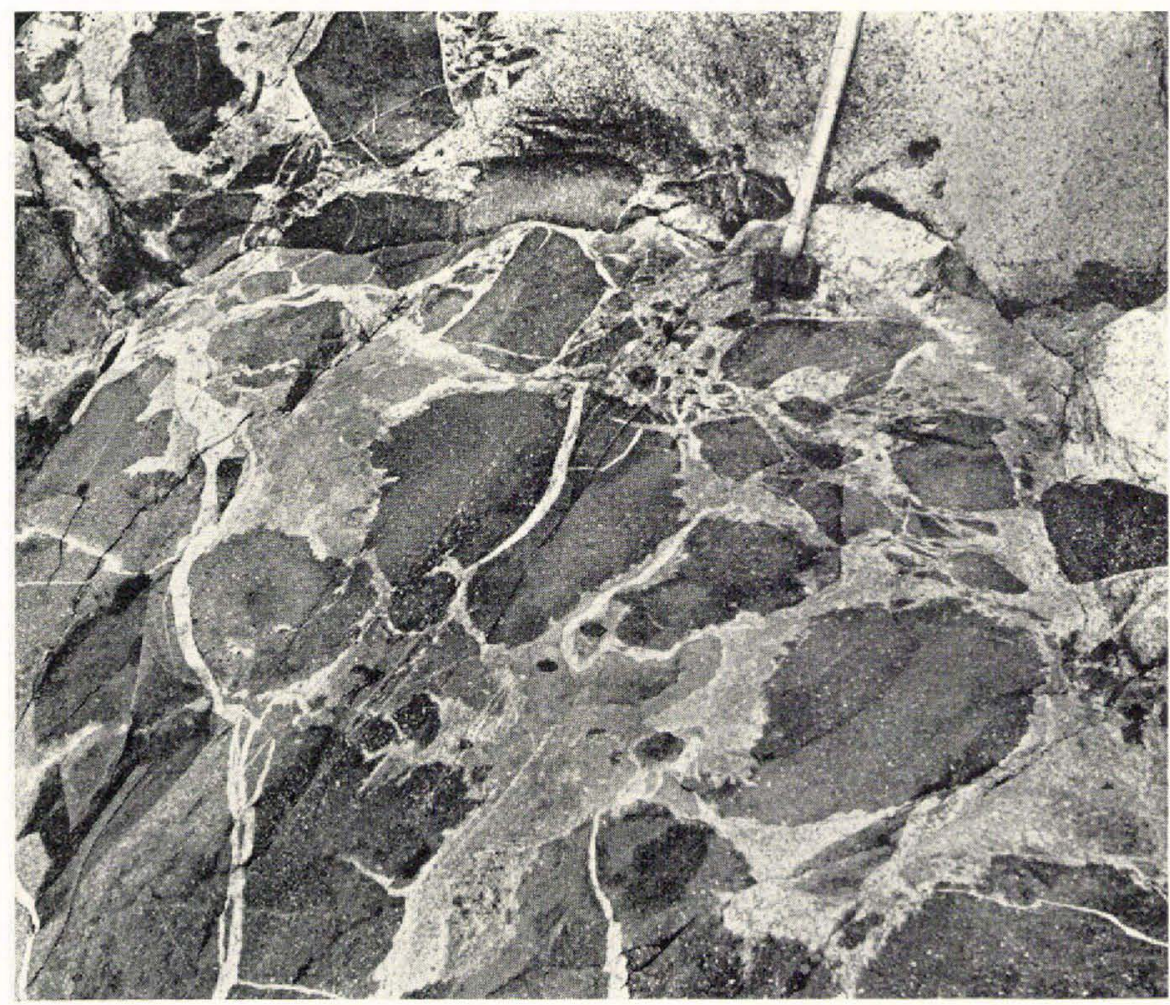

Fig. 14. Pyroxene-bearing diorite with typical internal net-veining (in the centre). In the upper left corner country rock granite has agmatised the diorite producing angular fragments. From the agmatising granite veins penetrate deeper into the diorite crosscutting the net-veins. These granite veins may be very irregular (close to the centre) when proceeding through the net-veins, but within the diorite fragments they are more regular. This might suggest that the net-veins were partly mobile when the country rock granite started to agmatise the diorite.

\section{Hornblendites}

There are a few basic bodies which have a similar position in the chronology as that of the pyroxene-bearing diorites. For this reason these bodies are described briefly in the present section.

On the south-eastern side of Julianehåb peninsula there is a $3 \mathrm{~km}$ long body of hornblendite which varies in width between $30-100 \mathrm{~m}$, trends NE and has a vertical attitude. In its continuation to the southwest on Kilagtoq island there is a hornblendite dyke which continues inland for $500 \mathrm{~m}$. Other bodies, often irregular in shape, have been recorded on Hollænder $\varnothing$ and Qaersuarssuk. The rock characteristically consists of short tabular crystals of hornblende, $0.5-1 \mathrm{~cm}$ in length, 
closely packed in a fine-grained aggregate of hornblende and plagioclase. The structures in these bodies have not been investigated in detail.

Only the south-easternmost part of the body first mentioned from Kilagtoq has been investigated microscopically. The rock consists almost exclusively of hornblende. Large crystals of green hornblende, up to $4 \mathrm{~mm}$ in size and usually filled with finely divided ore, are regularly distributed in a fine-grained matrix. Parts of the crystals are discoloured to a light greenish hornblende which is free of ore inclusions. Some hornblendes are sieved by small crystals of the light coloured hornblende. The matrix consists mainly of anhedral crystals of the light coloured variety, which locally contains small relicts of a green hornblende identical to the megacrysts. Clinopyroxene, containing a great deal of finely divided ore, commonly occurs as relicts in the larger hornblende crystals. Accessories are normally zoned plagioclase, biotite which is locally altered to prehnite, epidote, apatite and ore. 


\section{HYPERSTHENE GABBROS}

\section{Field description}

There are several bodies of hypersthene gabbro arranged in an ENE-trending belt between Avatarmiut and Sdr. Igaliko (plate 3). Four occurrences are situated within the Big-feldspar granite and three within (Julianehåb peninsula, NesBiTT, 1961) or close to the contacts of the Julianehåb-Igaliko granite body (variety 4). Three other bodies in the eastern end of the belt have been mapped by BERRANGÉ (1966) and S. Andersen. These gabbros show a close similarity to the noritic gabbros described by Bridgwater (1963), which are associated with the "New granites" from Sydprøven and farther south-east.

The gabbro bodies of the area investigated generally have a marginal phase, at least $10 \mathrm{~m}$ wide, of medium-grained diorite in which aggregates of hornblende, several millimetres in size, are regularly distributed. Farther from the contacts the rocks grade into gabbro. Layering is a very common feature in the bodies, mostly marked by a compositional variation, and in places differences in grain size. The best examples occur on the eastern side of Niaqornap nunâ, and these have been chosen for detailed description.

In one locality the following situation is displayed in a well exposed coastal section. The contact trends $\mathrm{N}-\mathrm{S}$ and is vertical. The marginal phase of diorite is about $15 \mathrm{~m}$ wide. Inwards there is a one metre wide zone of finely banded anorthositic rock in which dark layers, 0.5 to $5 \mathrm{~cm}$ wide and averaging $0.8 \mathrm{~cm}$, alternate with leucocratic plagioclase-rich bands, $2-3 \mathrm{~cm}$ wide. Locally graded bedding is displayed; the "way up" is towards the west and away from the dioritic marginal phase. The banding is almost vertical. This one metre zone varies in thickness. The observations show that this variation in thickness is the result of "erosion" by later magma. In places where the zone is very thin its banding is clearly cut off by more inward-lying material which forms an $11 \mathrm{~m}$ wide zone of medium-grained, banded, gabbro-anorthositic rock. Graded bedding is also displayed and the way up is in the same sense as in the layer just mentioned, i.e. towards the west. Towards the top of the zone cross-bedding occurs. Still farther to the west there is a very 
basic and coarse-grained gabbro in which strongly cross-bedded layering is developed; its way up is also towards the west. Thin veins of the basic gabbro penetrate the gabbro-anorthositic and anorthositic zones and the dioritic marginal facies. It is remarkable that all the layering structures are vertical, suggesting that their attitude, which was probably originally horizontal, has been changed considerably since the intrusion of the body. Another significant feature is the succession of different rock types. First the dioritic marginal phase was emplaced, followed by the more anorthositic rocks and finally the basic gabbro; the mutual contacts between the successive intrusive phases do not exhibit chilling phenomena.

The rocks described from this locality form part of a $400 \mathrm{~m}$ long and $80 \mathrm{~m}$ wide zone containing the same succession of rocks as just described. The outer contact of the dioritic marginal phase with the country rock has been observed in several places and is clearly the original contact. On the western side of the zone the layered gabbro lies in contact with the Big-feldspar granite (variety 5). The layered structures in the gabbro are truncated by the granite the contact of which is clearly abnormal. The rocks on both sides of this contact show however no signs of low temperature alteration or of deformation. In view of this and the vertical position of the banding with its erosion structures it is necessary to conclude that this $400 \mathrm{~m}$ long fragment was detached from a one time larger body and disoriented possibly as a result of mobility in the surrounding granodiorite after the emplacement of the gabbro.

To the south another gabbro pluton occurs of which more than $60 \%$ is under water. Along its margin, up to $100 \mathrm{~m}$ from its contacts, there is a great number of anorthositic inclusions, most of which are elongate and not longer than $1.5 \mathrm{~m}$. A few of the inclusions have distinct banding which is constantly parallel to their longest axes. Farther inwards the number of enclaves decreases until the gabbro is finally free of inclusions, leaving only small megacrysts of plagioclase regularly distributed. The intrusion of this pluton probably took place in two stages. During the first anorthositic gabbro with rather well developed layering was emplaced, while during the second there was intrusion of gabbro which picked up and fragmented the earlier anorthositic material.

\section{Microscopic observations}

Although the hypersthene gabbro bodies are in places strongly migmatised by the Big-feldspar granite (variety 5) and by the porphyritic to slightly porphyritic granodiorite (variety 4), they are usually remarkably little recrystallised, even in the dioritic marginal facies close to the contacts with the country rock granite. 
In the marginal facies plagioclase forms either large tabular crystals, a few millimetres in size, or smaller tabular crystals varying in size between 0.2 and $1 \mathrm{~mm}$. The megacrysts amount to at least $25 \%$ of the volume and are regularly distributed in the matrix formed by the smaller plagioclase crystals $(30 \%)$ and the mafics. Zoning is usually well displayed; the margins of the matrix plagioclase contain $20 \% \mathrm{An}$, while in the cores of the bigger crystals an $\mathrm{An}_{\mathbf{5} 0}$ composition has been recorded. Albite twins are very common, carlsbad twins are frequent and pericline and manebach twins are rare. Untwinned crystals are not present.

In places the most important mafic mineral is clinopyroxene forming subhedral crystals, a few millimetres in size, which as a rule are rimmed by a light coloured bluish hornblende. Some pyroxene crystals are filled with finely divided ore, while others show a very fine polysynthetic twinning. A large part of the clinopyroxene is partly or completely replaced by a fine-grained aggregate of colourless hornblende.

Biotite forms either irregular crystals, $1-3 \mathrm{~mm}$ in size, or outer rims surrounding some of the rims of bluish hornblende mentioned above.

In the fine-grained plagioclase matrix interstitial quartz is common. Microcline is present in small amounts and forms irregular crystals replacing plagioclase. Accessories are ore, titanite and apatite.

The gabbro of the central parts of the bodies is a coarse-grained rock consisting of hypersthene, olivine, hornblende, plagioclase, clinopyroxene, biotite, apatite and ore. The two most conspicuous constituents are hypersthene and hornblende, both of which form poikilitic erystals which reach up to $2 \mathrm{~cm}$ in size. They have very irregular outlines and are deeply embayed by euhedral plagioclase crystals.

Olivine rarely forms subhedral crystals up to $4 \mathrm{~mm}$ in size, but is usually in much smaller, anhedral grains with corroded outlines. A few are rimmed by hypersthene, which is clearly pleochroic (pink to light greenish grey) .The hypersthene crystals vary in grain size and contain numerous inclusions of olivine and a few of plagioclase. Plagioclase always forms euhedral crystals and varies in size between $1 \mathrm{~cm}$ and a few tenths of a millimetre. Oscillatory and normal zoning is well displayed; the most calcic centres recorded are $\mathrm{An}_{50}$ and the outermost rims are ca. $\mathrm{An}_{28}$. Twinning is very common; the same twin laws were observed as in the dioritic margin of the bodies. Locally the plagioclase is saussuritised. A colourless clinopyroxene commonly occurs as relicts in hornblende and has a very regular distribution.

There are two varieties of hornblende, the older of which is brown in colour; the younger is light green and replaces large parts of the older variety. The brown hornblende contains numerous inclusions of olivine and plagioclase and occasionally it replaces hypersthene. There are also two varieties of biotite: a reddish brown and a light green 
variety, the latter of which is the youngest. The amount of biotite is usually small and it varies in amount in different places. Its crystals are very irregular and reach up to $5 \mathrm{~mm}$ in size. Biotite replaces all other constituents. Ore and apatite are accessories. Occasionally apatite forms stout prisms with a length up to $0.5 \mathrm{~mm}$.

Secondary minerals are common in some places, especially in the body on an island east of Lille Tugtutôq which is strongly agmatised by the Big-feldspar granite. Most of the olivine and hypersthene are altered to a fine-grained aggregate of a mica-like mineral, presumably talc, and some ore. In other places, as in the body along Igaliko fjord, the hypersthene and olivine are replaced by fine-grained aggregates mainly consisting of a tremolitic amphibole with some light brown mica and ore.

Summarising, the following crystallisation sequence can be deduced. Olivine is evidently the oldest main mineral. The relations between hypersthene and plagioclase suggest that these largely crystallised simultaneously. The relations between hornblende and plagioclase are identical to those between hypersthene and feldspar. The common occurrence of clinopyroxene within hornblende suggests that the latter arose at least partially by replacement of clinopyroxene and that there was considerable overlap in crystallisation between clinopyroxene and the plagioclase. The age relations between clinopyroxene and hypersthene are not known. Biotite is clearly the youngest mineral. It is not known whether some of the hornblende and biotite crystallised from the magma or whether they originated during a later stage in the cooling history of the gabbros. It is probable that the light green hornblende and the green mica mentioned above originated during or in connection with plutonic activity after the cooling of the gabbros. The light green hornblende replaced the brown variety and also possibly some of the clinopyroxene. 


\section{METADOLERITES AND ASSOCIATED BODIES}

\section{Primary features, field relations and distribution}

In the nebulitic series (variety 1) and in the porphyritic hornblendebiotite granodiorite (variety 2) amphibolite dykes are generally common. At the outer parts of Bredef jord there is an important swarm of thin amphibolite dykes which can be followed for at least $25 \mathrm{~km}$ in an ENE to NE direction. Their spacing is slightly variable, but their frequency averages 20 dykes per kilometre. The width of the dykes ranges from a fraction of a metre to $10 \mathrm{~m}$, but it usually varies between $1 \mathrm{dm}$ and $2 \mathrm{~m}$. Typical intrusion features, such as apophyses, bifurcations, bayonet structures and en echelon arrangement are widespread. Connecting branches between the separate dykes are not uncommon. In some of these, which are regular, basic material of the same generation has clearly penetrated different sets of fractures. In other cases the fracturefilling pattern is irregular as can be seen for instance in fig. 39.

The dykes are generally deformed and in places folded (fig. 39, 40, 41). They are also disrupted and migmatised by the country rock granite (fig. 15, plate 1), but nevertheless they are usually continuous for at least several kilometres. The field relations of the amphibolite dykes are identical to those of the dyke swarms (the so-called 2nd period basic dykes) which occur with great regularity in the area between Julianehåb and Ûnartoq Fjord (Berrangé, 1966; Persoz, in press; Windley, 1966 a) and also around Sarqâmiut (T. C. R. Pulvertaft, personal communication). The country rock there is also very similar to that along the outer parts of Bredef jord and contrasts with the relatively homogeneous granites which generally predominate in the area between Julianehåb and Qagssimiut.

The western continuation of the marginal zone of the allochthonous granite of Julianehåb peninsula (variety 4) is well exposed on Pârdlitt and surroundings, and contains numerous basic inclusions. Some of these are irregular or oval-shaped and are identical to the metamorphosed volcanic and sedimentary supracrustal rocks from Mato island. Others are elongate and the fragments have straight parallel edges and irregular ends. In many places discontinuous rows of such straight-edged frag- 


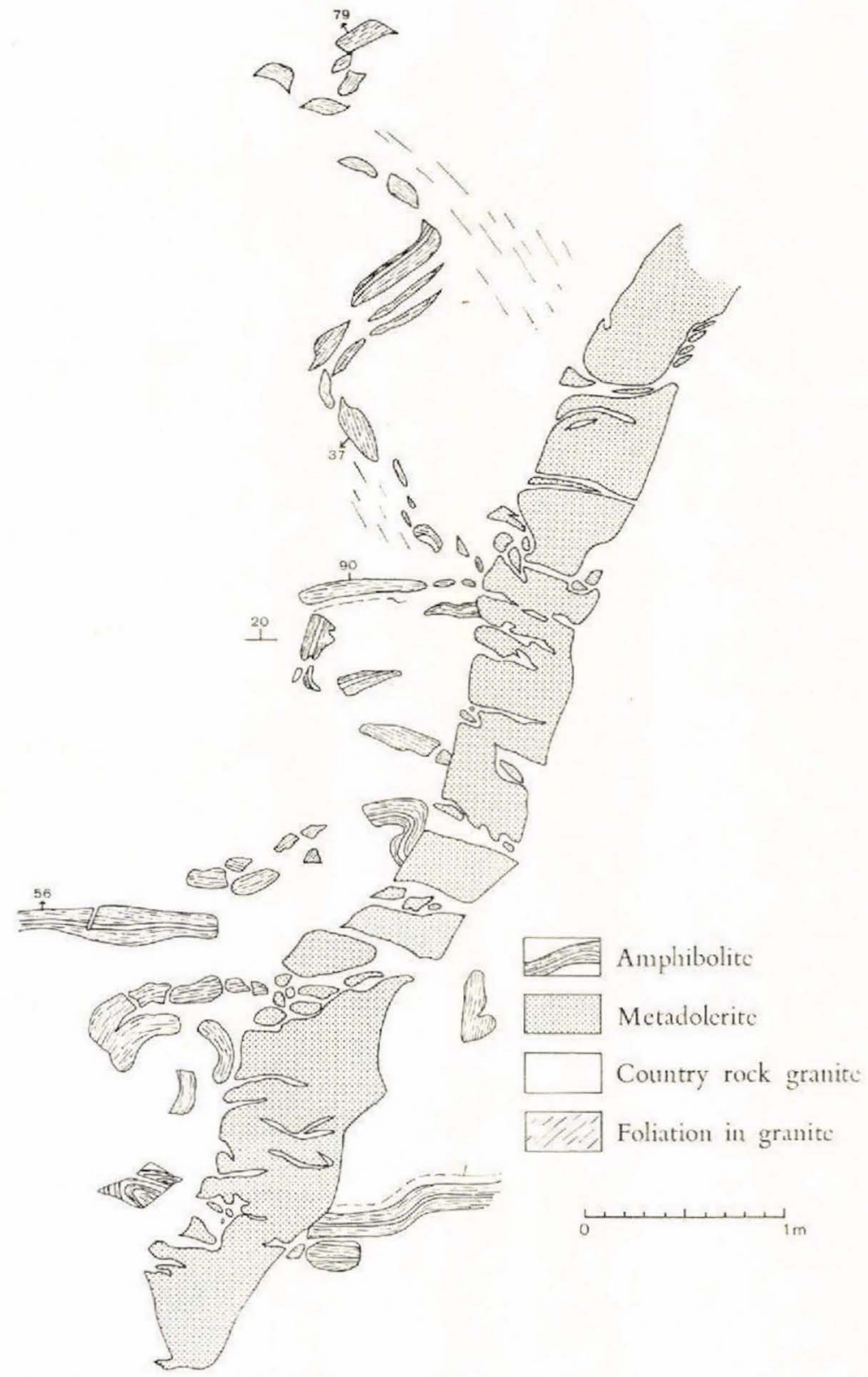

Fig. 15. Migmatised metadolerite crosscutting older structures mainly marked by $\mathrm{E}-\mathrm{W}$ trending folds in bands of amphibolite the origin of which is unknown. Eastern side of Qaersuarssuk, along Bredef jord.

ments can be followed for some tens of metres (fig. 16). On Pârdlit there are a few of these in the granite close to the contacts of a big enclave of amphibolitic supracrustal rock. Within the enclave in line with the above rows continuous amphibolite dykes occur crosscutting the enclave 


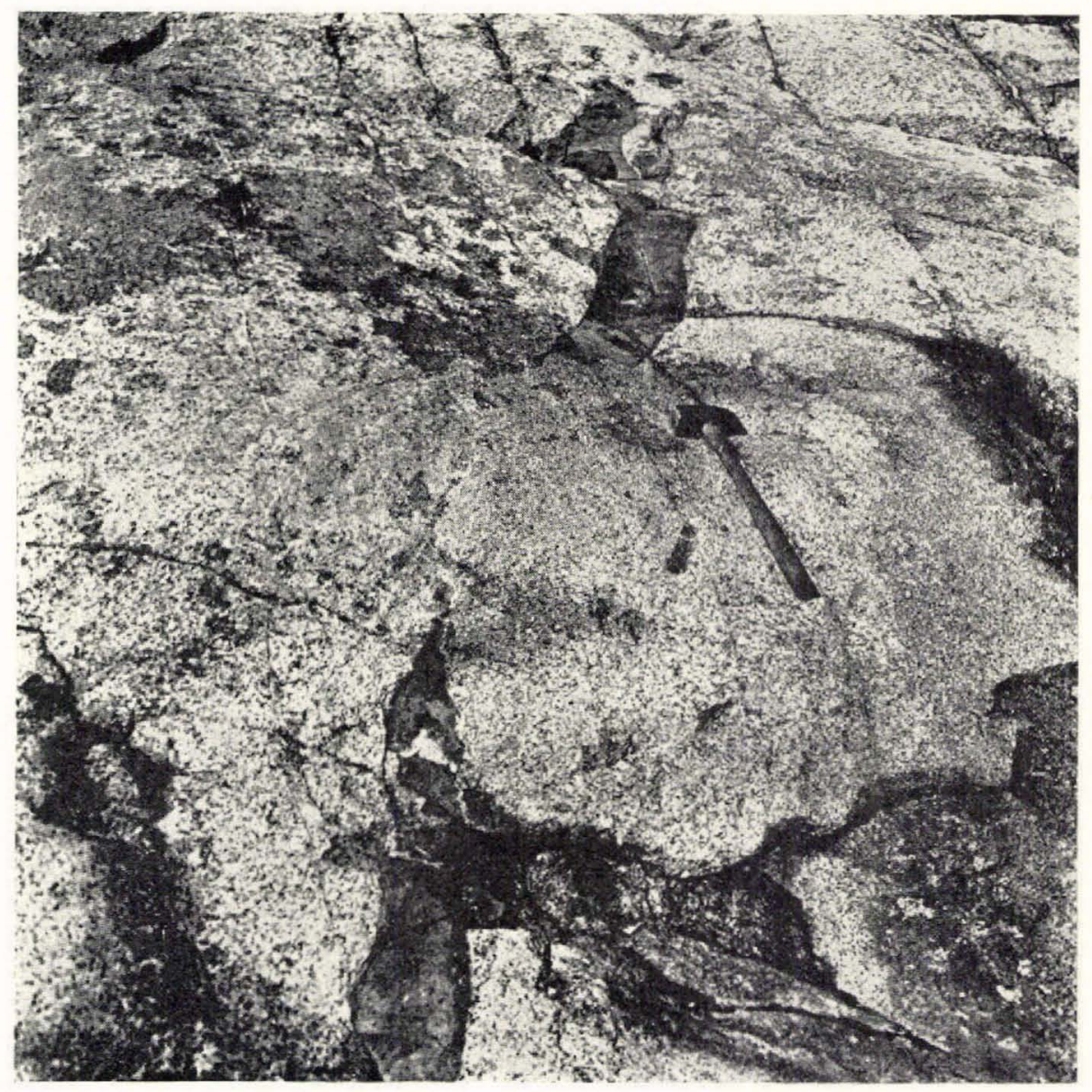

Fig. 16. A row of straight-edged metadolerite fragments in marginal facies of allochthonous granite body belonging to variety 4. Pârdlît island.

of supracrustal rock (fig. 30). Also in other places crosscutting relationships of the straight-edged fragments to enclaves of amphibolitic supracrustal rock were recorded, an example of which is shown in fig. 17. This figure is from a locality along the shore at the south-west side of Julianehåb peninsula. Along a NE-trending line landwards the straightedged fragments reappear regularly for a distance of $300 \mathrm{~m}$. However, the fragments in the granite occupy only $20 \%$ of the length of this line. Observations elsewhere suggest that the frequency of the fragments is much smaller. The longest fragment observed has a length of $25 \mathrm{~m}$. From this an apophysis was seen to penetrate the granite (fig. 18). These relationships demonstrate that the straight-edged amphibolite fragments are relicts of basic dykes. Their frequent occurrence in a broad area suggests that they originally belonged to a swarm of dykes. 

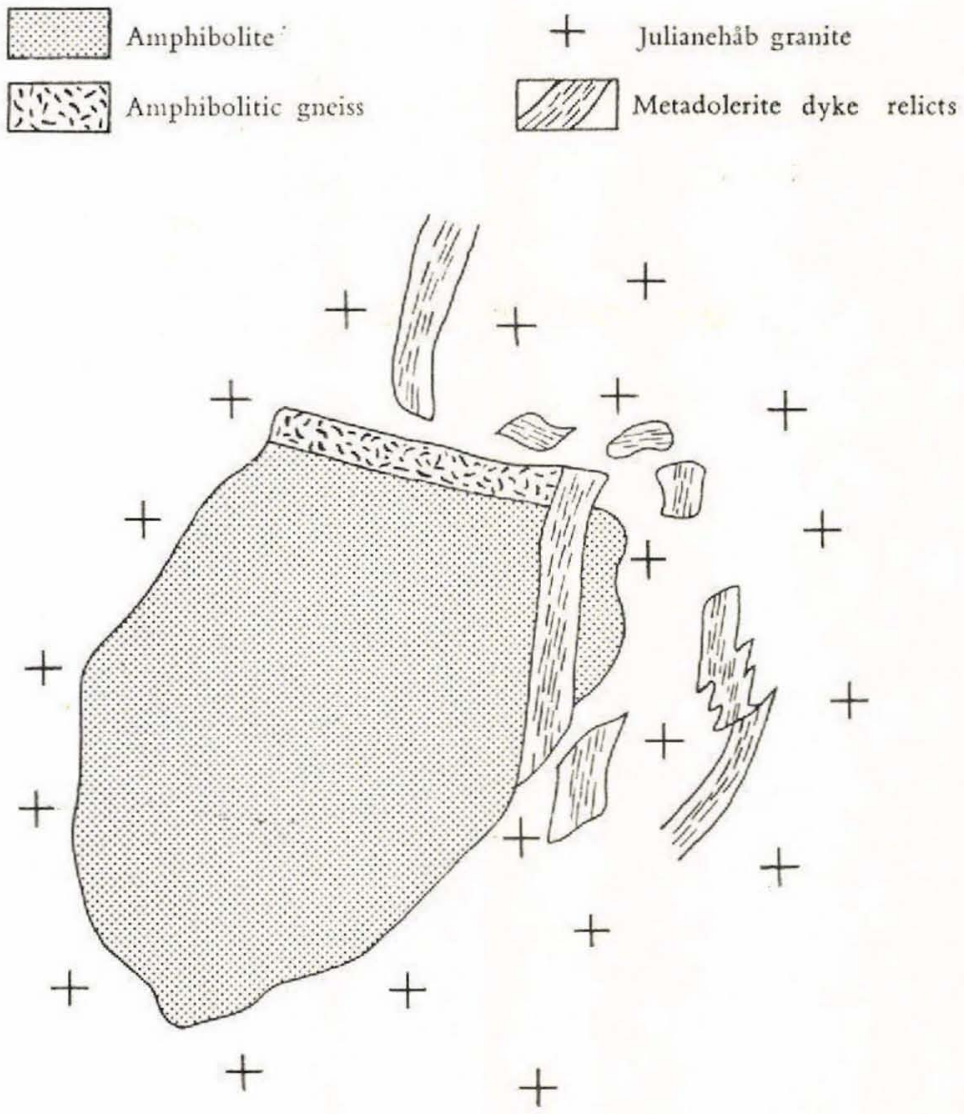

Fig. 17. Inclusion of amphibolitic supracrustal rock crosscut by a post-granitic metadolerite (ca. $10 \mathrm{~cm}$ wide) which was fragmented after its intrusion. South-west side of Julianehåb peninsula.

Most of the dyke fragments are oriented slightly oblique to the granite foliation but have themselves an internal foliation parallel to this. Occasionally the fragments are boudinée (fig. 19). In a few localities on Pârdlit there are a few strongly folded portions of a basic amphibolite dyke.

The measurements of structural planar elements along Torssukátak fjord revealed the presence of an ENE-trending antiform the core of which is occupied by an allochthonous granite (variety 4), while in the limbs bands of gneiss are intercalated with granite. Deformed amphibolite dykes are frequent in the limbs and in the core there are occasional scattered dyke fragments which are identical in appearance to those of Pârdlit. The dykes at the outer part of the fjord constitute the continuation of the swarm of Bredef jord. These observations show that in a NW direction, about perpendicular to the trend of the Bredef jord swarm, amphibolite dykes remain frequent, unless particular later plutonic phenomena disturb the picture of the original distribution. 


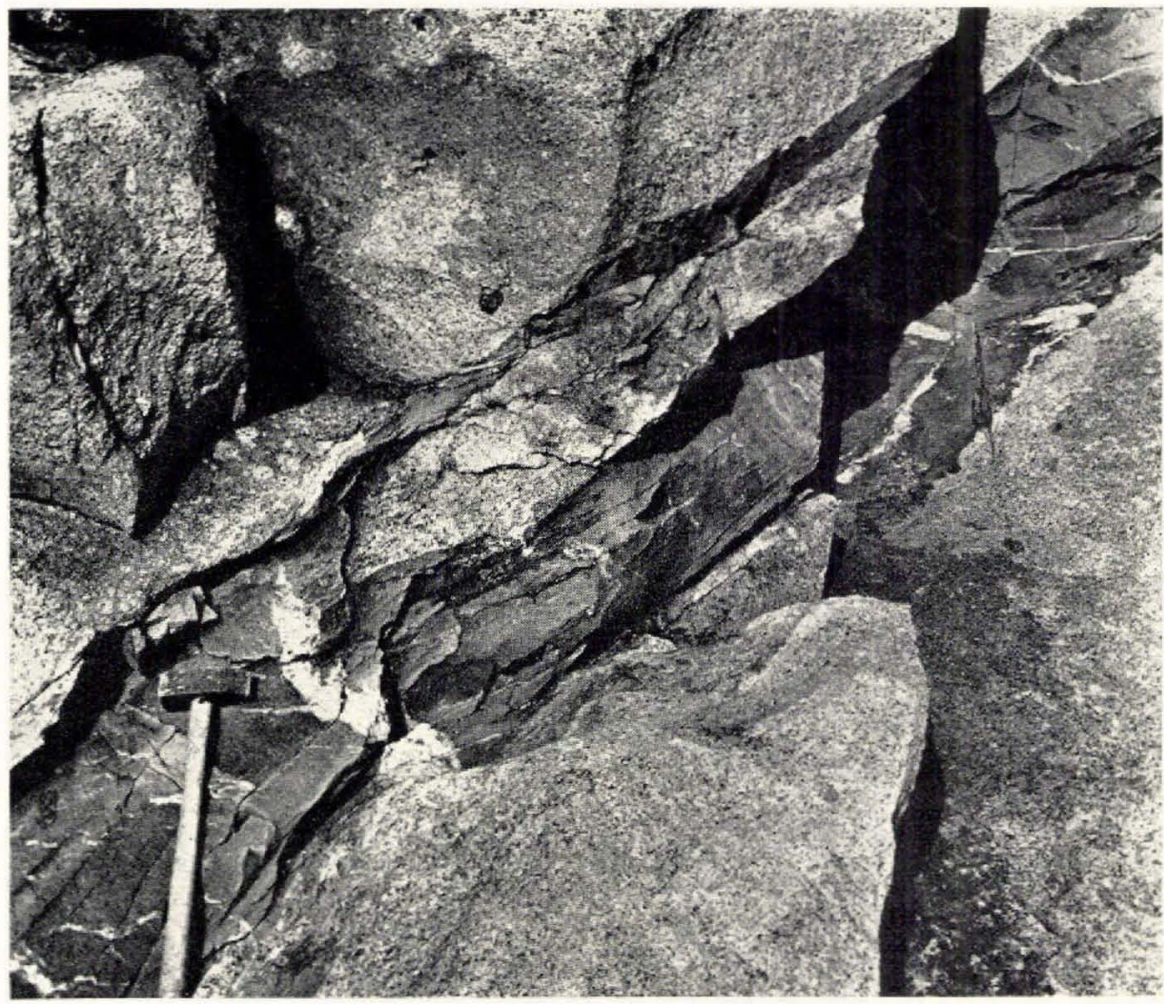

Fig. 18. Part of a $25 \mathrm{~m}$ long fragment of metadolerite sending out an apophysis into the host granite (variety 4). Pârdlit island.

The general continuous character of the disrupted amphibolite dykes of Bredefjord and the extreme spacing of the amphibolite dyke fragments on Pârdlit and Julianehåb peninsula reflect differences in degree of stretching in the host granite during plutonic events subsequent to the emplacement of the dykes.

Along the northern side of Bredef jord a few small, elongate bosslike intrusions occur varying in length between 100 and $200 \mathrm{~m}$ and trending ENE or N-S. They consist of basic rock and have chilled margins $5-10 \mathrm{~m}$ wide. Between two of the bosses, which lie $200 \mathrm{~m}$ from each other, there is a fracture-filling system, which is so irregular that it seems that the basic material from the bosses penetrated a mylonitic breccia in the granite (see fig. 20). From the bosses amphibolite dykes penetrate the country rock. These are identical to the other amphibolite dykes in this area and they also have the same direction, suggesting that the bosses belong to the same phase of intrusive activity that produced the dyke swarm which extends along both shores of Bredef jord. 


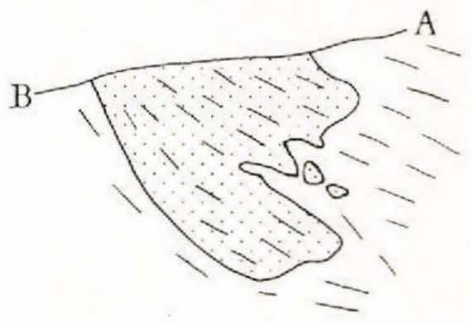

1/7, Foliated granite

\%etadolerite

ㅈ.
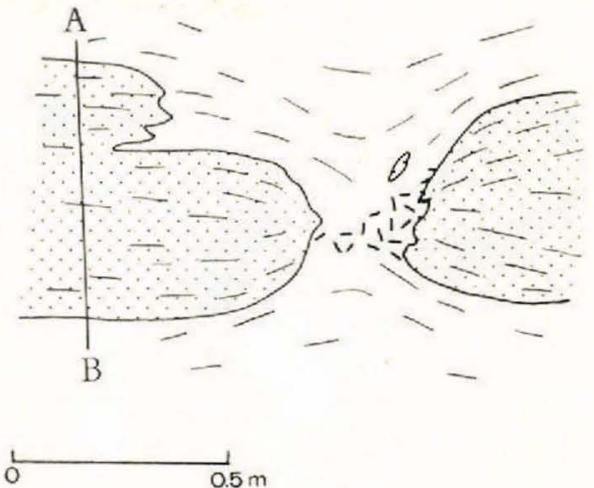

Fig. 19a.

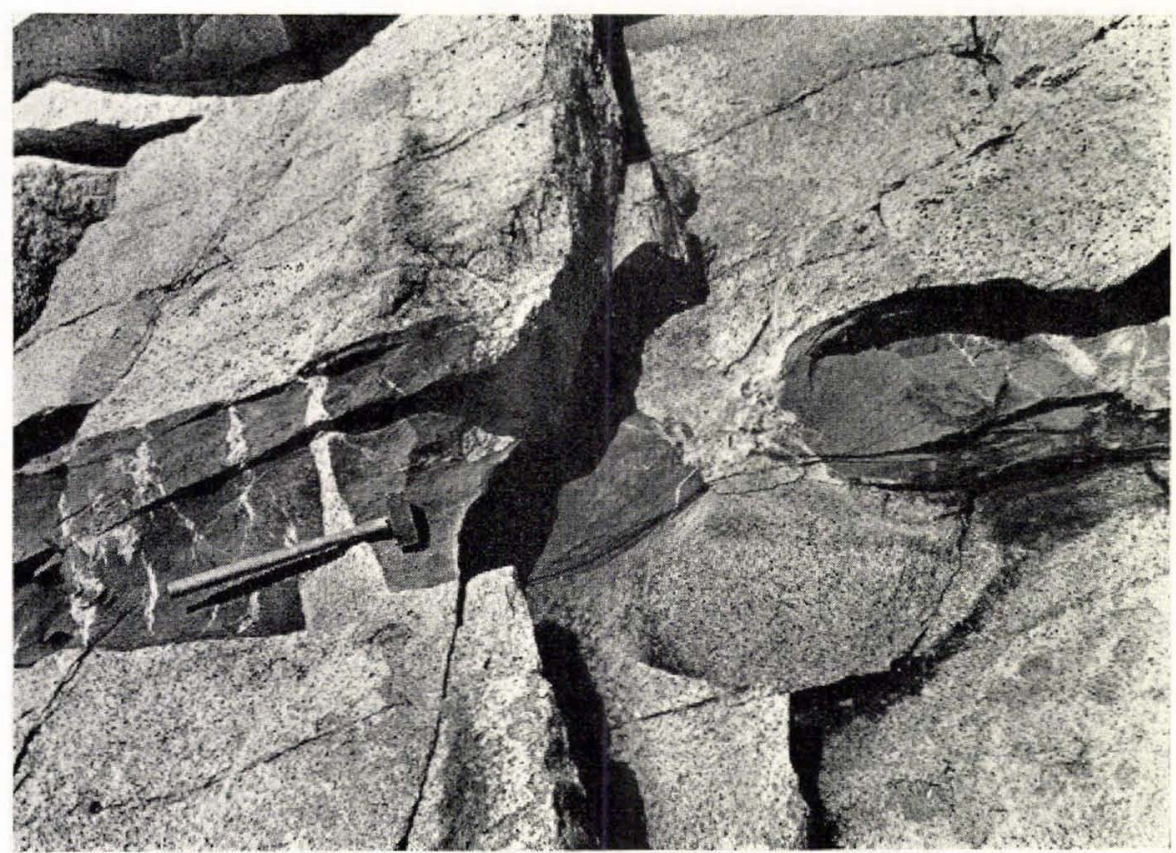

Fig. 19 b.

Fig. 19. Boudinage in the same metadolerite fragment as fig. 18 with pegmatite filling. The granite foliation which is continuous with the internal foliation in the dyke relict (see drawing) is clearly infolded between the two fragments. Pârdlit island. 


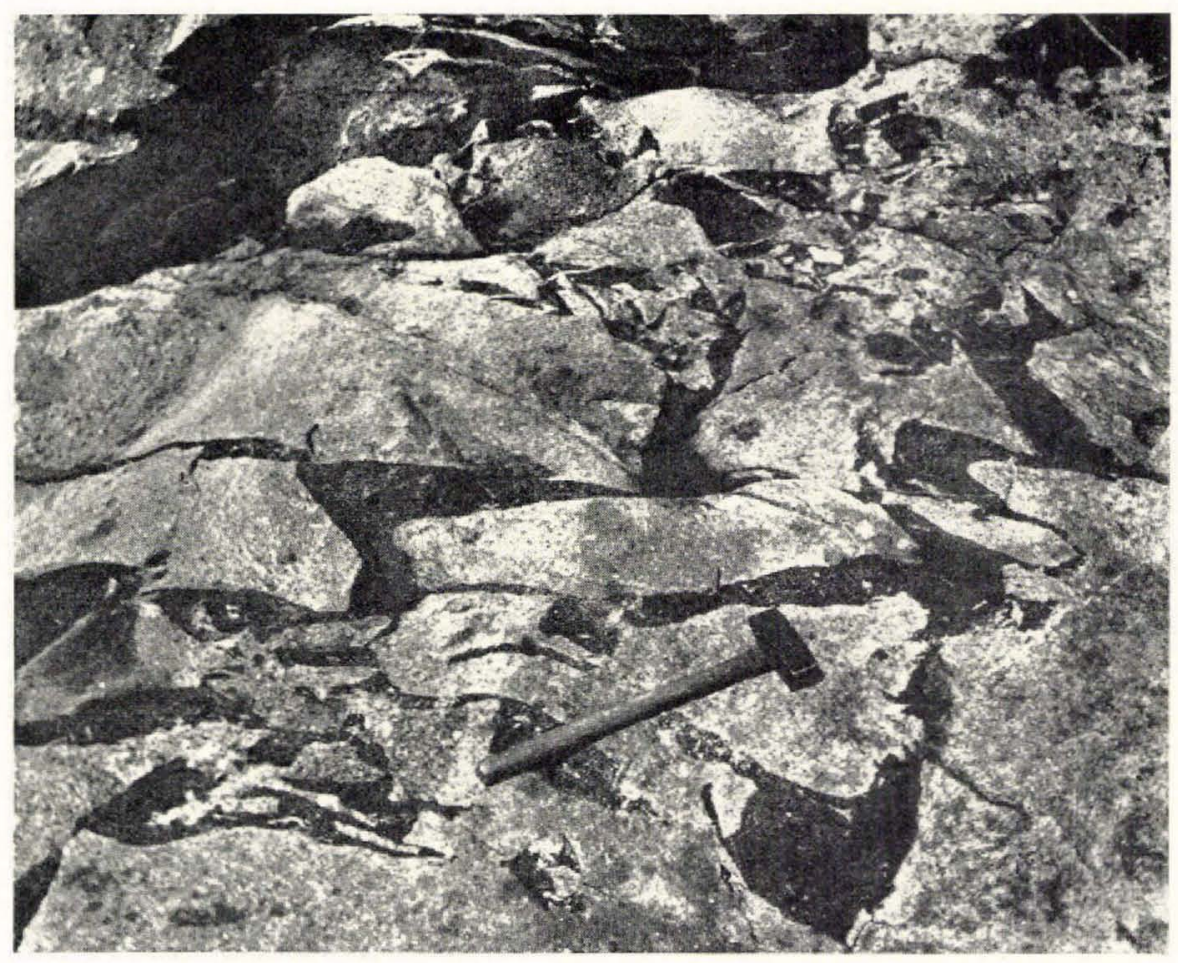

Fig. 20. Irregular fracture-filling pattern between two boss-like bodies of metagabbro. Qaersuarssuk, north-west side of Bredef jord.

\section{Internal structures and microscopic observations}

Three examples will be described. The first is from a $7 \mathrm{~m}$ wide amphibolite dyke from Bredefjord, the second is from the irregular fracture-filling system between the two boss-like bodies just described and finally a description will be given of the thinner dykes of Bredef jord and the straight-edged fragments from Pârdlit and surroundings.

The marginal zone of the wide dyke of Bredefjord consists of a fine-grained aggregate, with grain size averaging $0.2 \mathrm{~mm}$, of irregular crystals of green hornblende, slightly elongate plagioclase and flakes of biotite. There is a weak mineral orientation of the plagioclase and biotite parallel to the contacts of the dyke. In a zone between $3 \mathrm{~cm}$ and about $1 \mathrm{~m}$ from the margins elongated hornblende aggregates occur regularly distributed in the amphibolitic ground mass. More towards the centre the aggregates disappear. Foliation remains visible up to $1 \mathrm{~m}$ from the margin. Occasionally a type of banding parallel to the contacts is displayed marked by thin alternations in the grain size between 0.5 and 
$0.1 \mathrm{~mm}$. In the foliated parts of the dyke the plagioclases $\left(\mathrm{An}_{25}\right)$ are unzoned or only weakly zoned and even larger crystals are practically homogeneous. The centre of the dyke has an average grain size below $1 \mathrm{~mm}$ and the following mineralogical composition: hornblende $45 \%$, plagioclase $35 \%$, clinopyroxene $13 \%$, biotite $6 \%$ and accessories $1 \%$. Occasionally there are small areas in which tabular plagioclase crystals up to $5 \mathrm{~mm}$ and with irregular outlines are preserved. Outside these areas the plagioclases are slightly elongate or equidimensional averaging $0.4 \mathrm{~mm}$. Green hornblende is in the form of anhedral grains, regularly distributed. Locally this mineral shows a tendency to concentrate in small aggregates. Clinopyroxene occurs either in the hornblende crystals or in aggregates of several irregular grains. Biotite is regularly distributed forming irregular crystals and is partially altered to prehnite and optically negative penninite. Epidote, apatite and rutile are accessories. The ore content is exceptionally low.

The rock of the irregular fracture-filling system between the two boss-like bodies illustrated in fig. 20 has the following mineralogical composition: hornblende $54 \%$, plagioclase $21 \%$, biotite $17 \%$, clinopyroxene $6 \%$ and accessories $2 \%$. Elongate areas, 1-2 $\mathrm{mm}$ long, with random orientation and almost exclusively consisting of equidimensional plagioclase crystals, averaging $0.3 \mathrm{~mm}$, occur regularly distributed in a mafic aggregate which forms a continuous and irregular network enclosing the plagioclase aggregates. The mafic aggregate is mainly made up of anhedral grains of green hornblende with an average size of $0.3 \mathrm{~mm}$, between which there are regularly distributed biotite flakes. Larger hornblende crystals a few millimetres in size, are however common and contain large relicts of clinopyroxene which are usually filled with finely divided ore and occasionally show polysynthetic twinning. Accessories are ore and apatite. The texture of the rock is typically blastophitic and it is clear that originally the rock was medium-grained. There is a great similarity between this rock and the dyke just described; the latter is only slightly richer in plagioclase.

The narrower dykes from Bredef jord and the dyke fragments from Pârdlitt and surroundings characteristically contain a considerable number of well oriented hornblende aggregates which reach a length of $2 \mathrm{~cm}$. The degree of concentration of these varies in different dykes. They are usually concentrated in the centres, even in those dykes a few centimetres wide. In a few dykes the concentrations of the aggregates have a random distribution.

The matrix is fine-grained and consists of more or less evenly distributed green hornblende and plagioclase in a schistose association. The average grain size is $0.5 \mathrm{~mm}$ or less. Biotite, the third main constituent is in the form of oriented flakes. Relicts of clinopyroxene are widespread. 
A large part of the hornblende associated with the pyroxene relicts is almost colourless and sieved by small quartz inclusions.

Elongate aggregates of green hornblende occur regularly distributed and are oriented parallel to the internal foliation. The hornblende crystals also show a tendency to be arranged in trails of several millimetres in length.

Careful observations in some of the dykes and the fragments showed that the first impression, that the hornblende crystals of the matrix are small $(0.5 \mathrm{~mm}$ or smaller), is not always correct. In several places apparently isolated hornblende fragments show optical continuity and there are larger crystals, a few millimetres in size, with deeply embayed outlines. The embayments are occupied by aggregates of elongated plagioclase crystals which are oriented parallel to the foliation. These hornblende crystals lie oblique to the foliation in contrast to most of the small hornblendes which usually show a distinct dimensional orientation parallel to it. Apparently the deformation of the rock fabric did not break down the larger hornblende crystals. The frequent occurrence of pyroxene relicts in the latter suggests that they are pseudomorphs after pyroxene and their deeply embayed form evidently represents a relict of the ophitic texture in the original rock; these features are however rare. As a rule the deformation and recrystallisation destroyed most of the original textures and the original grain size.

Microcline is widespread occurring either as interstitial grains of the same size as plagioclase or as elongate porphyroblasts oriented parallel to the foliation and including a great number of crystals of hornblende and biotite.

Accessories are quartz, apatite, orthite and titanite. The last mineral is clearly of secondary origin, as it usually forms irregular grains along the grain boundaries of the crystals of the hornblende aggregates. 


\section{CHEMISTRY OF SOME BASIC AND INTERMEDIATE INTRUSIVES}

Chemical analyses have been obtained of 6 samples of different intrusive bodies. One is of a metadoleritic dyke, one of a hypersthene gabbro and four of bodies of pyroxene-bearing diorite (table 3). For comparison three other analyses are also presented in the table. Two of these are of hypersthene gabbro and diorite from a pluton north of Narssarssuaq (Walton, 1965). The third analysis is of a hypersthene gabbro from a pluton near Frederiksdal (W. S. WATT, personal communication).

The analyses have been plotted on a si-variation diagram (fig. 21) using Niggli values (Burri and Niggl, 1945; Burri, 1959). The si values in the diagrams cover only a restricted part of the variation found in other magmatic provinces. However the si-variation diagram does show the following features: the fm (iron-magnesium) values are much higher than those of $c$ and al, which are in similar proportions; the rocks are also relatively poor in alk. This configuration over the range si 100 to 150 is typical of the calc-alkali series.

The hypersthene gabbros and the metadolerite from Bredef jord can be classed in NIGGLI's gabbroic magma-type, the pyroxene-bearing diorite with doleritic affinities (3) and one of the diorites (4) with the gabbrodioritic type, and the two remaining diorites with the dioritic magma-type of the calc-alkali series (BURRI, 1959).

In the QLM diagram (fig. 22) the plotted analyses fall in the PFM triangle corresponding to a normative paragenesis pyroxene-feldsparolivine and with a saturation coefficient $(\alpha)$ between 0 (the line MF) and 1 (the line PF). This triangle can be correlated with the olivine tholeiite group of Yoder and TILLEY (1962, fig. 2). One of the samples contains normative quartz and another normative nepheline. The reason that this is not reflected in the plots in the QLM diagram is the convention followed with the calculation of normative diopside to produce the same amount of Wo and $(\mathrm{En}+\mathrm{Fs})$. Under certain circumstances this procedure can result in the production of nepheline in rocks with a saturation coefficient which is smaller than 1. Another factor which can cause 
Table 3. Chemical data of some basic to intermediate intrusives.

\begin{tabular}{|c|c|c|c|c|c|c|c|c|c|}
\hline $\begin{array}{c}\text { No. } \\
\text { GGU no. }\end{array}$ & $\begin{array}{c}1 \\
33776\end{array}$ & $\begin{array}{c}2 \\
33751\end{array}$ & $\begin{array}{c}3 \\
54983\end{array}$ & $\begin{array}{c}4 \\
33797\end{array}$ & $\begin{array}{c}5 \\
56647\end{array}$ & $\begin{array}{c}6 \\
33760\end{array}$ & $\begin{array}{c}a \\
51304\end{array}$ & $\begin{array}{c}\mathrm{b} \\
55189\end{array}$ & $\begin{array}{c}c \\
55166\end{array}$ \\
\hline $\mathrm{O}_{2}$ & .71 & 49.57 & 49.61 & .13 & 52.15 & 52.44 & 49.8 & 49.83 & 50.25 \\
\hline $\mathrm{l}_{2} \mathrm{O}_{3}$. & 15.26 & 13.43 & 16.63 & 16.79 & 15.66 & 16.16 & 17.7 & 10.80 & 15.50 \\
\hline $\mathrm{e}_{2} \mathrm{O}_{3}$ & 1.81 & 2.56 & 2.36 & 1.99 & 3.51 & 3.18 & 0.6 & 4.10 & 4.36 \\
\hline $\mathrm{FeO}$ & 7.30 & 5.89 & 8.04 & 7.39 & 5.62 & 5.66 & 8.4 & 7.95 & 5.88 \\
\hline $\mathrm{InO}$ & 0.14 & 0.16 & 0.17 & 0.14 & 0.14 & 0.13 & 0.2 & 0.19 & 0.18 \\
\hline $\mathrm{IgO}$ & 12.20 & 8.62 & 6.03 & 6.12 & 5.06 & 4.13 & 8.6 & 10.38 & 6.31 \\
\hline $\mathrm{aO}$ & 9.75 & 11.58 & 8.18 & 7.72 & 7.79 & 7.48 & 9. & 8.53 & 9.22 \\
\hline $\mathrm{Ja}_{2} \mathrm{O}$ & 1.72 & 2.75 & 3.54 & 3.68 & 3.42 & 4.17 & 2.6 & 2.30 & 3.24 \\
\hline $\mathrm{K}_{2} \mathrm{O}$ & 1.22 & 1.70 & 1.38 & 1.38 & 2.06 & 2.22 & 0.7 & 1.53 & 1.72 \\
\hline $\mathrm{TiO}_{2}$ & 0.16 & 0.76 & 1.25 & 0.99 & 1.19 & 1.25 & 0.8 & 0.94 & 0.87 \\
\hline $\mathrm{P}_{2} \mathrm{O}_{5}$ & 0.10 & 0.22 & 0.24 & 0.16 & 0.72 & 0.78 & 0.3 & 0.58 & 0.38 \\
\hline \multirow[t]{2}{*}{$\mathrm{H}_{2} \mathrm{O}^{+}$. } & 1.94 & 2.30 & 2.10 & 2.17 & 2.56 & 1.86 & 0.6 & 2.08 & 1.66 \\
\hline & 99.31 & 99.54 & 99.53 & 99.66 & 99.88 & 99.46 & 99.3 & 99.21 & 99.57 \\
\hline
\end{tabular}

Niggli Basis

\begin{tabular}{ll|r|r|r|r|r|r|r|r|r}
\hline $\mathrm{Kp}$ & $\ldots$ & 4.5 & 6.0 & 5.0 & 5.1 & 7.5 & 8.1 & 2.4 & 5.7 & 6.3 \\
$\mathrm{Ne}$ & $\ldots$ & 9.3 & 15.0 & 19.5 & 20.1 & 18.9 & 22.8 & 14.1 & 12.9 & 18.0 \\
$\mathrm{Cal}$ & $\ldots$ & 18.3 & 12.0 & 15.6 & 15.5 & 13.2 & 11.7 & 20.9 & 9.0 & 13.8 \\
$\mathrm{Cs}$ & $\ldots$ & 5.6 & 11.1 & 4.2 & 3.8 & 4.0 & 4.2 & 2.4 & 7.3 & 6.3 \\
$\mathrm{Fs}$ III & $\ldots$ & 1.9 & 2.7 & 2.5 & 2.1 & 3.8 & 3.5 & 0.8 & 4.3 & 4.7 \\
$\mathrm{Fo}$ & $\ldots$ & 25.5 & 18.2 & 12.9 & 12.9 & 10.8 & 8.8 & 17.8 & 22.1 & 13.3 \\
$\mathrm{Fa}$ & $\ldots$ & 8.7 & 7.2 & 9.7 & 9.0 & 6.9 & 6.9 & 10.1 & 9.8 & 7.2 \\
$\mathrm{Ru}$ & $\ldots$ & 0.1 & 0.6 & 0.9 & 0.7 & 0.9 & 0.9 & 0.6 & 0.7 & 0.6 \\
$\mathrm{Cp}$ & $\ldots$ & - & 0.5 & 0.5 & 0.2 & 1.5 & 1.5 & 0.5 & 1.3 & 0.8 \\
$\mathrm{Q}$ & $\ldots$ & 26.1 & 26.7 & 29.2 & 30.6 & 32.5 & 31.6 & 30.4 & 26.9 & 29.0 \\
\hline
\end{tabular}

Niggli values

\begin{tabular}{ll|r|r|r|r|r|r|r|r|r}
\hline si & $\ldots$ & 100 & 113 & 122 & 129 & 140 & 144 & 115 & 113 & 123 \\
al & $\ldots$ & 19 & 18 & 24 & 25 & 25 & 26 & 24 & 14 & 23 \\
$\mathrm{fm}$ & $\ldots$ & 54 & 45 & 43 & 43 & 40 & 37 & 47 & 58 & 43 \\
$\mathrm{c}$ & $\ldots$ & 22 & 28 & 22 & 21 & 22.5 & 22 & 22 & 21 & 24 \\
alk & $\ldots$ & 5 & 9. & 11 & 11 & 12.5 & 15 & 7 & 7 & 10 \\
\hline
\end{tabular}

1. 33776 Hypersthene gabbro, eastern side of Niaqornap nunâ.

2. 33751 Metadolerite, western side of Lille Tugtutôq.

3. 54983 Pyroxene-bearing diorite with doleritic affinities, island west of Pârdlit.

4. 33797 Pyroxene-bearing diorite, small island WSW of Pârdlît.

5. 56647 Pyroxene-bearing diorite, northern side of Avatarmiut.

6. 33760 Pyroxene-bearing diorite, southern side of Avatermiut.

a. 51304 Hypersthene gabbro, Frederiksdal.

b. 55189 Noritic gabbro, Nordgletscher (Walton, 1965).

c. 55166 Augite-hornblende diorite, Valhaltinde (WaLton, 1965).

Analyst - B. I. Borgen. 
Table 3 (continued).

\begin{tabular}{c|c|c|c|c|c|c|c|c|c}
\hline No. & 1 & 2 & 3 & 4 & 5 & 6 & $a$ & $b$ & $c$ \\
GGU No. & 33776 & 33751 & 54983 & 33797 & 56647 & 33760 & 51304 & 55189 & 55166 \\
\hline
\end{tabular}

Niggli standard katanorm (Ilmenite variant)

\begin{tabular}{|c|c|c|c|c|c|c|c|c|c|c|}
\hline & $\mathrm{Q}$ & - & - & - & - & 2.3 & - & - & - & - \\
\hline & Or $\ldots$ & 7.5 & 10.0 & 8.3 & 8.5 & 12.5 & 13.5 & 4.0 & 9.5 & 10.5 \\
\hline & $\mathrm{Ab} \ldots$ & 15.4 & 22.5 & 32.5 & 33.5 & 31.5 & 38.5 & 23.5 & 21.5 & 30.0 \\
\hline & An .. & 30.5 & 20.0 & 26.0 & 25.8 & 22.0 & 19.5 & 34.9 & 15.0 & 23.0 \\
\hline & $\mathrm{Ne} \ldots$ & $\ldots$ & 1.5 & 一 & - & - & - & - & - & - \\
\hline & (Wo .. & 7.4 & 14.8 & 5.6 & 5.1 & 5.3 & 5.6 & 3.2 & 9.7 & 8.4 \\
\hline \multirow[t]{2}{*}{$\mathrm{Di}$} & En . . & 5.7 & 11.7 & 3.6 & 3.3 & 4.0 & 3.9 & 2.1 & 7.5 & 6.5 \\
\hline & $\mathrm{Fs}^{11} \ldots$ & 1.7 & 3.1 & 2.0 & 1.8 & 1.3 & 1.7 & 1.1 & 2.2 & 1.9 \\
\hline \multirow{2}{*}{$\mathrm{Hy}$} & $\int \mathrm{En}$. & 6.4 & - & 3.6 & 6.0 & 10.4 & 7.7 & 12.0 & 19.1 & 6.5 \\
\hline & $F_{s}{ }^{\prime \prime} \ldots$ & 2.0 & - & 2.0 & 3.2 & 3.6 & 3.1 & 6.0 & 5.7 & 1.9 \\
\hline \multirow{6}{*}{$\mathrm{Ol}$} & $F_{0} \ldots$ & 16.4 & 9.4 & 7.5 & 5.9 & - & 0.1 & 7.2 & 2.2 & 3.5 \\
\hline & $\mathrm{Fa} \ldots$ & 4.9 & 2.6 & 4.1 & 3.2 & - & 0.1 & 3.5 & 0.6 & 1.1 \\
\hline & Mt . . & 1.9 & 2.7 & 2.5 & 2.1 & 3.8 & 3.5 & 0.8 & 4.3 & 4.7 \\
\hline & Il & 0.2 & 1.2 & 0.9 & 1.4 & 1.8 & 1.8 & 1.2 & 1.4 & 1.2 \\
\hline & \multirow[t]{2}{*}{$\mathrm{Cp}$} & - & 0.5 & 0.5 & 0.2 & 1.5 & 1.5 & 0.5 & 1.3 & 0.8 \\
\hline & & 100.0 & 100.0 & 100.0 & 100.0 & 100.0 & 100.0 & 100.0 & 100.0 & 100.0 \\
\hline & $\mathbf{k}$ & 0.33 & 0.29 & 0.20 & 0.20 & 0.28 & 0.26 & 0.15 & 0.31 & 0.26 \\
\hline & $\mathrm{mg}$. & 0.71 & 0.65 & 0.51 & 0.54 & 0.50 & 0.46 & 0.62 & 0.61 & 0.53 \\
\hline & w $\ldots$ & 0.18 & 0.27 & 0.20 & 0.19 & 0.36 & 0.34 & 0.07 & 0.30 & 0.39 \\
\hline & $\mathrm{Q}$ & 26.1 & 26.7 & 29.2 & 30.6 & 32.5 & 31.6 & 30.4 & 26.9 & 29.0 \\
\hline & $\mathrm{L}$ & 32.1 & 33.0 & 40.1 & 40.7 & 39.6 & 42.6 & 37.4 & 27.6 & 38.1 \\
\hline & M & 41.8 & 40.3 & 30.7 & 28.7 & 27.9 & 25.8 & 32.2 & 45.5 & 32.9 \\
\hline & $\alpha$ & 0.34 & 0.35 & 0.24 & 0.36 & 0.66 & 0.37 & 0.51 & 0.56 & 0.33 \\
\hline & $\lambda$ & 1.54 & 1.64 & 2.61 & 2.84 & 2.84 & 3.30 & 2.32 & 1.21 & 2.32 \\
\hline & $\beta$ & 0.22 & 0.21 & 0.09 & 0.13 & 0.23 & 0.11 & 0.22 & 0.46 & 0.14 \\
\hline & $\pi$ & 0. & & 39 & 0.38 & 0.33 & 0.27 & 0.56 & 0.33 & 0.36 \\
\hline & $\gamma$ & 0.13 & 0.28 & 0.14 & 0.14 & 0.16 & 0.18 & 0.08 & 0.17 & 0.20 \\
\hline & $\mu$ & 0.61 & 0.46 & 0.44 & 0.46 & 0.42 & 0.38 & 0.57 & 0.51 & 0.42 \\
\hline
\end{tabular}

Modes (volume \%)

\begin{tabular}{|c|c|c|c|c|c|c|}
\hline Plagiocl. & 43.9 & 36.1 & 49.0 & 53.5 & 54.2 & 54.2 \\
\hline Hornbl. & 26.8 & 40.9 & 33.1 & 24.8 & 15.6 & 20.2 \\
\hline Biotite & 3.3 & 7.2 & 12.0 & 10.8 & 15.7 & 13.8 \\
\hline Gl. pyr. & 9.0 & 14.6 & 2.1 & 7.9 & 5.2 & 2.3 \\
\hline Hypersth. & 9.9 & - & - & - & - & - \\
\hline Olivine & 4.7 & - & - & - & - & - \\
\hline Quartz & - & - & - & 一 & 5.7 & 2.5 \\
\hline Microcl. & - & 一 & - & - & - & 2.2 \\
\hline Ore & 2.2 & 0.3 & 3.6 & 2.8 & 2.0 & 2.9 \\
\hline Access. & 0.2 & 0.9 & 0.2 & 0.2 & 1.6 & 1.9 \\
\hline
\end{tabular}




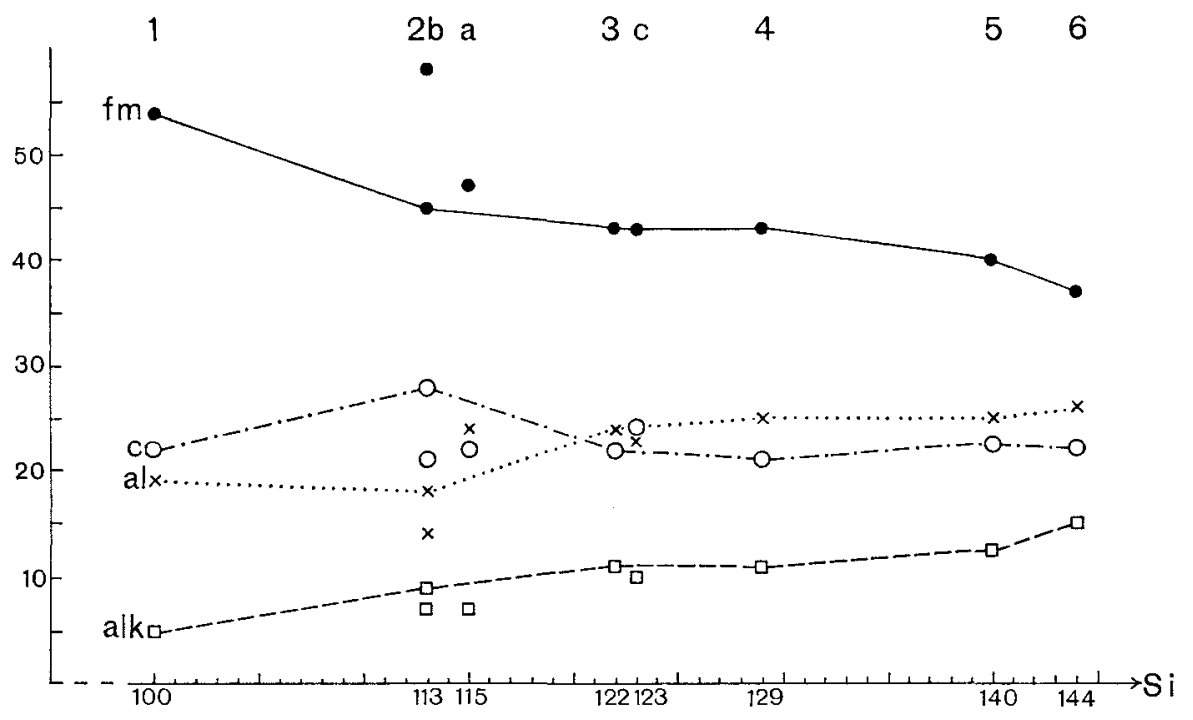

Fig. 21. Si-variation diagram of some basic and intermediate intrusives.

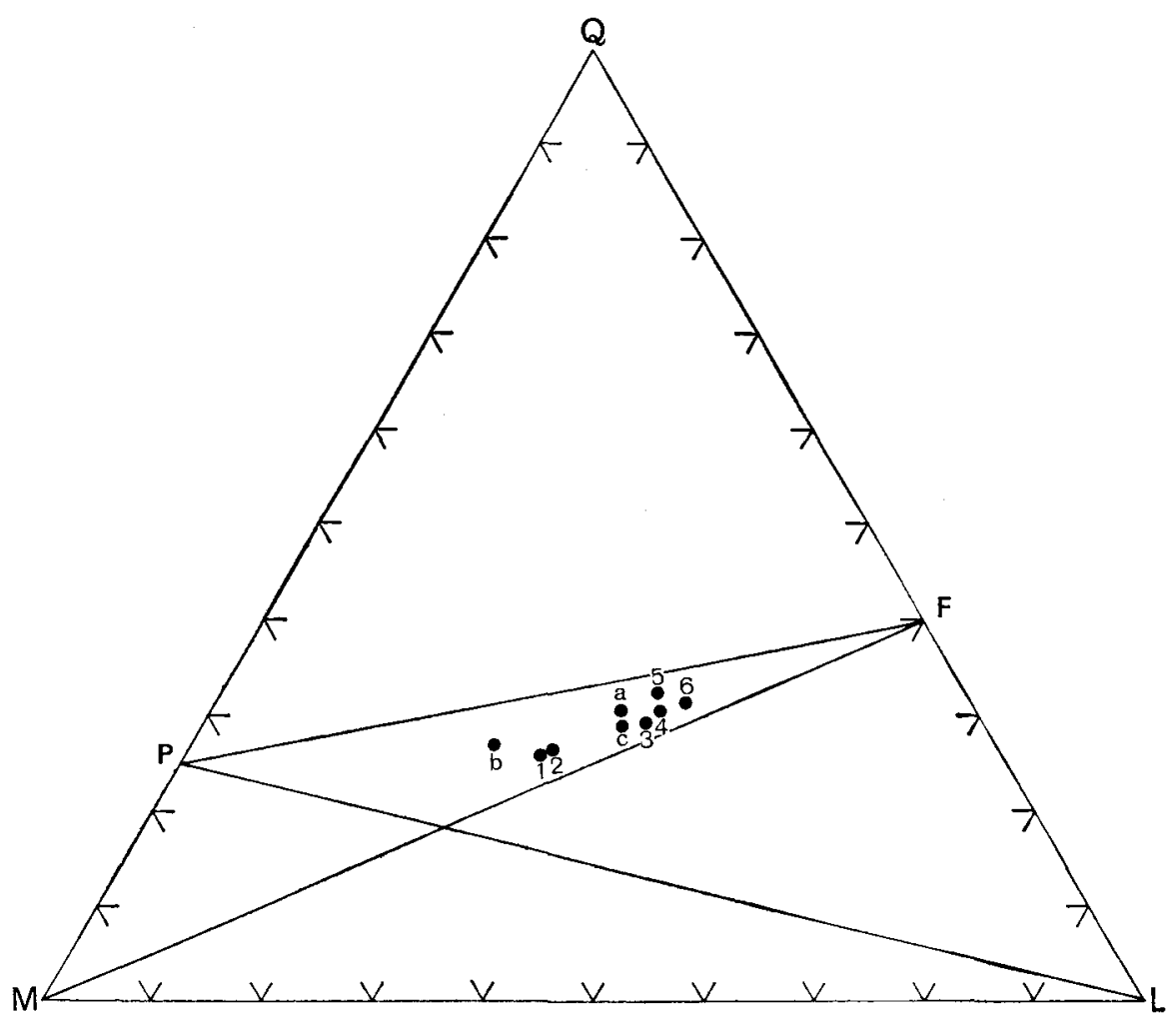

Fig. 22. QLM diagram of some basic and intermediate intrusives. 


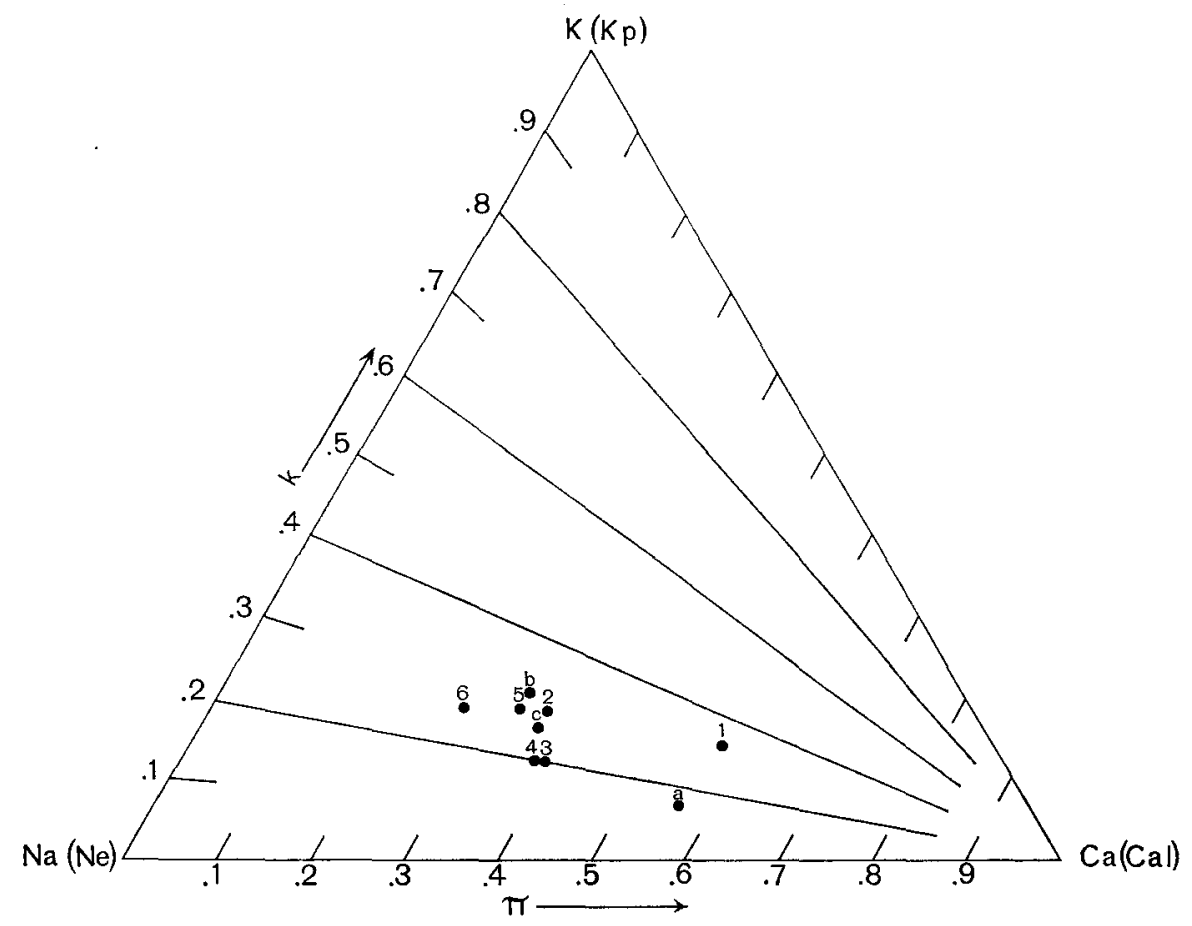

Fig. 23. KNaCa diagram of some basic and intermediate intrusives.

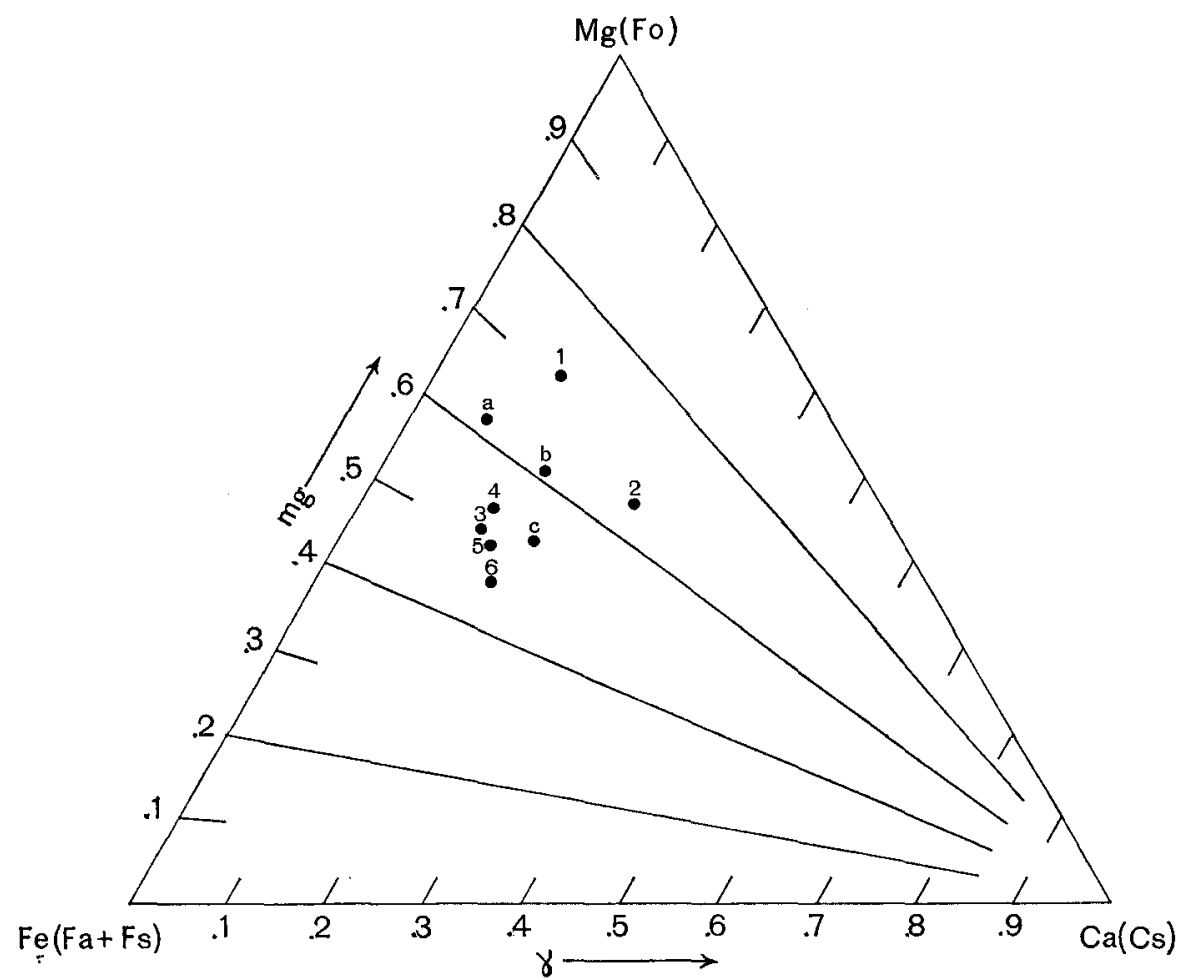

Fig. 24. MgFeCa diagram of some basic and intermediate intrusives. 
discrepancies between the plot in the diagram and the norm is the degree of oxidation. The higher this ratio, the more magnetite can be formed leaving more $\mathrm{SiO}_{2}$ for the production of pyroxene and eventually quartz.

The KNaCa plot (fig. 23) shows that the An content of normative plagioclase varies between 30 and $40 \%$ except in the two hypersthene gabbros where it is close to $60 \%$. The $\mathrm{Na}-\mathrm{K}$ ratio is fairly constant.

In the $\mathrm{MgFeCa}$ diagram (fig. 24) it can be seen that the mg ratio varies considerably. The $\gamma$ ratio (Ca bound to diopside) does not vary strongly, except that of the metadolerite of Bredef jord which is relatively high; this is due to the low $\mathrm{Al}_{2} \mathrm{O}_{3}$ content of the metadolerite.

With the available data the only preliminary conclusion warranted is that the members of the magmatic suite under consideration belong to the calc-alkaline series. This supports the proposal put forward by Walton (1965, p. 61) for similar rocks north of Narssarssuaq. 


\section{OLDER BASIC INTRUSIVES}

\section{Possibilities of recognition of pre- or early orogenic dykes}

In general there is only a small chance that pre- or early orogenic basic intrusives can be recognised in granitic and metamorphic terrain. They are best preserved in the metamorphosed supracrustals. This is especially the case when the competency differences between the sills and dykes on the one hand and the surrounding earlier sediments and volcanics on the other hand are relatively small. When these differences are relatively great the slight discordance of the sills will easily be effaced by later deformation, so that their distinction from isolated lava horizons and even from metamorphosed calcareous rocks is largely impossible in the field. The chance that intrusive structures of pre- or early orogenic dykes and sills can still be recognised in granitic and gneissic rocks derived from original sediments is even smaller, when it is remembered that, besides deformation, feldspathisation and granitisation have been active.

Paradoxically, it is in the granitic and gneissic relicts of the old preorogenic basement that such early dykes may be easiest to recognise. Although such a basement may have been reworked and reconstituted, no new material has normally been added. Therefore there is a greater chance that, at least locally in the basement relicts, older planar elements and structures, although probably changed in direction by later deformation, will be preserved. Such elements are the means by which the intrusive relationships of the pre- or early orogenic dyke relicts may be demonstrated (see in this respect also RAMSAY, 1963, fig. 15, 16; WATSON, 1965, fig. 2.3.).

\section{The double-folded composite basic body along Bredefjord}

On the south-eastern side of Bredef jord there is an intersection between a non-folded metadolerite dyke and a double-folded body of basic to intermediate composition (plate 1). The latter is composite consisting of two components of the same width. One is made up of 
homogeneous, dark grey basic amphibolite, composed of a fine-grained ground mass in which there is a large number of hornblende aggregates. The other component is light grey and composed of a fine-grained granoblastic aggregate of acid plagioclase and biotite. The rocks are homogeneous and show no traces of banding. The two components are locally separated by septa of country rock. In one place the leucocratic component veins the basic component and contains a few inclusions of it.

There are two sets of folds. The first are open folds with axes trending NW, while the second are isoclinal folds with vertical axial planes and axes trending NE to NNE, as can be seen in plate 1. The metadolerite dyke which cuts the composite body is not folded, proving that it is later than the NW folding. In the present locality there is no conclusive proof that this dyke is younger than the $\mathrm{NE}$ folding, as its trend is parallel to the axial planes of the NE folds. However, nearby there are other metadolerite dykes belonging to the same swarm and these are folded about NE axes (see p. 103 and fig. 39). The axial planes of these folds dip shallowly to the NW and thus have a different attitude to the axial planes of the isoclinal folds of the composite zone. Moreover, the folds in these nearby metadolerite dykes are open and thus contrast with the isoclinal folds of the composite body. These features suggest that there were two phases of deformation of different ages in the area both producing folds with $\mathrm{NE}$ axes. The oldest is earlier and the youngest later than the metadolerites.

The country rock is a porphyritic hornblende-biotite granodiorite which displays no foliation in this locality. There is however a concentration of several basic inclusions oriented in a NNE-SSW direction. One of the inclusions appears to stop at the contact of the composite body (see fig. 25 and plate 1).

The relations of the composite body to the basic inclusions in the country rock granodiorite give rise to the following considerations. Although repeatedly folded before the emplacement of the metadolerites, this body has been very well preserved. Towards the east it can be followed for several tens of metres. Lichen and overgrowth do not however enable its continuation to be traced farther inland. In contrast the basic rock from which the basic inclusions were derived was almost completely replaced and digested. It is inconceivable that the metamorphism and the folding of the composite body belong to the same episode of plutonism as the granitisation of the inclusions; such extreme selective replacement amongst rocks of similar composition is difficult to imagine. Moreover, the composite body is clearly discordant to the inclusions and such relations are amongst the criteria, although not completely conclusive, listed by Watterson (1965, p. 123) for distin- 


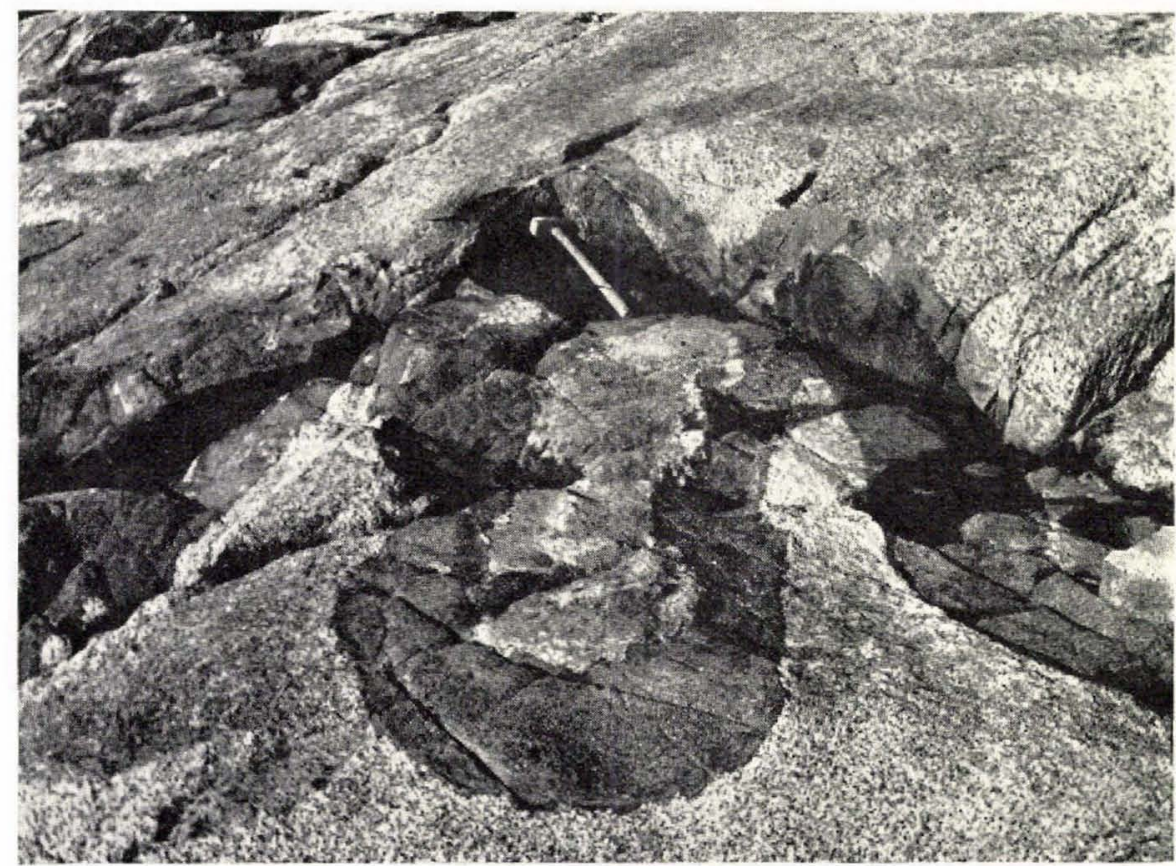

Fig. 25. Close-up of NE-trending folds in a composite, possible preorogenic dyke relict (plate 1). Above the right hand fold there is a basic inclusion in the granite which stops at the contact of the composite dyke relict. Lille Tugtutôq, south-eastern side of Bredef jord.

guishing so-called post-granitic relict dykes emplaced into granitic country rock which subsequently was reactivated, from dykes emplaced into non-granitic country rocks which were subsequently granitised. It is therefore concluded that the country rock granodiorite here underwent its main granitisation during an episode of plutonism which preceded the emplacement of the composite body and the two phases of folding which affected it. This might imply that the granodiorite which constitutes a thick band in the nebulitic series (variety 1) represents a granitic element of pre-Ketilidian basement into which the composite body was intruded. The supposition that the granitisation which produced this granite band is very early 1 st episode in age is improbable, as this would mean that the plutonic evolution during the 1st episode has been interrupted by the intrusion of the composite body. Until now nowhere in the Ketilidian mobile belt has evidence been found in support of a break during the 1st episode marked by basic dyke intrusion. The full implications of the interpretation presented are discussed on p. 119. 


\section{Double-folded discordant amphibolites in metamorphosed supracrustals on Mato island}

On Mato island at the south-west point of Julianehåb peninsula amphibolitic supracrustal rocks have been recorded by NesBitт (1961). These are well banded and clearly double-folded. The first phase of deformation is defined by an $\mathrm{S}_{1}$ (mineral orientation) which is parallel

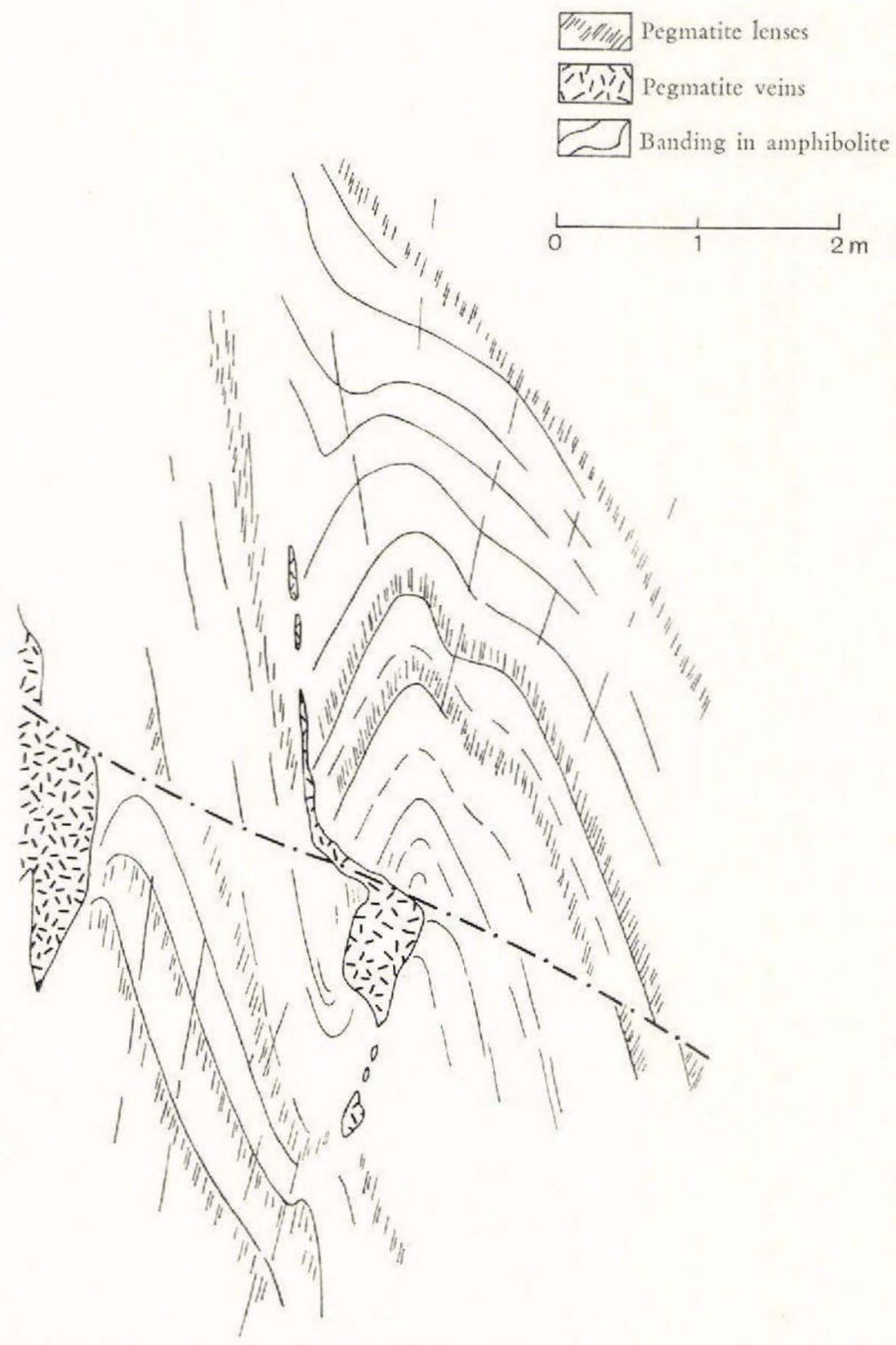

Fig. 26. $\mathrm{F}_{2}$ folds (plunging $20^{\circ} \mathrm{SW}$ ) in metamorphosed supracrustals. Plane of drawing $165 / 50 \mathrm{NW}$ seen towards the SSW. Mato island. 
to the bedding in the rock series and an $\mathrm{L}_{1}$ marked by the elongation of hornblende prisms and usually with a very steep attitude. $F_{1}$ folds are only visible in small-folded pegmatite veins the folds of which are isoclinal and their axial planes parallel to $\mathrm{S}_{1}$. The second phase is defined by open symmetrical folds with axes trending $\mathrm{NE}$ and by an $\mathrm{S}_{2}$ which is marked by a concentration in some layers of thin pegmatite lenses, $10 \mathrm{~cm}$ in length (see fig. 26). These lenses are almost parallel to the axial planes of the $F_{2}$ folds and show a fan-like arrangement. Only in those layers containing the pegmatitic lenses has the $L_{1}$ not been preserved. In one place the $L_{1}$ bends around an $F_{2}$ fold hinge.

In a few places there are 0.5-1 $\mathrm{m}$ wide discordant amphibolite bodies, with parallel margins, which transect the banding in the supracrustals. These bodies are folded and crosscut by the $S_{1}$; in the bodies there is a lineation parallel to the $\mathrm{L}_{1}$ in the supracrustals. This is strong evidence that the discordant amphibolites predate the first phase of deformation. The crosscutting relations of the bodies to the banding demonstrate that they represent original basic dykes. The following succession can thus be set up:

$\begin{array}{ll} & \text { NE folding }\left(\mathrm{F}_{2}\right)-\text { pegmatisation } \\ & \text { NW folding }\left(\mathrm{F}_{1}\right) \text { - metamorphism } \\ & \text { pegmatisation } \\ \text { basic dykes (preorogenic?) } & \text { volcanic rocks }\end{array}$

\section{The metagabbro of Torssukátak fjord}

In the nebulitic series along the north-western side of the body of allochthonous granite belonging to variety 4, there is a body of metagabbro, $500 \mathrm{~m}$ long and $70 \mathrm{~m}$ broad. As far as can be seen on a steep slope, its attitude is practically vertical and it trends 080 . The foliation in the surrounding rocks trends 060 and dips moderately to steeply to the north-west; the metagabbro is therefore slightly discordant (see diagram in fig. 27). It has to be noted however that immediately against the metagabbro the foliation in the country rocks is parallel to the contacts of the body.

In its central part the metagabbro is very coarse-grained, and it consists mainly of hornblende and plagioclase and a small amount of biotite. In the least deformed parts of the body the hornblende forms stumpy crystals, a rather uncommon habit for this mineral. These reach up to $5 \mathrm{~cm}$ and are sieved with equidimensional and slightly elongate plagioclase crystals averaging $5 \mathrm{~mm}$ in size. Deformation has usually changed the primary texture of the rock producing a foliation which is 


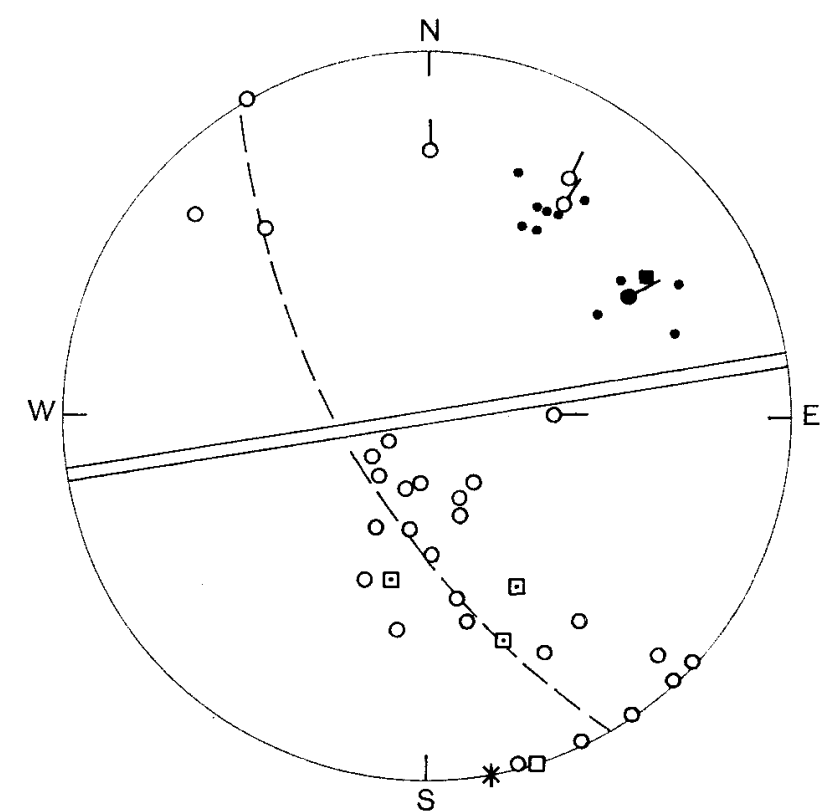

$\square$ Poles of layering in metagabbro

$\checkmark$ Poles of foliation in metagabbro

o Poles of foliation in metagabbro host rock

- Lincations within metagabbro body

- Lineations in metagabbro host rock

$\rho$ Fold axes $\left\{\begin{array}{l}\text { Constructed } \\ \text { Measured }\end{array}\right.$
$*$ Pole of metagabbro body

Fig. 27. Stereogram of structural elements from a metagabbro and its host rock plotted on the lower hemisphere of an equal area projection. North-east side of Torssukátak fjord.

defined by the orientation of fragmented and elongated plagioclase crystals and of biotite flakes. Along the northern contact of the body there is a $2-3 \mathrm{~m}$ wide zone of fine- to medium-grained metagabbro. The change in grain size towards the centre is very gradual. Along the southern side such a marginal zone is masked by strong veining by the country rock granite.

Thin zones of fine- to medium-grained amphibolite extend from the gabbro into the surrounding rocks. These zones are concordant to the gneiss structures. They can be traced for at least several tens of metres and are obviously apophyses of the metagabbro itself. The rock in these zones is identical in texture and grain size to that in the marginal facies of the gabbro body which suggests that the small grain size of these rocks is an original feature produced by chilling and is not the result of subsequent recrystallisation. 


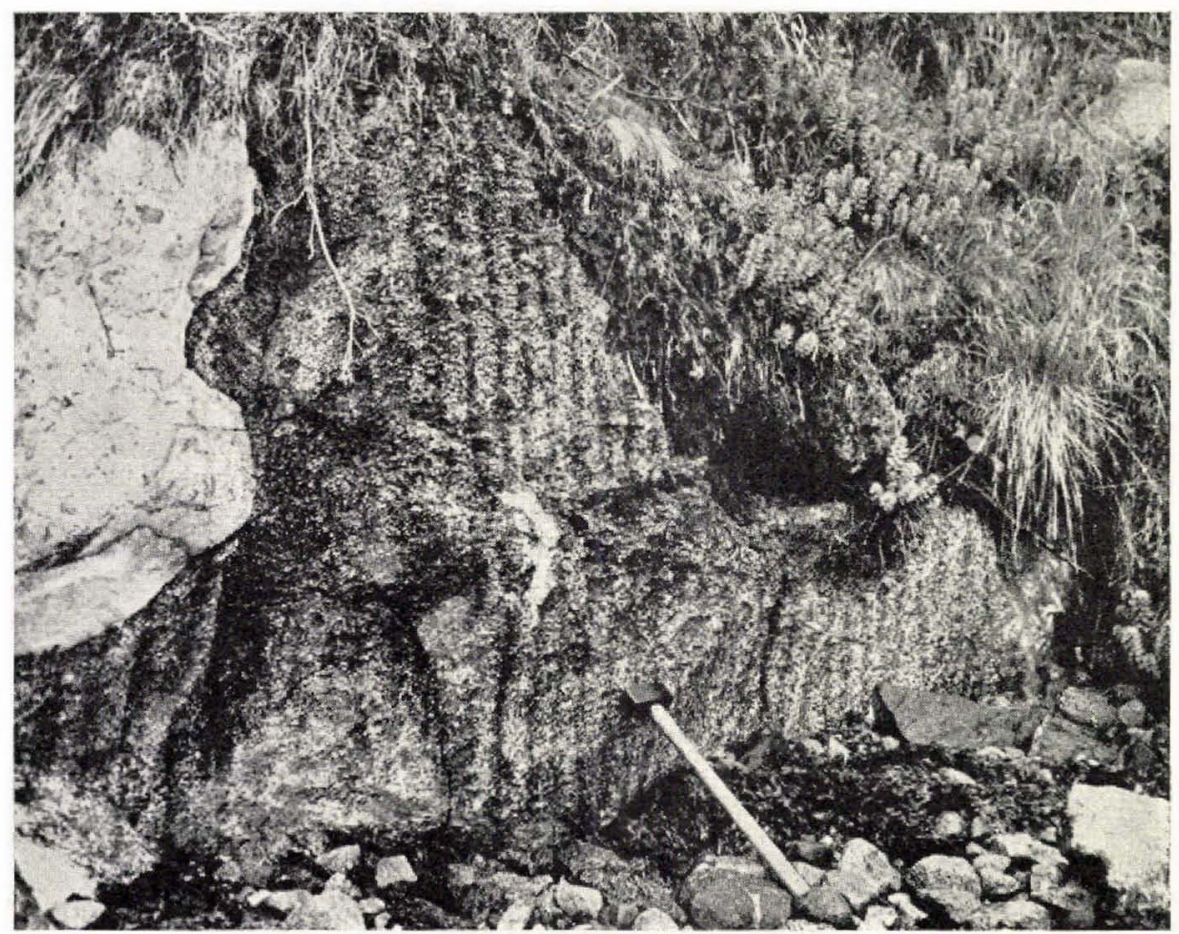

Fig. 28. Vertical igneous layering in metagabbro. North-eastern side of Torssukátak f jord.

In one place in the metagabbro, $10 \mathrm{~m}$ from its northern margin, banding is displayed in which mafic bands, $2-3 \mathrm{~cm}$ thick, alternate with others richer in plagioclase (fig. 28); no grading has been observed. The banding is parallel to the contact of the body (see fig. 27). The fact that the banded rock is coarse-grained is thought to be incompatible with an origin by deformation; in addition the foliation which is clearly the result of deformation crosscuts the earlier banding. Along the northern margin of the body the foliation is parallel to the contact but farther towards the centre it is clearly oblique and more or less parallel to the regional foliation in the country rocks (see fig. 27). After the formation of the foliation two generations of leucocratic veins (aplitic and pegmatitic) were emplaced and these were followed by a second phase of folding which folded the foliation and the veins about axes plunging ENE. Along the northern contact the country rock granite veins the marginal facies of the metagabbro for a distance of $0.5 \mathrm{~m}$. This veining was connected with or controlled by deformation by means of which the basic rock was fragmented into lenses with their long axes lying parallel to the foliation and the contact. 
Petrography. Hornblende occurs as large crystals which are very rich in ore inclusions forming very thin flakes arranged parallel to the cleavage of the crystals. Along their margins the hornblende crystals are free of ore. Ore is also concentrated in thin seams cutting the cleavage which are reminiscent of the irregular fractures often developed in pyroxene. These features and the habit of the hornblende crystals might suggest that at least part of the hornblende has originated at the expense of pyroxene. Relicts of pyroxene have however not been found. Some of the large hornblende crystals have been partly to completely recrystallised to form aggregates in which the smaller grains are completely free of ore inclusions.

Plagioclase occurs as large subhedral crystals or as elongated aggregates. Some of the larger crystals clearly show incipient stages of breaking down into fine-grained aggregates. Most of the plagioclase is strongly clouded by saussuritic material. Brown pleochroic biotite mainly forms trails of oriented flakes. These trails usually have an undulatory course, which is locally so pronounced that it forms microfolds. This is in accordance with observations in the field where at least locally the foliation was seen to be folded about ENE-plunging axes.

Accessories are ore and apatite; the latter forms large prismatic crystals. 


\section{CHRONOLOGY AND CORRELATION}

\section{The procedure followed to build up the chronology}

At the north-west side and in the region to the south-east of the Julianehåb district Ketilidian supracrustals or preorogenic dykes have been used as a starting point to build up the chronology. However, there are no continuous marker horizons which can be followed from the adjacent regions through the Julianehåb district. Therefore the possibility cannot be excluded that smaller or larger parts of the Julianehåb granite originated at the expense of pre-Ketilidian basement and not from Ketilidian sediments. Consequently correlation of relict dykes within the Julianehåb granite will always remain uncertain unless other time markers are found which allow for reliable large scale correlations. Fortunately there are good time markers, i.e. swarms of tholeiitic dykes which can be followed from the Julianehåb district towards the Unartoq Fjord more to the south-east, where the chronology of the Ketilidian events is well established. These dykes postdate all of the plutonic events in the crust of South Greenland, but they were intruded before the earliest dolerite dykes of the Gardar period.

The fact that these time markers are amongst the youngest rocks in the area has made it necessary to follow a different procedure from that used by the workers in the surrounding regions and to build up the chronology in reversed order. This means that in each locality visited first the youngest and then successively older basic and intermediate intrusions had to be recognised, and their relations to intervening plutonic events had to be established. A great number of local chronologies from localities evenly distributed throughout a sufficiently large area enabled the establishment of a regional chronology which can be used as a basis for correlation with the adjacent regions in South Greenland. This procedure is also the reason why in this paper the basic and intermediate intrusives are described in reversed chronological order.

The area investigated has been divided into 5 subareas. The chronology established in each of the subareas will successively be dealt with, starting with Julianehåb peninsula and proceeding westwards. At the same time the nature of the evidence which forms the basis of the chronology will be outlined. 
TABLE 4

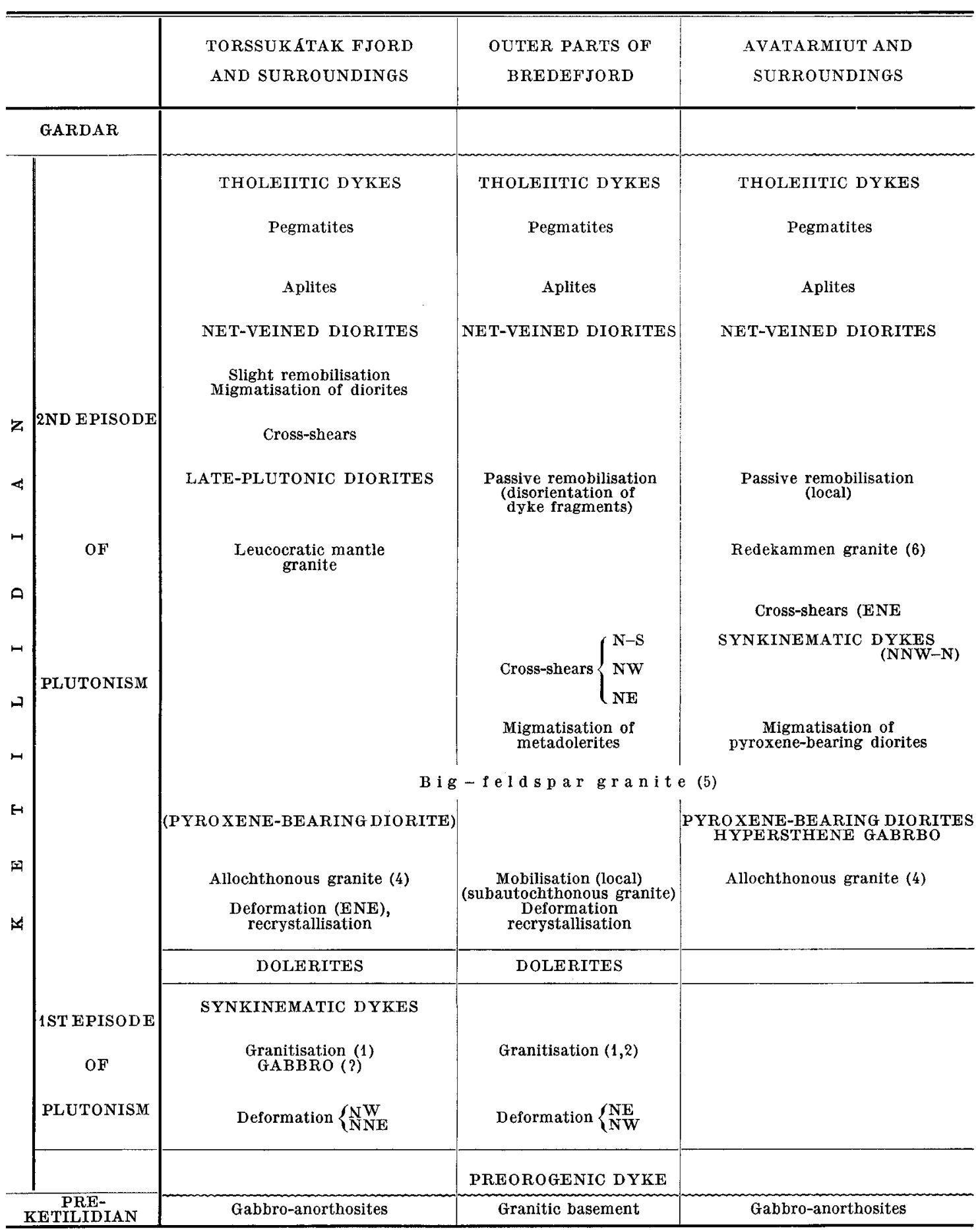


TABLE 4 (continued)

\begin{tabular}{|c|c|}
\hline $\begin{array}{l}\text { PÂRDLÂT AND } \\
\text { SURROUNDINGS }\end{array}$ & $\begin{array}{cc} & \text { J U L I A N E H \& B P E N I N S U L A } \\
\text { SW SIDE } & \text { SE SIDE }\end{array}$ \\
\hline & - \\
\hline THOLEIITIC DYKES & THOLEIITIC DYKES \\
\hline Pegmatites & $\begin{array}{llllllllllll}P & \text { e } & \mathbf{g} & \mathbf{m} & \mathbf{a} & \mathbf{t} & \mathbf{i} & \mathrm{t} & \mathrm{e} & \mathrm{s} & \begin{array}{l}\text { (final consolidation stages } \\
\text { in Redekammen granite: Arpatsivik) }\end{array}\end{array}$ \\
\hline Aplites & $\begin{array}{lllllll}\text { A } & \mathbf{p} & \mathbf{l} & \mathbf{i} & \mathrm{t} & \mathrm{e} & \mathrm{s}\end{array}$ \\
\hline NET-VEINED DIORITES & NET-VEINED D IOR I TES \\
\hline \multicolumn{2}{|l|}{$\begin{array}{l}\text { Passive remobilisation } \\
\text { (disorientation of } \\
\text { dyke fragments) }\end{array}$} \\
\hline Cross-shears (ENE) & $\begin{aligned} \text { Re d e k a m e n t y p e gra } \mathrm{n} \text { i e (6) } \\
\\
\text { Granodioritic dykes } \\
\text { Green dykes (E-W,ENE) }\end{aligned}$ \\
\hline SYNKINEMATIC DYKE (N-S) & $\begin{array}{r}\text { G r e y d y k e s ( N N W- N) } \\
\text { Green dykes (NW-NNW) }\end{array}$ \\
\hline $\begin{array}{l}\text { Migmatisation of } \\
\text { pyroxene-bearing diorites }\end{array}$ & $\begin{array}{l}\text { G } r \text { e } y \text { d y } k \text { e } s(N E-N N E) \\
\text { Migmatisation } \\
\text { of hornblendite }\end{array}$ \\
\hline PYROXENE-BEARING DIORITES & HORNBLENDITE \\
\hline Allochthonous granite (4) & Allochthonous granite (4) \\
\hline $\begin{array}{c}\text { Deformation, } \\
\text { recrystallisation }\end{array}$ & $\begin{array}{l}\text { Deformation, } \\
\text { recrystallisation, } \\
\text { pegmatisation }\end{array}$ \\
\hline DOLERITES & HYPERSTHENE GABBRO \\
\hline $\begin{array}{l}\text { Granitisation } \\
\quad \text { (marginal facies of JuI }\end{array}$ & $\begin{array}{l}\text { Granitisation } \\
\text { ehåb-Igaliko body) }\end{array}$ \\
\hline Deformation & Deformation $\left\{\begin{array}{l}\mathrm{NW} \\
\mathrm{NE}\end{array}\right.$ \\
\hline $\begin{array}{l}\text { Supracrustals } \\
\text { (volcanic) }\end{array}$ & $\begin{array}{l}\text { Supracrustals with } \\
\text { PREOROGENIC DYKES }\end{array}$ \\
\hline
\end{tabular}




\section{The chronological relationships of the tholeiitic dykes and the latest leucocratic veins}

Throughout the area investigated the tholeiitic dykes crosscut late leucocratic veins and representatives of all the basic and intermediate intrusives described in the preceding sections. Nowhere are the dykes veined by the country rock granite. It is therefore clear that the crust was practically dead, though perhaps not yet completely cold, when the dykes were intruded. Evidence from the vicinity of Unartoq Fjord (Persoz, in press; D. Bridgwater, personal communication) indicates that the dykes predate the earliest Gardar dolerites and faults.

In the eastern part of the Julianehåb district and a little to the south-east generally flat-lying veins of pegmatite and aplite are widespread and these crosscut the intrusive bodies of net-veined diorite without change in direction.

In some places, e.g. on an island west of Pârdlit and on Avatarmiut there are thin, flat-lying pegmatite veins which show a different behaviour with respect to the net-veined diorites than the above leucocratic veins. When meeting a sheet of net-veined diorite these pegmatite veins do not crosscut the sheet, but they follow the contact plane of the sheet. After having followed the contact for some distance they are often seen to change their course and again to continue into the granite. Here and there such pegmatites occur at both sides of the sheets as is shown in fig. 1. The observations show that the pegmatite veins are dilational and also that they do not replace the diorite or the net-veins. The pegmatite veins are crosscut by the leucocratic veins mentioned in the preceding paragraph. It is suggested that the pegmatite veins were emplaced shortly after the intrusion of the diorites at a time when the latter were still at a higher temperature than the country rock such that the contact planes of the sheets constituted critical planes of discontinuity.

In the north-eastern part of Igaliko peninsula there is an aplite body, 100-200 $\mathrm{m}$ in size, which truncates basic inclusions and basic schlieren in the surrounding slightly porphyritic granodiorite (variety 4). Generally the aplite is remarkably homogeneous. Here and there along the margin of the body layering defined by very thin biotitic and thick feldspathic layers is displayed. In some places the layering can be seen to follow the irregularities of the contact. These features suggest that the body is intrusive. However, in one place a net-veined diorite proceeds from the surrounding granite into the aplite body and can be followed continuously for at least $80 \mathrm{~m}$. Within the body the diorite is veined by the aplite in a way which is identical to net-veining developed elsewhere in the net-veined diorites. At the place where the diorite sheet enters the aplite body, the aplite can be seen to replace the margins of the sheet 
and to form net-veins in its central part. The continuity of the diorite in the aplite body seems to conflict with the intrusive relations of the latter. It is therefore suggested that the aplite body and the diorite sheet were more or less contemporaneous. It seems thus that the aplite body was emplaced slightly earlier than the diorite sheet which was intruded before the aplite had solidified such that the aplite was still able to net-vein the diorite before the final stages of consolidation were completed.

The above features and the relations of the synkinematic dykes of Julianehåb peninsula (section V) to leucocratic veins show that leucocratic veining considerably overlapped the intrusion of the net-veined diorites and the synkinematic dykes.

With these relations established for the whole area investigated the treatment of the chronologies of each of the subareas can be started with the net-veined diorites.

\section{The chronology of Julianehåb peninsula}

The south-eastern part of the peninsula is made up of porphyritic biotite-hornblende granodiorite (variety 4), which is generally homogeneous. However in a $2-3 \mathrm{~km}$ wide marginal zone of non- or slightly porphyritic granodiorite, adjacent to the NE-trending gneiss band in the north-western part of the peninsula, there are numerous inclusions of gneiss, amphibolitic supracrustal rocks and fragments of metadolerite dykes.

Sheets of net-veined diorite are frequent in the south-eastern part of the peninsula. At nine localities they crosscut synkinematic dykes which include representatives of all generations of the succession given on p. 27 (see also table 4).

The net-veined diorites and the synkinematic dykes are separated by the emplacement of a large and a small body of Redekammen type granite (variety 6). On the island Arpatsivik immediately east of Julianehåb peninsula there are three parallel and continuous sheets of netveined diorite crosscutting the Redekammen type granite. These sheets occur in line with three sheets on the opposite side of the fjord on the eastern side of the peninsula where the host rock is the porphyritic granodiorite variety 4. On the island occasional veins, identical to the host granite, penetrate the diorite bodies and their aplite mantles. However on the peninsula it is clear that the host granite did not vein the sheets after their intrusion. These features indicate that the sheets were intruded after the emplacement of the leucocratic granite, but before the final stages of solidification came to an end. In the northern part of the peninsula, not far outside the westernmost contact of the Redekammen granite body, two synkinematic dykes belonging to the 
first and third generation of the succession given on p. 27 are veined by thick veins of that granite and at the contacts the dykes are truncated.

On a small peninsula at the southern side of Julianehåb peninsula there is another body of leucocratic granite which in one locality contains a great number of randomly oriented fragments of green and grey synkinematic dykes, while nearby a few flat-lying sheets of net-veined diorite crosscut the leucocratic granite without any sign of being attacked by it.

In the south-west side of Julianehåb peninsula there are swarms of NE-trending synkinematic dykes belonging to the first generation and single N-S to NNW-trending synkinematic dykes belonging to the third generation. None of these are attacked by the country rock granite, variety 4.

In fig. 29 the relations are shown between a synkinematic dyke (first generation of p. 27) and an older very elongate intrusive body of hornblendite which can be followed without interruption for at least $3 \mathrm{~km}$ landwards. The synkinematic dyke truncates a vein of country rock granite transecting the hornblendite body which over its whole length is migmatised by the country rock granite (variety 4). The synkinematic dyke continues in a NE direction for $50 \mathrm{~m}$ where it wedges out in a hot shear zone. The relations in this locality show that the oldest generation of synkinematic dykes is separated from the intrusion of the hornblendite body by a phase of plutonic activity during which the hornblendite was migmatised under quiet conditions in the absence of deformation.

In the marginal zone of the allochthonous granite adjacent to the gneiss zone mentioned above fragments of metadolerite are very frequent. These were torn apart for tens of metres or much more, as has been shown in section VIII, and their disrupted character contrasts strongly with the continuous course of the unmigmatised synkinematic dykes and of the hornblendite body in the neighbourhood. In one locality there is a N-S trending synkinematic dyke, a few hundred m long, only $20 \mathrm{~m}$ from the remains of what was once a metadoleritic dyke (see fig. 17). The contrasting appearance of the different groups of dykes is a consequence of mobilisation and extreme stretching in the host rock which predates the emplacement of the synkinematic dykes and that of the hornblendite body.

The presence of the numerous metadoleritic dyke fragments and inclusions of supracrustal rocks in the marginal zone mentioned above and the complete absence of these more to the south-east suggest that the granite of the Julianehåb peninsula is allochthonous. In the marginal zone the degree of mobilisation and homogenisation was apparently not strong enough to remove recognisable relicts of pre-existing rocks. This 


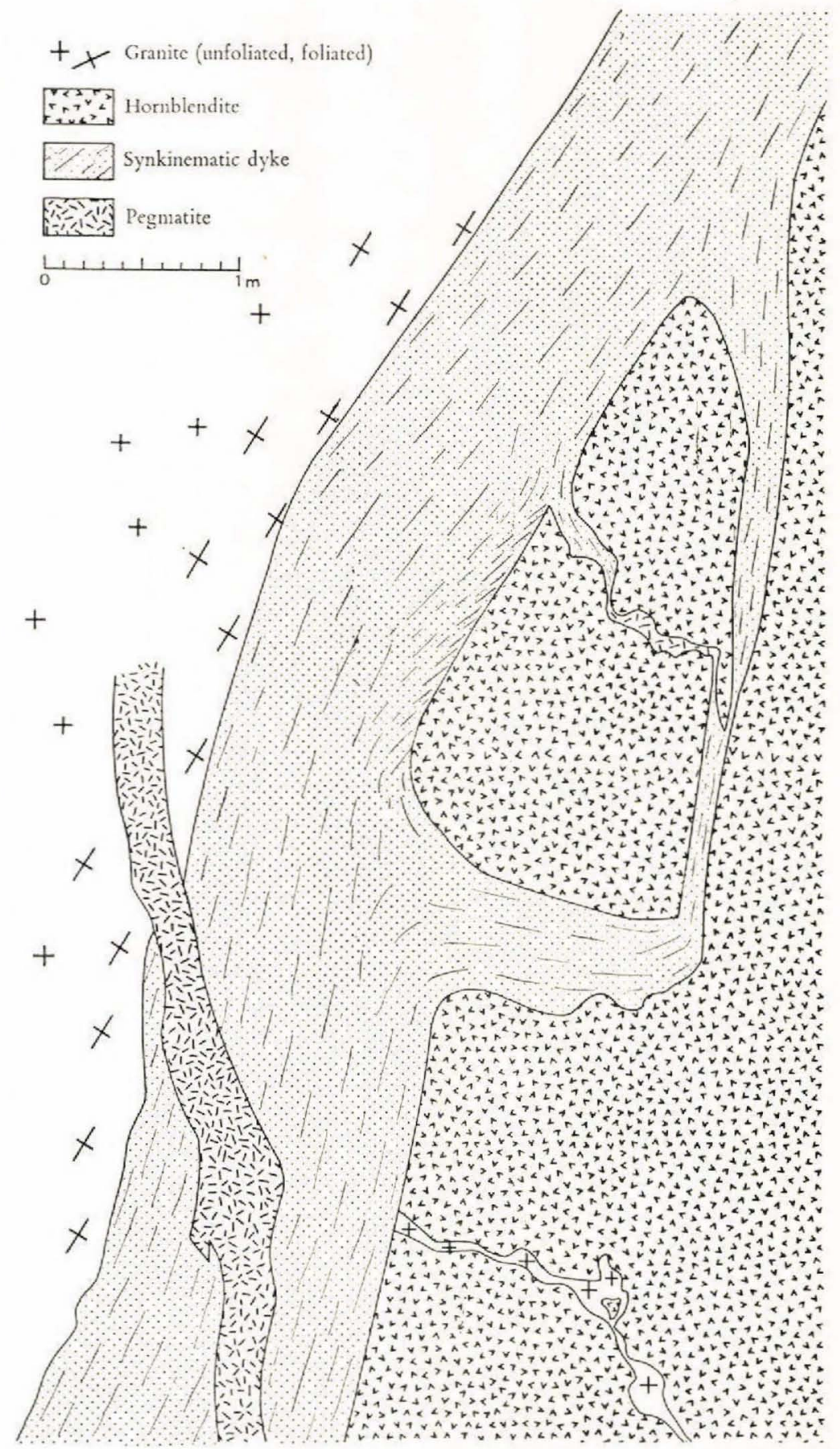

Fig. 29. Hornblendite body (similar in age to pyroxene-bearing diorites) penetrated by synkinematic dyke which truncates a vein of Julianehåb granite which transects the hornblendite. South-western side of Julianehåb peninsula. 
idea is supported by the fact that the granite in the central parts of the body is porphyritic while it is non- or slightly porphyritic in the marginal facies. The explanation presented is only valid if it can be shown to be probable, at least, that in the south-eastern part of the peninsula there were originally dolerites before the emplacement of the allochthonous granite. In the surrounding areas of gneiss and autochthonous granite, metadolerites of the same age as those in the marginal zone (see ahead), are frequent and very regular; thus the above condition can be considered as satisfied.

Summarising, the intrusion of the metadolerites was followed by the emplacement of a pluton of allochthonous granite in the marginal facies of which, after its solidification, a hornblenditic intrusive body was intruded. Subsequently, during a phase of quiet remobilisation, this body was migmatised in the absence of deformation and movement in the granite. Still later, return to brittle conditions in the granite permitted the intrusion of several generations of synkinematic dykes mainly concentrated in the central part of the body. These were followed by the emplacement of two bodies of leucocratic granite of Redekammen type and finally numerous sheets of net-veined diorite were intruded.

It is admitted that the establishment of the two earliest phases of granite development is incomplete. More conclusive evidence from the islands immediately to the south-west of the peninsula is presented in the following subsection. In addition a third phase of mobilisation which postdates the two earlier phases will be demonstrated.

\section{The chronology of Pârdlît island and surroundings}

On Pârdlît, a well exposed island immediately to the south-west of Julianehåb peninsula, several basic and intermediate dykes have been mapped (see detailed map in fig. 30). Most of the island is made up of a slightly porphyritic hornblende-biotite granodiorite which is the continuation of the marginal facies of the allochthonous granite (variety 4) of Julianehåb peninsula. To the south-east of the central bay which almost divides the island in two halves a weak foliation, marked by the orientation of inclusions and/or a crude orientation of the mafics, trends ENE and has a vertical attitude; in the western half it is gently dipping. At the north-west side of the bay there is a flat-lying shear belt of lineated granite which is practically parallel to the earlier foliation (see below) in the overlying granite. The upper part of the belt does not come higher than $5 \mathrm{~m}$ above sea level.

In the middle of the island there is a continuous grey synkinematic dyke with an average N-S trend, found on both sides of the central bay. The dyke has a well developed sigmoidal foliation and it lies in line with 


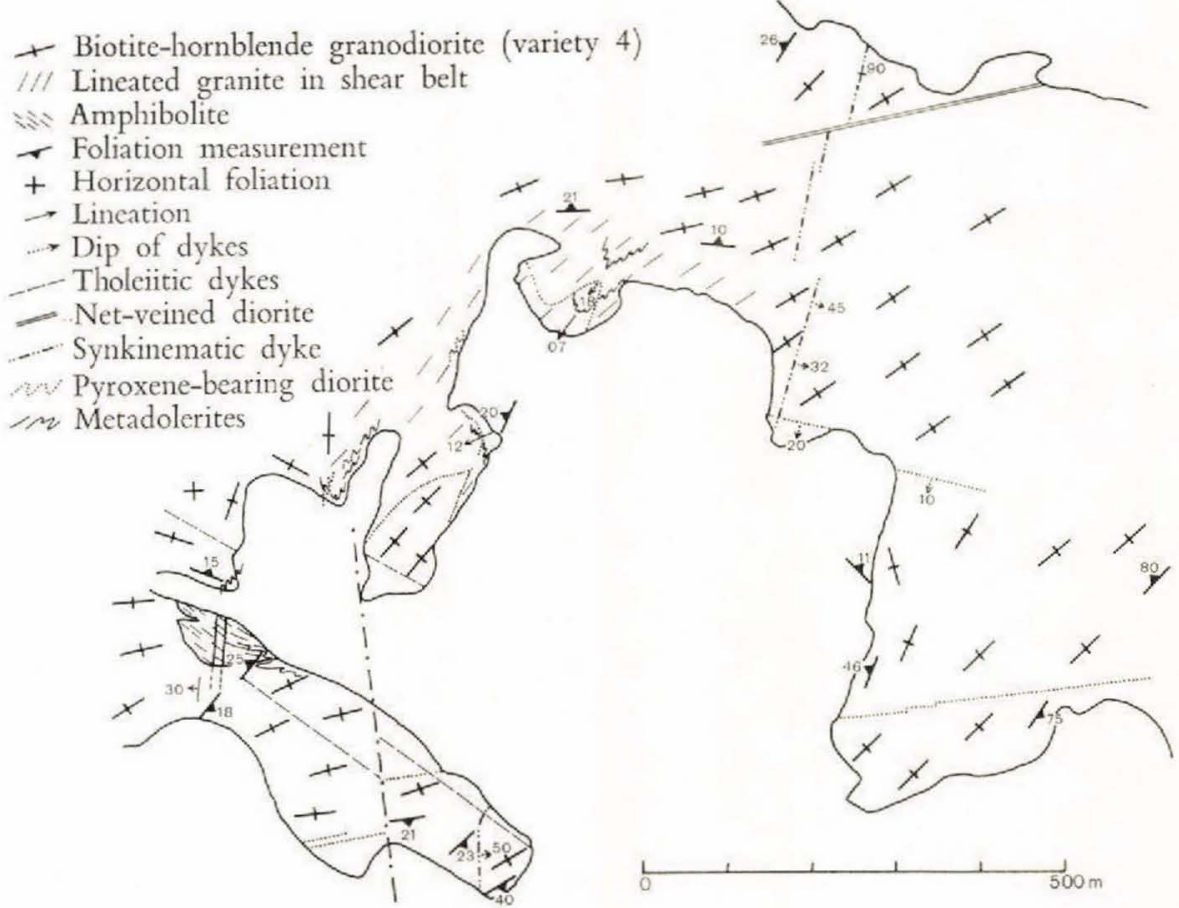

Fig. 30. Detailed map of the central part of Pârdlitt island.

the N-S trending synkinematic dyke from the south-western part of Julianehåb peninsula. Near the northern shore the dyke is crosscut by a roughly $\mathrm{E}-\mathrm{W}$ trending dyke of net-veined diorite. In many places the synkinematic dyke is dextrally displaced by ENE to E-W trending cross-shears which crosscut the foliation in the granite. Some of the displaced fragments show clear signs of disorientation (see fig. 31) as a result of remobilisation in the host rock active after the formation of the shears. At the same time recrystallisation in the granite was able to remove evidence of most of the cross-shears which are now recognisable over stretches of only a few metres and which show all stages in their obliteration. In one place the course of the dyke is interrupted for $1 \mathrm{dm}$ by a pegmatite which is perpendicular to the trend of the dyke; the pegmatite does not continue into the granite and its margins, although slightly irregular, lie in line with the dyke contacts. These features show that on Pârdlit, in contrast to Julianehåb peninsula, slight remobilisation occurred after the emplacement of a synkinematic dyke. It is significant that the granite does not attack the dyke itself, and it appears as if the granite did not obtain that degree of aggressivity which is typical of the preceding phase of granite development. It is noteworthy that the cross-shears which displace the synkinematic dyke have the same 


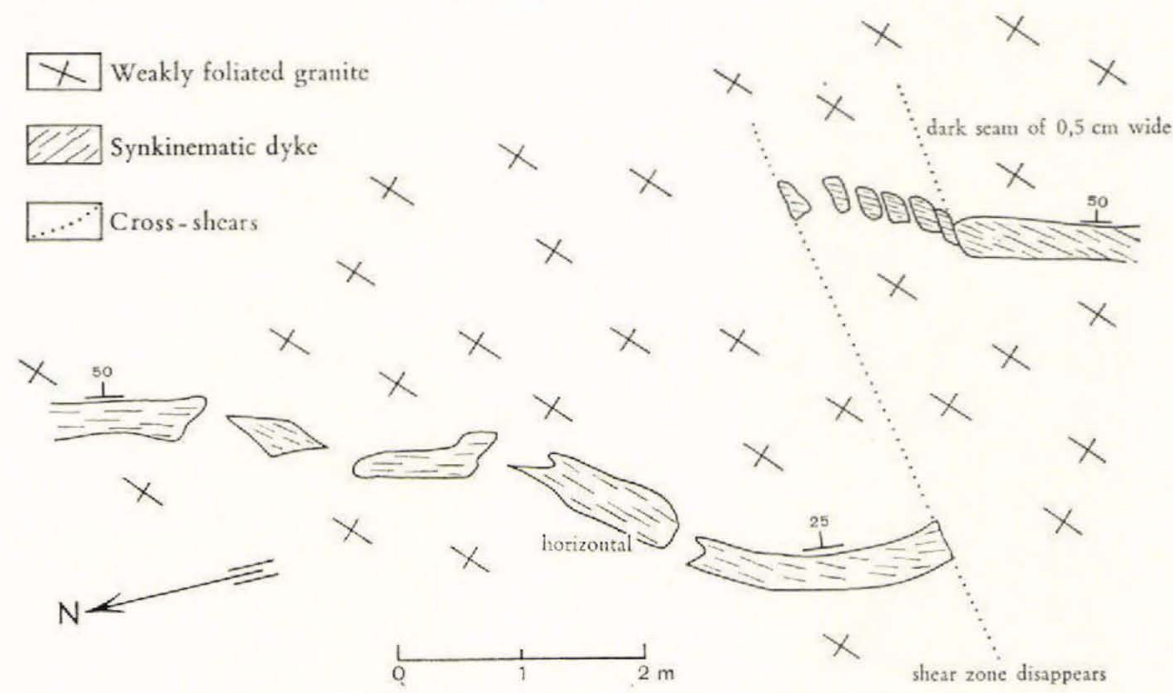

Fig. 31. Fragmentation of synkinematic dyke associated with sinistral eross-shears which crosscut the foliation in the granite (variety 4) and the foliation in the dyke. After the cross-shearing, mobility in the country rock resulted in disorientation of some of the dyke fragments. Pârdlitt island.

attitude as that of the fourth generation of synkinematic dykes from the south-eastern part of Julianehåb peninsula. Even the sense of displacement of the shears is the same as that indicated by the sigmoidal foliation in the latter dykes. This late stage of remobilisation has a similar chronological position as the emplacement of the Redekammen type granites (see table 4). The relation between the two events is however not completely clear.

At the northern side of the bay the synkinematic dyke crosscuts a thin, gently dipping sheet of pyroxene-bearing diorite which is locally migmatised by the country rock. The diorite is slightly recrystallised, but primary textures are well preserved, as was shown on p. 46. At the intersection there are no critical features which indicate whether or not the emplacement of the synkinematic dyke is separated from that of the diorite sheet by plutonic activity. However, a relatively thick E-W trending dyke of pyroxene-bearing diorite at the southern side of Pârdlît, belonging to the same generation as the sheet, was affected by an earlier phase of granite development, marked by extensive veining of the dyke by country rock granite (see section XII) in the absence of stress, and a later phase during which perpendicular pegmatites which do not continue into the granite were formed (fig. 47). As will be shown in the following section these phases are separated by a stage of brittleness and shearing. The nature of the synkinematic dyke requires its emplacement in connection with the stage of shearing and as the synkinematic dyke, in 
Metadolerite

Wiltit Pyroxene-bearing diorite

$\square$ Aplite

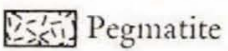

$\triangle 1 \backslash$ Lineated granodiorite

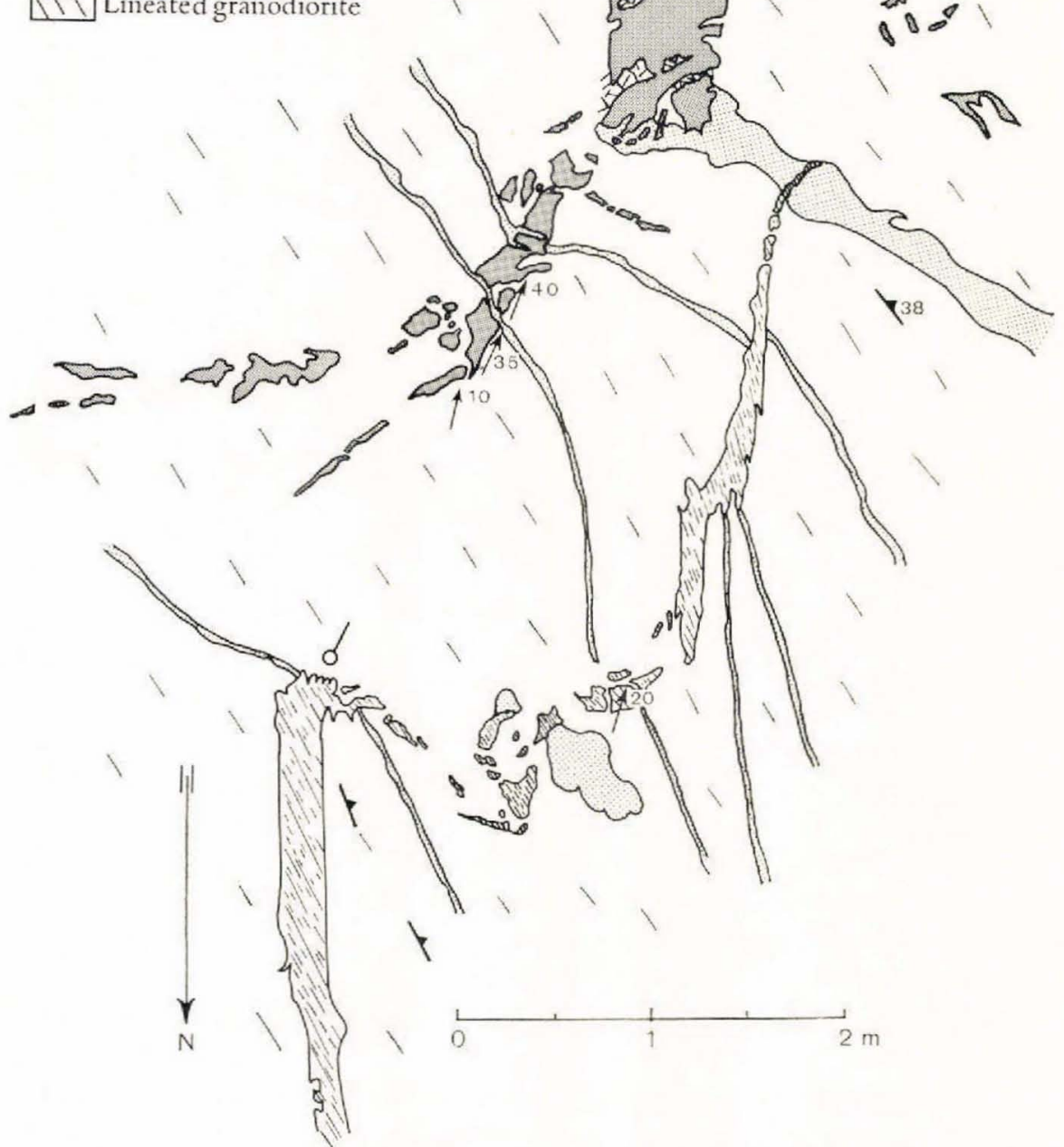

Fig. 32. Folded metadolerite and pyroxene-bearing diorite within shear belt of lineated hornblende-biotite granodiorite. Pàrdlit island. 


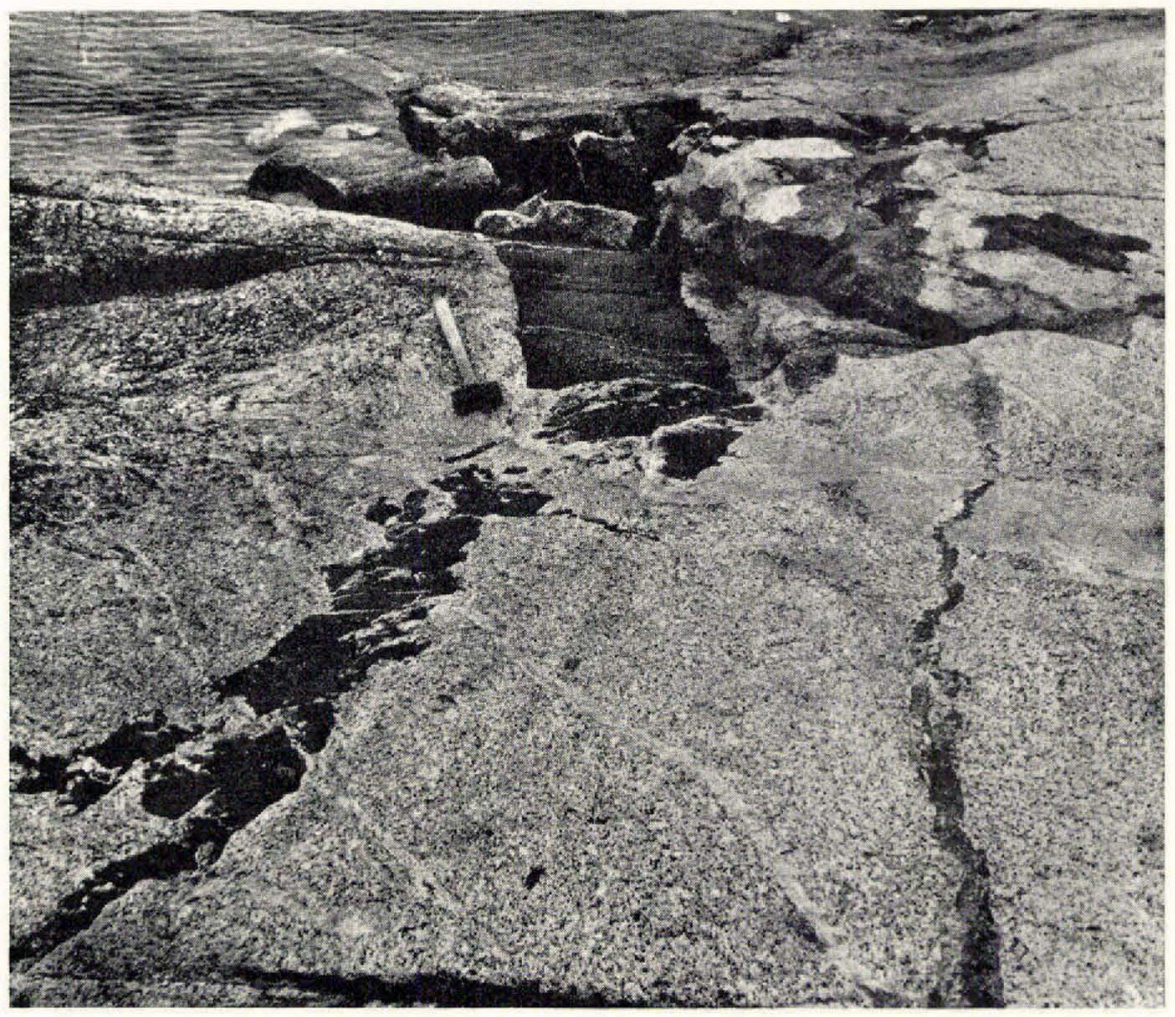

Fig. 33. Close-up of upper part of fig. 32 showing the metadolerite and crosscutting relations of pyroxene-bearing diorite to an aplite vein.

constrast to the two pyroxene-bearing diorite intrusive bodies, is not migmatised by the country rock, it is concluded that the pyroxenebearing diorites and the synkinematic dyke are separated by a phase of granite development. This phase must be the same as that referred to in fig. 29 on Julianehåb peninsula.

The thin sheet of pyroxene-bearing diorite continues under water and it reappears in several places in the shear belt at the north-western side of the central bay where it is locally folded (fig. 32). On the small peninsula at the western side of the bay the sheet sends out a vertical offshoot which leaves the belt continuing for a long distance crosscutting the foliation in the overlying granite. The thick diorite dyke mentioned above shows the same crosscutting relations to the foliation and concentrations of basic inclusions in the granite. Within the shear belt the diorite possesses a typical crystalloblastic texture produced by the deformation in the belt.

On the island fragments of metadolerite dykes are frequent. These have the same appearance and distribution as those from the south-west 


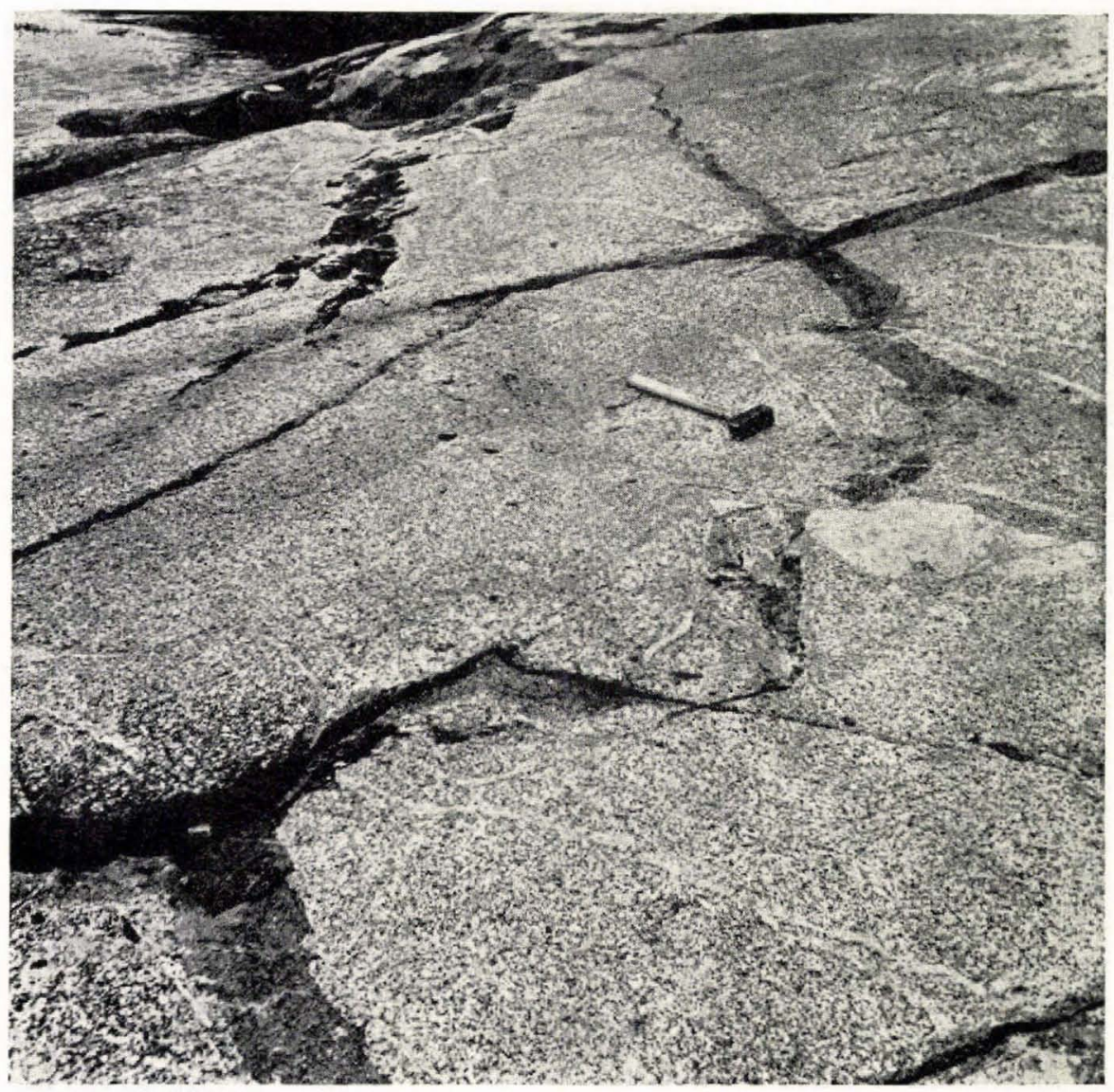

Fig. 34. Close-up of lower part of fig. 32 showing the folded and migmatised pyroxenebearing diorite.

side of Julianehåb peninsula. Most of them are slightly oblique to the granite foliation which is continuous with the internal foliation of the fragments, as can be seen in fig. 19. In some places there are isoclinally folded relicts of a relatively basic green coloured metadolerite. Outside the shear belt its fold axes trend NW, but inside it NW and NE axes have been recorded, suggesting that there it is double-folded. The degree of migmatisation of the folded body in the belt however did not allow this to be proved. The evidence that the body is a dyke relict is based on its relations to a large enclave of homogeneous amphibolite outside the shear belt on the elongate peninsula at the south-western side of the central bay (fig. 30). The basic body although strongly folded, crosscuts this enclave and continues for some distance into the surrounding granite. Moreover a fragment of it has a dyke-like form and a protrusion which extends into the lineated granite of the shear belt (fig. 32, 33). 

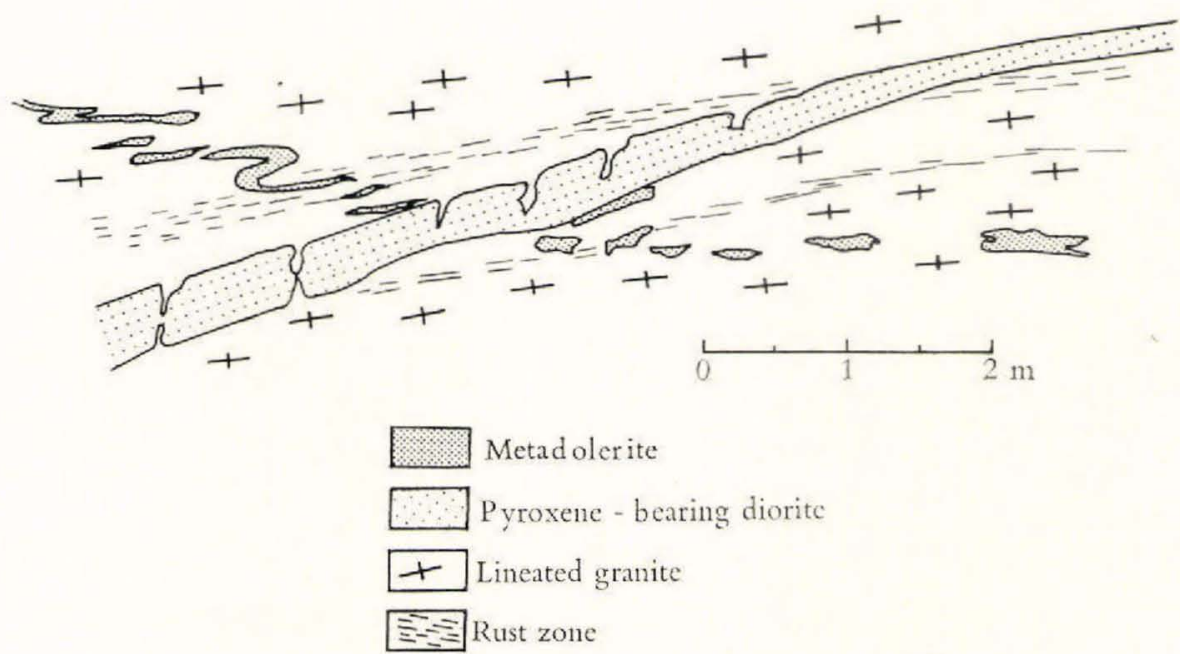

Fig. 35. Intersection (the north-easternmost shown in fig. 30) between the doublefolded (?) metadolerite and the sheet of pyroxene-bearing diorite in the shear belt. Pârdlìt island.

There are three intersections between the green metadolerite and the pyroxene-bearing diorite in the shear belt. The relations of the northernmost intersection (fig. 30) are shown in fig. 35. The diorite sheet which in this locality is parallel to the foliation in the granite truncates a fragment of the green metadolerite. This shows that the disruption of the metadolerite took place before the emplacement of the diorite. In fig. 32 where both intrusive bodies are folded about NE trending axes, it can be shown that leucocratic veins migmatise or crosscut the green metadolerite while they are transected by the diorite. The intrusion of the two intrusive bodies is thus separated by an episode of granite development marked by migmatisation (fig. 35), leucocratic veining (fig. 32,33 and 34 ) and by deformation. The continuity of the sheet and dyke of pyroxenebearing diorite which crosscut the foliation outside the shear belt contrasts strongly with the distribution of the widely spaced metadoleritic dyke fragments, the foliation of which is continuous with the foliation in the granite. It can therefore be concluded that the pyroxene-bearing diorites postdate the phase of granite development, already recognised on Julianehåb peninsula, during which the allochthonous granite was formed. The intrusion of the pyroxene-bearing diorites was in turn followed by a phase of granite development during which they were extensively migmatised, generally in the absence of deformation. During this phase the shear belt was probably formed. The emplacement of the synkinematic dyke was followed by cross-shears and subsequently passive mobilisation which caused generation of perpendicular pegmatites within the dykes and local disorientation of the displaced dyke fragments. 
The relations of the succession established on Mato island in the metamorphosed supracrustals (section X) to the chronology of the southwest side of Julianehåb peninsula and Pârdlît remains to be considered. The amphibolite relict dykes in these rocks are interpreted as pre- or early orogenic dykes. It is highly probable that the NW folding is earlier than the disrupted metadolerites in the adjacent granite. Possibly the NE folding is connected with the emplacement of the allochthonous granite which postdates the metadolerites. A few observations have however been made suggesting that before the intrusion of the metadolerites there might have been a phase of granitisation. These observations will be dealt with in the following section.

\section{The chronology of Avatarmiut and surroundings}

In this subarea there are thick sheets of net-veined diorite, two thin synkinematic dykes, laccolithic bodies and numerous sheets of pyroxene-bearing diorite and a few small plutons of hypersthene gabbro. The country rock on Avatarmiut and surrounding islands is a relatively mafic homogeneous granodiorite, classified as belonging to variety 4. On Niaqornap nunâ Big-feldspar granite (variety 5 ) is exposed.

In the Big-feldspar granite on a little island immediately east of Niaqornap nunâ the establishment of a local chronology has led to the recognition of a late stage of passive remobilisation of a similar nature as that already recognised on Pârdlitt. On this little island a thin synkinematic dyke extends continuously for $100 \mathrm{~m}$ from the northern to the southern shore. Its northern part trends NNW and its southern part N to NNE. There is also a thick sheet of net-veined diorite which sends out a few apophyses without net-veining. The synkinematic dyke is dextrally displaced by numerous cross-shears (fig. 36 ) with the same attitude as those on Pârdlit. The cross-shears were almost completely obliterated by subsequent recrystallisation in the granite accompanied by slight remobilisation, which resulted in the disorientation and floating apart of some of the dyke fragments. The fragmented dykelet is cut by two generations of leucocratic veins and is displaced by a hot shear zone with $\mathrm{N}-\mathrm{S}$ trend. The succession established is given in table 5.

The fragmentation of the synkinematic dyke has been shown to have taken place before the movement along the hot shear zone. In fig. 37 an aplite vein (belonging to 4 in the table) crosscuts a fragment of the dyke in such a way that it is evident that the fragmentation took place before the emplacement of the vein. In another place the aplite (4) is cut by a vein of microgranite ( 6 in the table). The apophyses of the netveined diorite sheet transect both the hot shear zone (5) and the veins of microgranite (6). The fragmented synkinematic dyke and the net-veined 


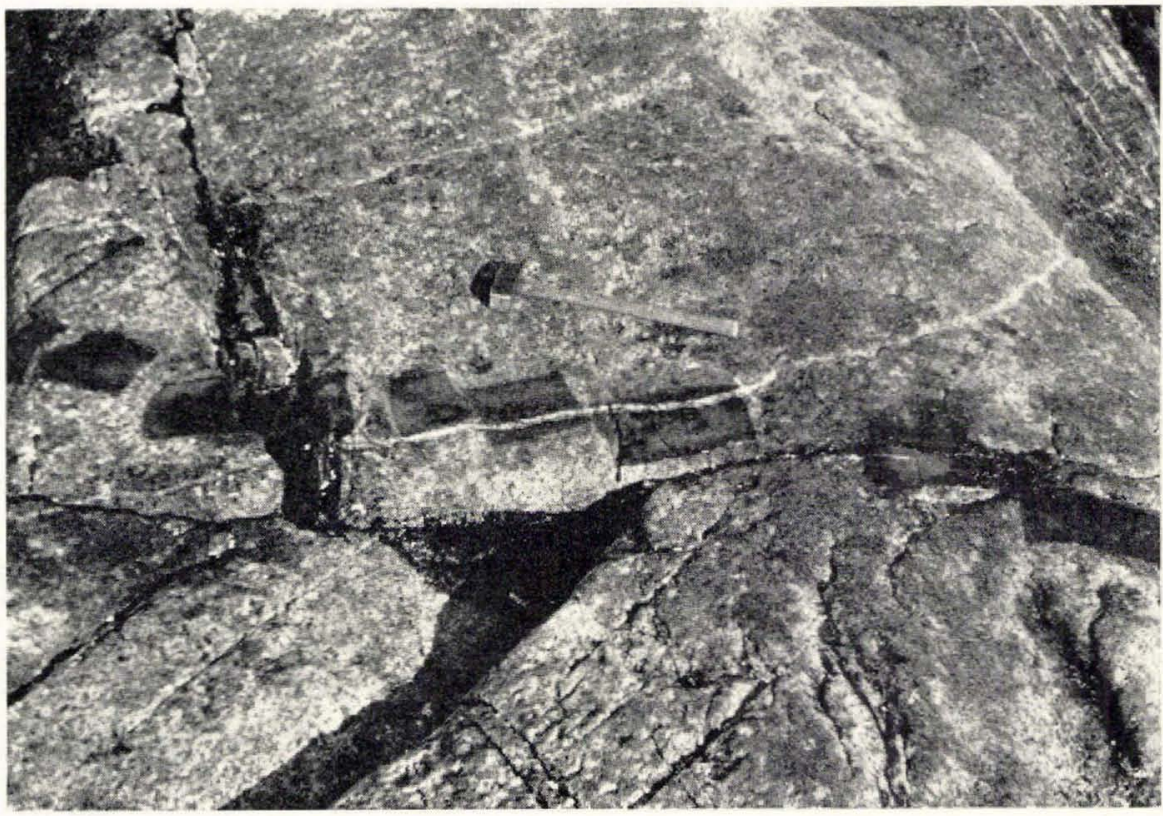

Fig. 36. NNW-trending synkinematic dyke displaced by cross-shears which were obliterated by subsequent recrystallisation in Big-feldspar granite. A few fragments were moved apart and another fragment is slightly disoriented. Small island east of

Niaqornap nunâ.

diorite are thus separated by an interval during which a stage of brittleness and cross-shearing was followed by remobilisation in the granite while subsequently during a second stage of brittleness leucocratic veins were emplaced and hot shear zones were formed.

The remobilised granite generally does not attack and migmatise the fragments of the synkinematic dyke, and nowhere do the big feldspars protrude into the dyke. The remobilisation is thus of the same passive character as that recognised on Pârdlit island.

In a locality on Niaqornap nunâ $2 \mathrm{~km}$ north of the little island just mentioned another synkinematic dyke occurs with the same trend and of the same width as that found on the little island. They must belong to the same generation. The little dyke on Niaqornap nunâ is occasionally erosscut by very thin veins which grade into the surrounding granite. In the dyke sigmoidal schistosity is well displayed. In numerous places the dykelet truncates big feldspars and it postdates therefore the main phase of crystallisation of the Big-feldspar granite. These relations of the dykes on Niaqornap nunâ and the little island (fig. 36) to their respective country rocks demonstrate that the dyke of the little island after its intrusion was affected by remobilisation in the host rock while 
Table 5. Local succession of events on an island east of Niaqornap nunâ.

8. Low-dipping pegmatite veins.

7. Net-veined diorite $(065 / 22 \mathrm{NW})$ the apophyses of which transect the mylonite zone (4) and microgranite (5).

6. Microgranite forming an irregular network of veins.

5. N-S trending hot shear zone displacing synkinematic dyke sinistrally for $7 \mathrm{~m}$.

4. Aplite veins (030/40SE).

3. Remobilisation in granite, disorientation and floating apart of some dyke fragments; obliteration of the cross-shears.

2. Cross-shears (ENE) displacing the dyke sinistrally.

1. Emplacement of synkinematic dyke in Big-feldspar granite.

the dyke of the locality first mentioned was not. This is taken as demonstrating a border to the area of remobilisation between the two islands. The observations on nearby islands to the west show that this border has a NE trend, as there signs of cross-shearing affecting sheets and dykes of pyroxene-bearing diorite are absent. The more or less restricted distribution of this late stage of remobilisation already recognised on Pârdlit and surrounding islands is thus confirmed by the observations in the Avatarmiut subarea. It is tempting to relate the mobilisation phenomena described above with the presence of a relatively large body of Redekammen granite on a nearby island farther to the east. More field work is however necessary to confirm this.

The relations between the net-veined diorites and pyroxene-bearing diorites from Avatarmiut and the southern part of Niaqornap nunâ are established by eight intersections in widely spaced localities. The netveined diorites show crosscutting relationships to 1) diffuse granite veins, 2) well defined veins of country rock granite and 3) the net-veins in the pyroxene-bearing diorites.

Outside the Big-feldspar granite the pyroxene-bearing diorites are undeformed; their primary textures are generally well preserved. Within the Big-feldspar granite they are deformed, boudinée and strongly recrystallised while occasionally big feldspars protrude into the diorite bodies. The pyroxene-bearing diorites appear therefore to predate the main phase of crystallisation in this granite.

In the subarea under consideration there are no traces of metadoleritic dykes which predate the pyroxene-bearing diorites. The crosscutting relationships of the diorite sheets to basic inclusions in the granite outside the main body of Big-feldspar granite suggest that there the country rock was granitic before the intrusion of the diorites took place. 


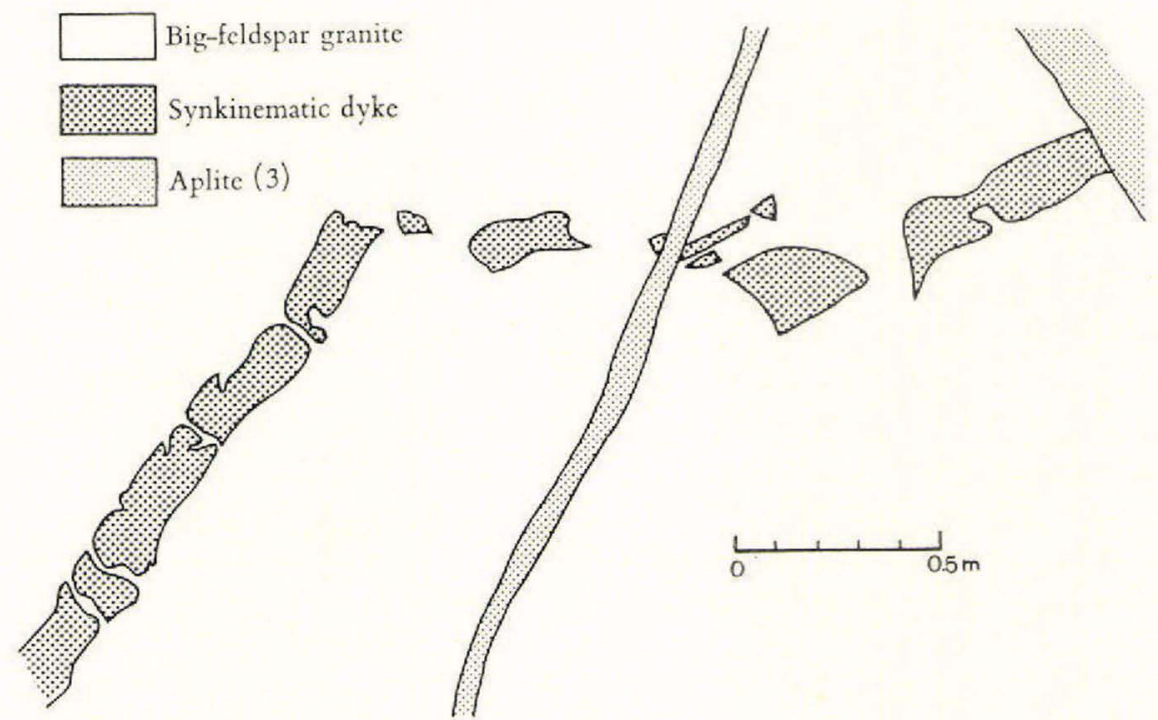

Fig. 37. Aplite veins postdating fragmentation of synkinematic dyke in Big-feldspar granite. Small island east of Niaqornap nunâ.

Summarising, the following succession has been established (third column of table 4). Brittle granitic country rock was intruded by numerous bodies of pyroxene-bearing diorite. This was followed by a phase of granite development during which the country rock granite became aggressive towards the diorite bodies. Probably contemporaneously with this the Big-feldspar granite was formed in connection with slight deformation within the main body. During a later stage of brittleness in the crust a few synkinematic dykes were intruded. Subsequently, one of these was fragmented by cross-shears and disoriented and moved apart during a late stage of passive mobilisation of restricted distribution. A final return to brittle conditions permitted formation of hot shear zones, emplacement of leucocratic veins and the intrusion of numerous sheets of net-veined diorite.

\section{The chronology of the outer parts of Bredefjord}

There are only net-veined diorites, metadolerite dykes and a possible pre- or early orogenic relict dyke in the outer parts of Bredef jord. As will be shown more extensively in the following section, the metadolerites are deformed. This deformation generally followed pre-existing foliation planes and took place under semiplastic conditions while competency differences between the basic bodies and host rock were almost nil. The country rock granite for the most part failed to reach a state in which it 
was able to migmatise and vein the dykes. In some places the deformation is followed by plastic movements in granite bands, especially those with a steep attitude, and some slightly larger areas of granite, resulting in disruption of the dykes in these bands and areas and tearing apart of the fragments. In general the distance over which they moved apart was small. In a few bands however the fragments occupy about $50 \%$ and in a slightly larger granite area $10 \%$ of the distance of the line along which they are arranged. Thus, in these places the granite tended to become intrusive. In other places where slight or no mobilisation took place the dykes are strongly veined by the country rock granite in the same way as the pyroxene-bearing diorites from other subareas. Finally cross-shears with NE, NW and N-S trends were successively formed, followed by local disorientation and bending of the dykes and their fragments. The phenomena described show great similarity to those developed during successive phases of granite development in the subareas of the preceding subsections.

Sheets and dykes of net-veined diorite crosscut the cross-shears. At intersections with metadolerite dykes they truncate or crosscut veins of country rock granite in the metadolerites. In some localities the metadolerites are folded and there the foliation in granite and gneiss bands is parallel to the axial planes of the folds. Nearby sheets and dykes of netveined diorite crosscut the foliation in the granite and the internal foliation of the metadolerites. In addition some of the diorites truncate big feldspars in the granite. The diorites thus postdate any of the events which during the successive phases of granite development affected the metadolerites.

In one locality along the south-eastern side of Bredefjord a doublefolded basic body occurs which was interpreted as a pre- or early orogenic dyke intruded into older granitic basement (section X). The two phases of deformation producing the folds in this probable relict dyke are postdated by the metadolerite dykes one of which crosscuts the relict dyke.

\section{The chronology of Torssukátak fjord and surroundings}

Along Torssukátak fjord and the fjord immediately to the northeast of it there is a great variety of basic and intermediate intrusives. However, the chronology of this subarea is not yet completely known.

In the inner part of Torssukátak fjord low-dipping gneisses are exposed for a distance of $2 \mathrm{~km}$. In the north-western part of the gneiss area fold axes trend NE to NNE while more to the south-west folds with ENE-trending fold axes are common and these refold the folds first mentioned. Along the next $3 \mathrm{~km}$ south-east of the gneiss area the nebulitic 

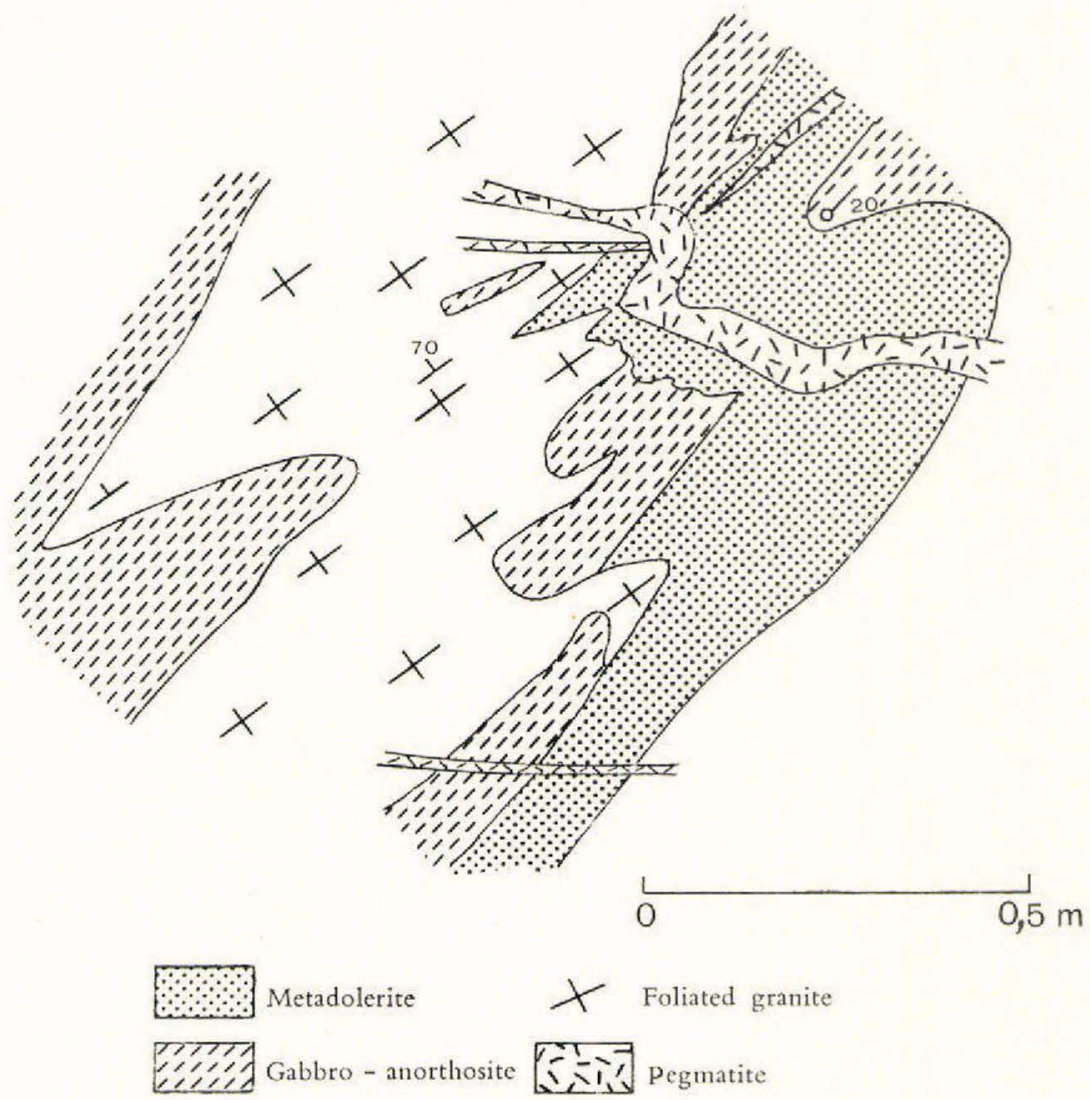

Fig. 38. Discordant relationships of a folded metadolerite to bands of gabbroanorthositic rock and granite in the nebulitic series (variety 1). North-eastern side of Torssukátak fjord.

series (variety 1), within which there are gabbro-anorthositic rocks, is exposed. Still farther to the south-east the country rock consists almost exclusively of granite. In the outer part of the fjord the nebulitic series is again found. The homogeneous granite occupies the core of an antiform. A little inland this core granite truncates a $70 \mathrm{~m}$ thick dyke-like body of metagabbro which is slightly discordant to the banding and foliation in the nebulitic series to the north-west of the homogeneous granite. This suggests that the core granite has broken through the antiformal structure. Towards the north-east the nebulitic series and the core granite are surrounded by a thick mantle of leucocratic granite which veins the adjacent Big-feldspar granite occurring to the north.

In the inner parts of the two fjords sheets and dykes of net-veined diorite and pyroxene-bearing diorite are frequent. At an intersection a dyke of net-veined diorite crosscuts a dyke of pyroxene-bearing diorite 
with its veins of country rock granite. In the gneisses of inner Torssukátak fjord five synkinematic dykes occur which are affected by the ENE folding.

In the granitic rocks along both fjords there are great numbers of late-plutonic dioritic sheets belonging to three successive generations. These crosscut the deformation structures, the regional foliation, the allochthonous core granite and the leucocratic mantle granite. In some places they are disrupted and migmatised by veins of the host rock granite which shows no signs of contemporaneous deformation. The sheets crosseut metadoleritic relict dykes occurring in the nebulitic series. The relict dykes show crosscutting relationships to older structures (see fig. 38) and to apophyses of the metagabbro mentioned above. In the allochthonous core granite there are a few straight-edged fragments of metadolerite and a relict of a fold hinge; the relations of these are similar to those of the disrupted metadolerites in the marginal facies of the allochthonous granite (variety 4) of Julianehåb peninsula. The metagabbro is also slightly discordant to the structures in the nebulitic series. The basic rock is foliated and this foliation is parallel to that in the surrounding rocks. There are a few leucocratic veins crosscutting the foliation in the metagabbro. Veins and foliation are in turn folded about ENE axes. Before the emplacement of the allochthonous granite the metagabbro has thus been affected by several plutonic events, while it seems that the metadolerites have only been affected by one phase of folding. It is therefore possible that the metagabbro and the metadolerites are separated from each other by a phase of plutonic activity. With the available evidence it is however not permitted to draw definite conclusions.

To summarise (first column of table 4), the NNE folding was followed by the intrusion of synkinematic dykes in the gneisses and of doleritic dykes in the nebulitic series. The former may be older than the latter. This was followed by ENE folding and by the emplacement of the allochthonous core granite. The formation of the thick mantle of leucocratic granite postdated the core granite and the Big-feldspar granite. Finally three generations of dioritic sheets were intruded and subsequently these were migmatised under quiet conditions in the absence of deformation. The chronological position of the metagabbro is not clear. It seems that the body is relatively early. Whether or not it predates the earliest observed phase of folding in the present subarea is not known.

\section{Correlation of the subareas}

In the preceding subsections the relationships between the various states of physical and chemical mobility in the country rocks, and the basic and intermediate igneous intrusive activity in each of the subareas have 
been outlined. In order to obtain a wider perspective of the evolution of the crust in time and space throughout the area investigated the significance of the different time markers, which can serve as a basis for the correlation of the local chronologies, has to be briefly examined.

Of the swarms of NW-SE trending tholeiitic dykes it has been shown that they are continuous throughout the area investigated and much farther to the south-east. It is highly probable that they also continue towards the north-west and that the swarms extend far beyond the boundaries of the Ketilidian mobile belt.

The net-veined diorites have a more restricted distribution. As WINDLEY (1965) has shown, they are arranged in an almost complete garland surrounding the eastern part of the Julianehåb district. The absence of mutual intersections combined with the high density of the intrusive bodies demonstrates that they represent an event of igneous activity of short duration. The net-veined diorites postdate the leucocratic granites of Redekammen type (variety 6), but in two bodies they were intruded before the final stages of solidification came to an end. The diorites also postdate the passive remobilisation affecting small patches of the crust over a wide area between Bredefjord and Pârdlit island. As will be shown later this granitic activity is mainly concentrated in the eastern part of the Julianehåb district. It seems that these various events represent different aspects of the latest stages of the plutonic evolution of the crust in a restricted part of the mobile belt.

The synkinematic dykes of Julianehåb peninsula and surroundings are mainly concentrated in the south-eastern part of the peninsula and, as far as can be seen, in the centre of the southern half of the JulianehåbIgaliko granite body (variety 4). The crust was brittle throughout the episode during which at least four successive generations of these dykes were emplaced in close connection with hot shearing and emplacement of several generations of leucocratic veins. There is no evidence contradicting the idea that at the same time conditions of brittleness prevailed in a much larger region farther to the west. The concentration of the synkinematic dykes in the centre of the body of allochthonous granite suggests that they are related with the termination of solidification processes in the body. However, before it was possible for the dykes to be intruded into the hot brittle granite, the influence of plutonic activity, centred around an area more to the west, interfered with the processes operating in at least the westernmost part of the allochthonous granite body. The synkinematic dykes occurring in the centre of the Qarmat body might have a similar relation to its allochthonous core (variety 4) as the synkinematic dykes of Julianehåb peninsula to the allochthonous granite there. However, in the Qarmat body remobilisation of the granite took place after the intrusion of the dykes. This process might have been connected 
with the formation of the thick mantle of aplitic granite which is thought to be considerably later than the core granite.

The late-plutonic diorite sheets (table 4, first column) from Torssukátak fjord and the fjord to the north-west do not seem to have a close relation with the allochthonous granite body which is correlated with the allochthonous granite of Igaliko and Julianehåb peninsulas (variety 4). The sheets postdate the broad mantle of aplitic granite which surrounds the allochthonous body. If this mantle is of similar age as the Redekammen type granites the sheets are considerably later than the synkinematic dykes of Julianehåb peninsula. After their emplacement the diorites were affected by cross-shearing and by migmatisation by the country rock granite and local disorientation of sheet fragments.

The pyroxene-bearing diorites occur in a crescent shaped area which partly overlaps the southern and western side of the main body of Bigfeldspar granite. Their field relations suggest that they predate the main phase of crystallisation of this granite. The evidence presented cannot however be considered as being completely conclusive. Therefore the possibility has to be considered that the formation of some of the big feldspars within the main body predated the intrusion of the diorites, which thus might represent a break in the history of the formation of the Big-feldspar granite. The significance of this break is as yet an unsolved problem; however the distribution of the pyroxene-bearing diorites accentuates their relation with the formation of this granite. The diorites predate a phase of granite development marked by high aggressivity of their host granite generally in the absence of deformation. This phase can also be recognised in the metadolerites along Bredef jord and even on the south-west side of Julianehåb peninsula where it predates the intrusion the synkinematic dykes. It is suggested that this phase is closely connected with the main phase of crystallisation of the Bigfeldspar granite.

The pyroxene-bearing diorites form a dense network of sheets and dykes and the absence of mutual intersections demonstrates that they represent one phase of igneous activity of short duration.

On Pârdlit and surroundings it could be shown that the pyroxenebearing diorites postdate the allochthonous Julianehåb-Igaliko granite body, the emplacement of which is controlled by a pre-existing antiformal structure. This body postdates metadolerite dykes which were disrupted and torn apart over great distances during its emplacement.

There are no pyroxene-bearing diorites along the outer parts of Bredef jord. The chronological position of the metadolerites from that subarea seems therefore uncertain. It has to be noted, however, that the Bredefjord metadolerites are definitely not diorites. If they were contemporaneous with the pyroxene-bearing diorites they originated 
from a magma of clearly more basic composition than that of the diorites. The idea that the two groups of intrusive rocks are contemporaneous is ruled out by the facts that, firstly, the metadolerites of Bredef jord are very strongly recrystallised in contrast with the diorites and secondly, along Bredef jord the same phases of granite development can be recognised, postdating the metadolerites, as on Pârdlit. Therefore the metadolerites of the different subareas can be considered as being roughly contemporaneous. If not, two or more episodes of dolerite intrusion should also have been recognised in other parts of the mobile belt; this is not so, as will be shown in the final section.

In the Pârdlitt and Julianehåb subareas the metadolerites postdate folding of gneisses and supracrustals of voleanic origin and probably also granitisation. In the Bredefjord and Torssukatak subareas the metadolerites were intruded into a series of gneisses and granites in which at least two phases of deformation ( $\mathrm{NE}$ and $\mathrm{NW}$ folding) can be recognised.

The chronological position of the hypersthene gabbros is an unsolved problem. Intersections of these with metadolerites and pyroxene-bearing diorites have not been found. The gabbro plutons occur either within the Big-feldspar granite or within and close to the margins of bodies of earlier allochthonous granites (variety 4). Original features and textures are generally well preserved in the basic bodies; however, smaller or larger parts of any of these are migmatised by their host granite. Two gabbro plutons within the Big-feldspar granite have only been affected by the host rock to a minor degree. A third occurrence of hypersthene gabbro consists of an agmatised mass. Numerous big feldspars have been observed protruding into strongly transformed enclaves of this mass. A fourth occurrence is interpreted as being a fragment torn apart from another body. Its original attitude seems to have been changed as a result of mobilisation in the granite. It is impossible to prove that these movements were connected with the generation of the Big-feldspar granite. It is just as possible that this fragment obtained its present position during a phase of granite development of the same age as the allochthonous granites belonging to variety 4. Regarding the hypersthene gabbro body within the allochthonous granite of Julianehåb peninsula NesbitT (1961) reported that along the greater part of the margin of the basic body coarse-grained gabbro is directly in contact with the host granite. It seems that large parts, including the margins, were stripped off this body. Locally there is also veining by the granite. In addition the greater part of the basic body was transformed into amphibolite. These relations might suggest that the gabbro predates the allochthonous granite.

It is therefore probable that some of the hypersthene gabbro plutons predate the allochthonous granite (variety 4). They might thus be close 
in age to the metadolerites. The basic plutons are concentrated in an ENEtrending belt (plate 3 ) roughly coinciding with the south-eastern part of the oval-shaped garland formed by the net-veined diorites. It is possible that some plutons postdate the allochthonous granites belonging to variety 4 and that these are practically contemporaneous with the pyroxenebearing diorites. Absence of deformation phenomena in the plutons is taken as a reason why they cannot be older than the metadolerites.

An important result of the investigations is that only the very young tholeiitic dykes appear to be proper time markers. The other basic and intermediate intrusives, although very important for the chronology in restricted areas, are of local distribution and appear to be closely associated with specific stages of granite development of local or regional distribution. Certain sorts can be distinguished, such as the net-veined diorites and the synkinematic dykes, which are connected with terminating stages of granite development, while others such as the pyroxenebearing diorites accompanied the early stages of phases of granite development. The significance of the metadolerites has however to be examined more closely, because metadoleritic dykes are reported to be of wide distribution in large parts of South Greenland. Before this can be done the possibilities of a large scale correlation with the adjacent regions have to be considered (see final section). 


\section{GRANITE DEVELOPMENT DURING THE 2ND EPISODE OF PLUTONISM}

As will be explained in the next section, the intrusion of the metadolerites reflects a tendency towards tectonic rest and brittleness, and probably a retreat of the geo-isotherms in the crust. This was followed by a long episode during which reconstitution of older granites and emplacement of granite bodies took place. These processes, of varying distribution in time and space, were closely related with basic and intermediate igneous activity.

\section{Distribution of granitic rocks predating the metadolerites}

An attempt has been made to show that the double-folded basic body of Bredefjord was originally probably intruded into host rock which had previously been granitised (plate 1, fig. 25). This host rock is a band in the nebulitic gneiss series.

In the nebulitic gneiss series (variety 1) and the foliated porphyritic granodiorite (variety 2) exposed along Bredef jord and on Igaliko peninsula the metadolerites crosscut alternating bands of granite and gneiss. In the most homogeneous granite bands the degree of migmatisation in the crosseutting dykes is generally not greater than in the gneiss bands, although it can be shown that movements, postdating the dykes, along older foliation planes have taken place (fig. 41). This suggests that the homogeneity in the granite bands was attained before the intrusion of the metadolerites. It is impossible to prove whether or not the granite bands already had an appearance or texture identical to that at the present day, but most probably they were gneissose granites or granitic gneisses. It is however certain that the nebulitic series obtained its character of alternating bands of gneiss and gneissose granite before the intrusion of the metadolerites.

As metadolerites are rare in large areas of homogeneous granite in the eastern part of the Julianehåb district, it is impossible to prove that homogeneous granites had already a regional distribution at the end of the 1st episode of plutonism. The only place where some evidence can 
be obtained is in the north-western marginal zone of the allochthonous granite of Julianehåb peninsula (variety 4). In this zone the fragments of the disrupted metadolerites are recrystallised, but generally unaffected by replacement processes. In addition some of these metadolerites show crosscutting relationships to inclusions of amphibolitic supracrustal rocks as is for instance shown in fig. 17. The presence of nearby dyke fragments which are well preserved in the surrounding granite suggests that the supracrustal rocks were already granitised before the intrusion of the metadolerites.

Therefore it can be concluded that at least in some areas granites had been formed before the end of the 1st episode of plutonism (see also p. 119).

\section{Deformation, and emplacement of early 2nd episode allochthonous granites}

The earliest stages of the 2nd plutonic episode are marked by deformation phenomena which are mainly concentrated in areas where gneisses and the granite varieties 1 and 2 are exposed. These surround ENE-trending areas of homogeneous granite in which foliation is generally weakly developed. Some of the latter granite areas comprise allochthonous bodies which were emplaced either in close connection with or slightly after the deformation. The deformation produced a planar foliation generally with $\mathrm{NE}$ or ENE trend, parallel to the main trends of pre-existing structures.

Only the relations of the metadolerite dykes to the deformation phenomena can elucidate its nature and intensity. This has already been demonstrated by WATtERson (1965) who has given a detailed analysis of the behaviour of metadoleritic dykes in the granite in the vicinity of Ilordleq at the north-western side of the region of Julianehåb granite. In the area investigated and in the area between Igaliko Fjord and Unartoq F jord there are a few important differences in the state of the country rocks during the deformation when compared with that around Ilordleq. Therefore the phenomena which are characteristically developed along the outer parts of Bredef jord, where great numbers of metadolerites occur, will be described in some detail.

The intensity of the deformation varies from place to place. These differences can for instance be deduced from the different styles of folding observed in the metadolerite dykes. In a few places along the southern shore of the fjord those parts of the dykes which were at right angles to the earlier and reactivated foliation (i.e. had a critical position to the regional stress field; see WatTERson, 1965: fig. 20, p. 46, f.) were folded with an open style an example of which is shown in fig. 39 . The foliation 


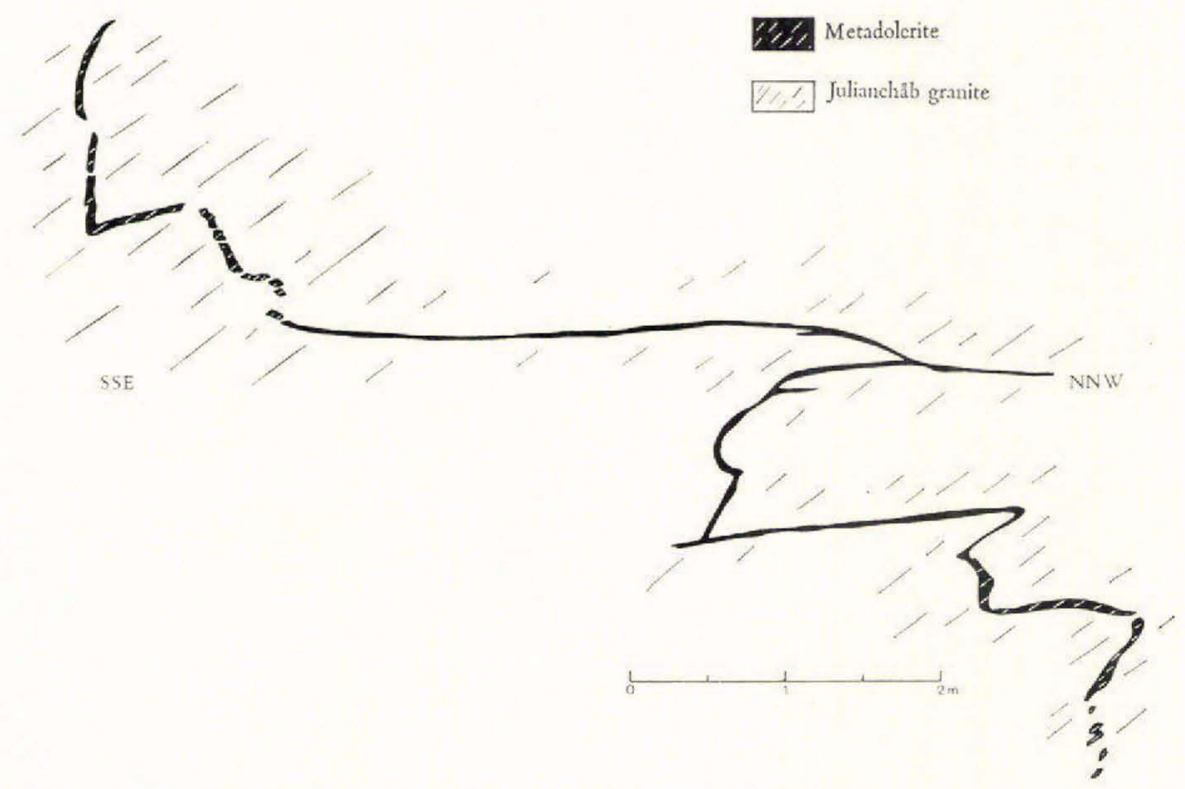

Fig. 39. Fracture-filling system of metadolerite which in places is thrown into open folds. Lille Tugtutôq, south-eastern side of Bredef jord.

in the country rock is parallel to the axial plane of the folds. This open style of folding suggests a relatively weak degree of deformation. Where the dykes are folded the amphibolite is schistose parallel to the foliation in the country rock. There is also a clear difference in behaviour between thicker dykes a few metres or more in width and thinner dykes less than $0.5 \mathrm{~m}$ wide. None of the thicker dykes observed along this shore is folded while thinner dykes with exactly the same direction as their thicker neighbours are folded. Apparently the compression was not strong enough to influence the thicker dykes.

Along the opposite side of the fjord the deformation was more intense. The deformation is here localised mainly in zones of coarsely porphyritic granodiorite up to a few hundred metres wide, which alternate with zones of non-porphyritic or slightly porphyritic granodiorite and gneiss. In the former zones the metadolerite dykes are locally thrown into isoclinal folds (see fig. 40) and the 2nd episode foliation, marked by a mineral orientation, continues through the hinge zones of the folded amphibolite. In the porphyritic granodiorite it is possible to recognise 1st episode structures marked by alternating bands of granite with variable composition and of gneiss and banded amphibolite. It is significant that the 1st episode structures and the 2nd episode foliation are completely parallel. In the granite there is a considerable number of metadolerites which can be followed for long distances along the well 


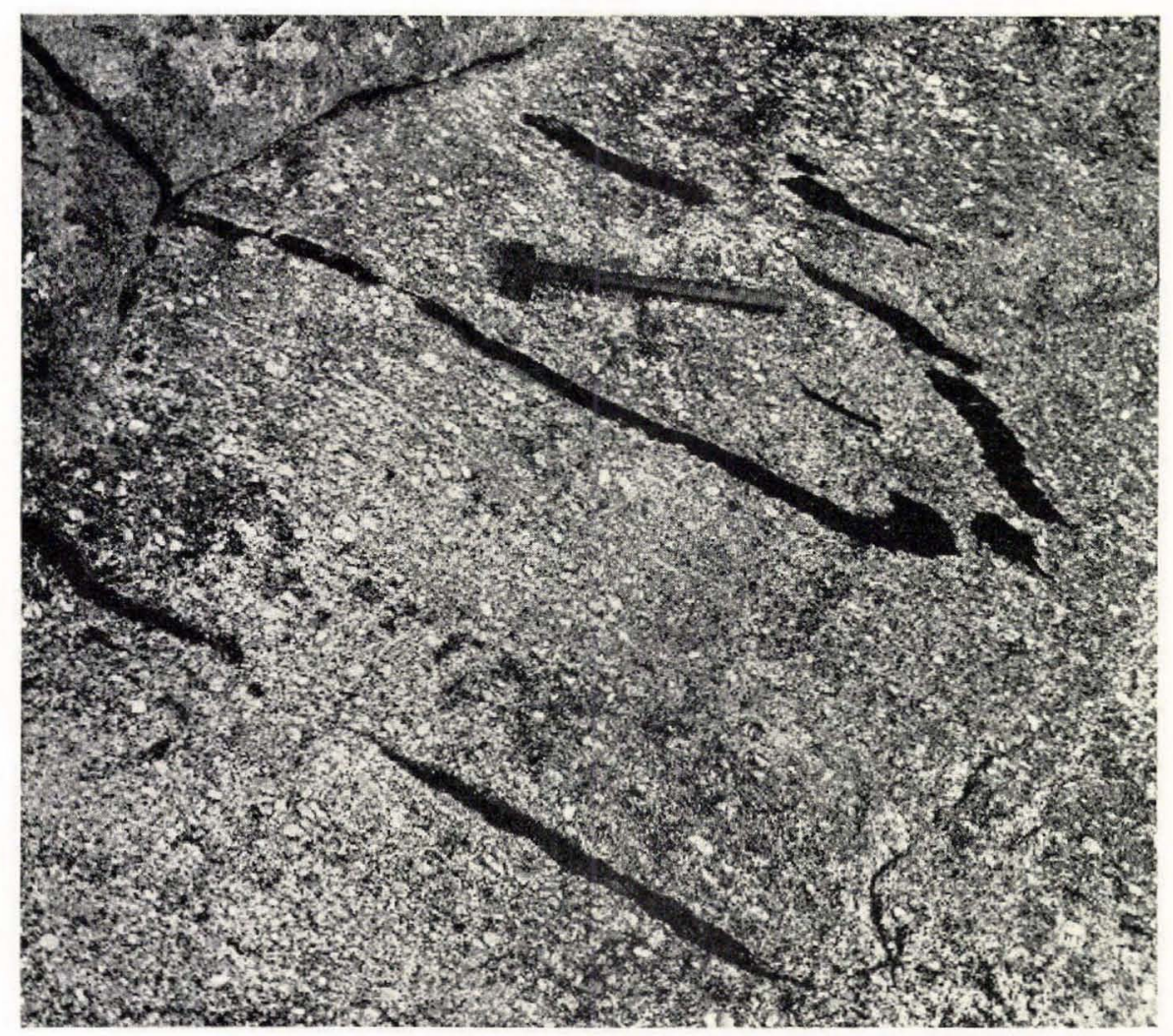

Fig. 40. Isoclinally folded metadolerite in Big-feldspar granite (variety 5). Qaersuarssuk, north-western side of Bredef jord.

exposed coast sections. Without exception these dykes are discordant, clearly crosscutting the older banding and gneiss structure. The discordance of the unfolded parts of the metadolerites is always slight, suggesting that the dykes became subparallel to the granite foliation as a result of relatively intense deformation. Alternatively at least some dykes must have been emplaced parallel to the 1st episode structures, which during the episode of intrusion of the dykes would certainly have been a direction of easy fracturing, unless the crust was under plutonic conditions and relatively hot.

In the Julianehåb granite along both sides of Bredefjord many similar examples of compositional banding older than the metadolerites have been found. That this banding is 1st episode in age is shown by the fact that where the metadolerites transect the different bands their degree of granitisation is the same in the leucocratic as in the melanocratic bands (see fig. 41).

The deformation took place under semi-plastic conditions. The competency differences between dykes and host rock were small or nil. 


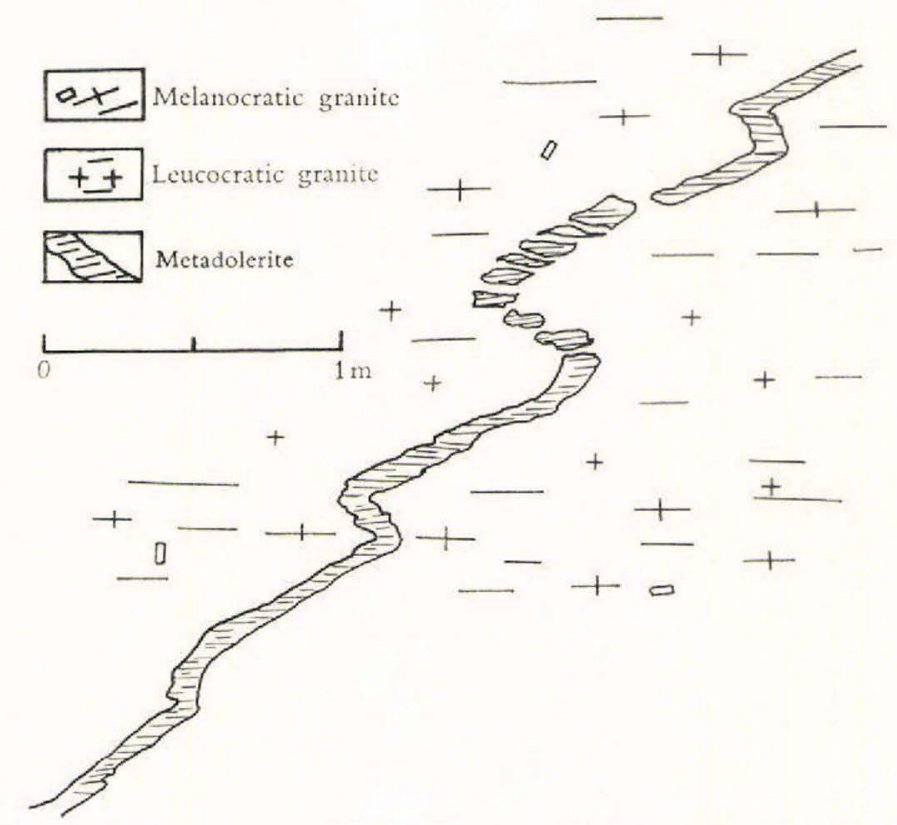

Fig. 41. Banded granite crosscut by folded metadolerite dyke. The degree of migmatisation is the same in both the leucocratic and melanocratic bands of the granite. Lille Tugtutôq, south-eastern side of Bredef jord.

Internal deformation produced schistosity in the dykes generally parallel to the foliation. In those dykes, the original position of which was not very different from the subsequent foliation, a considerable amount of stretching is possible (DE SitTeR; 1964, fig. 215), but without development of boudinage. Occasional dyke fragments which are torn apart have tapering ends. The temperature in the crust was however apparently not high enough to produce migration of granitic material. This is especially clear in a few localities which escaped recrystallisation connected with later phases of granite development. In these localities most of the megacrysts in the granite (variety 2 ) were reduced to augen. The degree of recrystallisation and reconstitution was thus clearly less than in the most strongly reconstituted granites from inner Kobberminebugt described by WATTERSON (1965) where metadolerite dykes were extensively migmatised contemporaneously with the deformation.

In a few places along Bredef jord the deformation is closely followed by plastic movements in some granitic bands, especially in those with a steep or vertical attitude and also in some slightly larger areas of granite. This resulted in disruption of the dykes and floating apart of the fragments which were far more competent than the host rock. The mobilised granite generally failed to replace or migmatise the dyke 


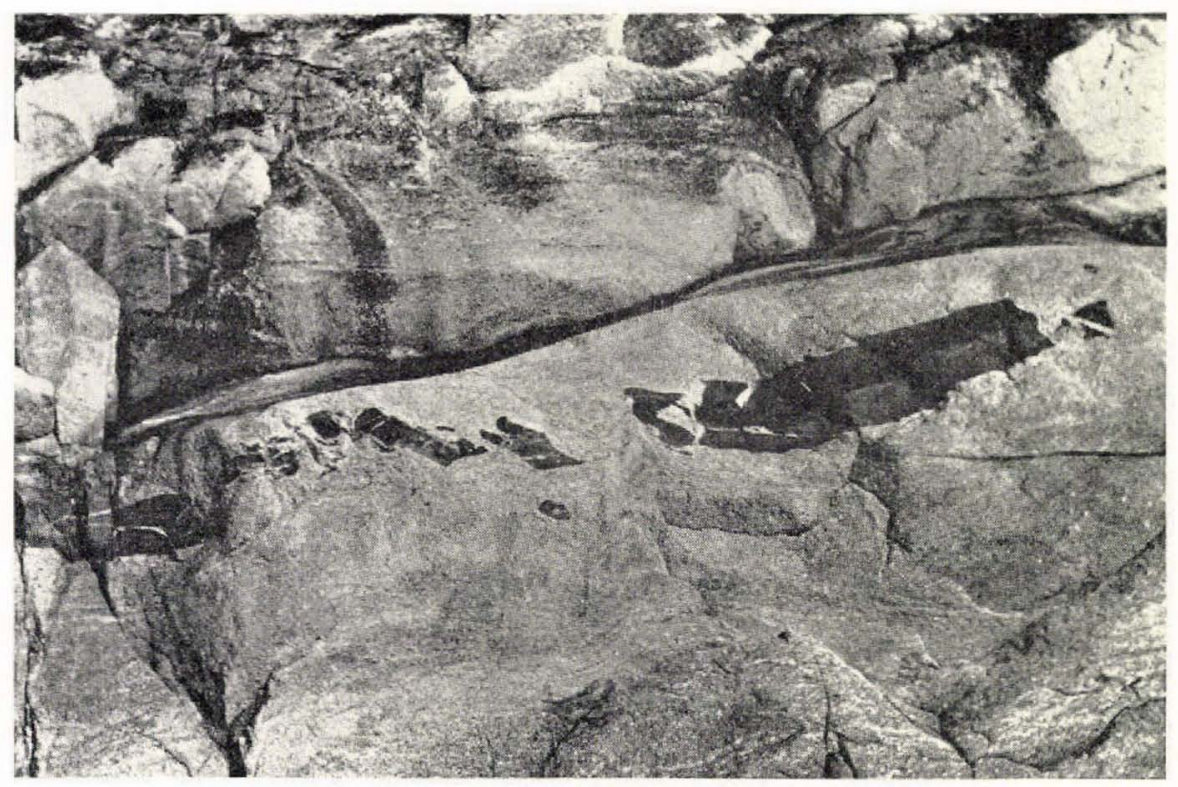

Fig. 42. Early stages of tearing apart of metadolerite fragments in granite which tends to become subautochthonous to allochthonous. Qaersuarssuk, north-western side of Bredef jord.

fragments. As a rule the distance they moved apart was small. In a few places however the fragments occupy about $50 \%$ (fig. 42) and in some slightly larger granite areas only $10 \%$ of the length of the line along which they are arranged. Thus it seems that in these places the granite tended to become intrusive.

Also on a large scale allochthonous granite bodies were emplaced during the earliest stages of the 2 nd episode. The most important body occurs on Julianehåb and Igaliko peninsulas, and a smaller one around Torssukatak fjord. Possibly the first stages of emplacement of the Qarmat granite body took place at the same time. It has been shown in section XI that the position of these intrusive bodies was probably controlled by pre-existing antiformal structures. The marginal phase of the Julianehåb-Igaliko granite body consists of non-porphyritic granodiorite and contains numerous enclaves of amphibolitic supracrustals, acid gneisses, occasional quartzites and a great number of fragments of metadoleritic dykes which locally show crosscutting relationships to the enclaves. The absence of replacement phenomena in the dyke fragments suggests that during the intrusive activity the marginal facies of the body did not reach a state in which it was able to attack them. This supports the idea that at least the marginal facies of the 
allochthonous body obtained its granitic character during the 1st episode of plutonism. The core of this body is made up of porphyritic granodiorite. The regular distribution of scattered enclaves of basic rock recrystallised beyond recognition and the general homogeneity of the granodiorite suggest that homogenisation played an important role. The end of this early phase of granite development was marked by a slow process of consolidation during which the synkinematic dykes (section V) were eventually intruded mainly in the cores of the granite bodies. However, before the consolidation in the core of the allochthonous granite body of Julianehåb and Igaliko peninsulas had progressed far enough to permit the intrusion of the synkinematic dykes, brittle conditions in the crust between Pârdlitt and Bredef jord, and basic and intermediate igneous activity had already been succeeded by a new phase of granite development as will be shown later.

\section{The intrusion of the pyroxene-bearing diorites}

While consolidation processes still operated in the core of the Julianehåb-Igaliko granite body (and possibly also in the Qarmat body) the brittleness in the crust elsewhere permitted the intrusion of a hornblendite body in its western margin and also of a few laccolithic bodies and a dense network of dykes and sheets of pyroxene-bearing diorite. The main concentration of these is found between Pârdlitt and Lille Tugtutôq. A few dykes were also intruded along Bredef jord opposite the mouth of Torssukátak fjord and to the north of the latter fjord. They were intruded in the absence of stress and typical doleritic textures developed in many places, while locally along the margins of a few dykes shearing took place.

As has been mentioned before, the net-veins in the pyroxenebearing diorites bear a striking similarity to those of the net-veined diorites, the intrusion of which has been shown to be closely related to the formation of the net-veins. The following reasons suggest that the net-veins of the pyroxene-bearing diorites are also closely related to the emplacement of the diorite bodies. The pyroxene-bearing diorites were intruded during an interval of brittleness in the crust between two phases of granite development. That plutonic conditions also prevailed in the crust is suggested by the fact that in at least one nearby body of earlier allochthonous granite (Julianehåb), processes of consolidation, preceding the intrusion of the plutonic synkinematic dykes which postdate the diorites, were still operating (table 4). The occurrence of granite pipes in a few localities might suggest that the diorite, in at least those localities, was still partly mobile when the net-veins were formed (BLAKE et al., 1965, p. 35). 
When compared with the net-veined diorites which are much later in the chronology, the net-veining in the pyroxene-bearing diorites is developed on a much smaller scale and of less consistent distribution. It is noteworthy that leucocratic veining (aplites and pegmatites) was much more widespread and frequent during the intrusion of the net-veined diorites than during that of the pyroxene-bearing diorites. This might suggest that the net-veining in both groups of diorites was connected with activity of contemporaneous residual liquors. The differences in frequency of the net-veins in the two groups of diorite is then explained by differences in amount of the residual liquors in the crust during the respective episodes of intrusion.

As will be shown, phenomena like net-veining but of different origin can occur occasionally in metadolerite dykes. These phenomena are thought to be due to chemical activity of alkaline solutions derived from the adjacent granite during a phase of granite development subsequent to the intrusion of the dykes.

\section{The second phase of granite development}

The second phase of granite development is marked by the formation of the Big-feldspar granite and by extensive migmatisation of basic and intermediate dykes in a $15 \mathrm{~km}$ wide granitic belt surrounding the south-western and south-eastern sides of the main body of Bigfeldspar granite. The similar chronological position of these events might suggest that the migmatisation phenomena in the granitic belt are closely connected with the formation of the granite. The Big-feldspar granite and its origin have already been discussed in section II.

The pattern of the veining in the dykes of the granitic belt is variable. In thicker dykes, e.g. that of pyroxene-bearing diorite on Pârdlitt island (fig. 13), the country rock granite forms straight veins perpendicular to the contacts across the entire dyke. The veins are inter-connected by others lying parallel to the contacts, thus forming a network of two more or less perpendicular sets. Occasionally the pattern is less regular.

In thinner dykes, less than $1 \mathrm{~m}$ wide, the perpendicular veins are in places very common. They do not, however, always pass across the whole dyke as can be seen in fig. 15.

Usually veins of the country rock granite have sharp contacts. In some of the pyroxene-bearing diorites however, the veining is very irregular and diffuse.

At least some of the veins in the basic and intermediate intrusive bodies are of replacement origin as is suggested in fig. 43. Just below the centre of the photograph diorite fragments almost completely fill one such vein, while more to the left it is almost free of fragments. This unequal distribution of inclusions is very common in the veins. 


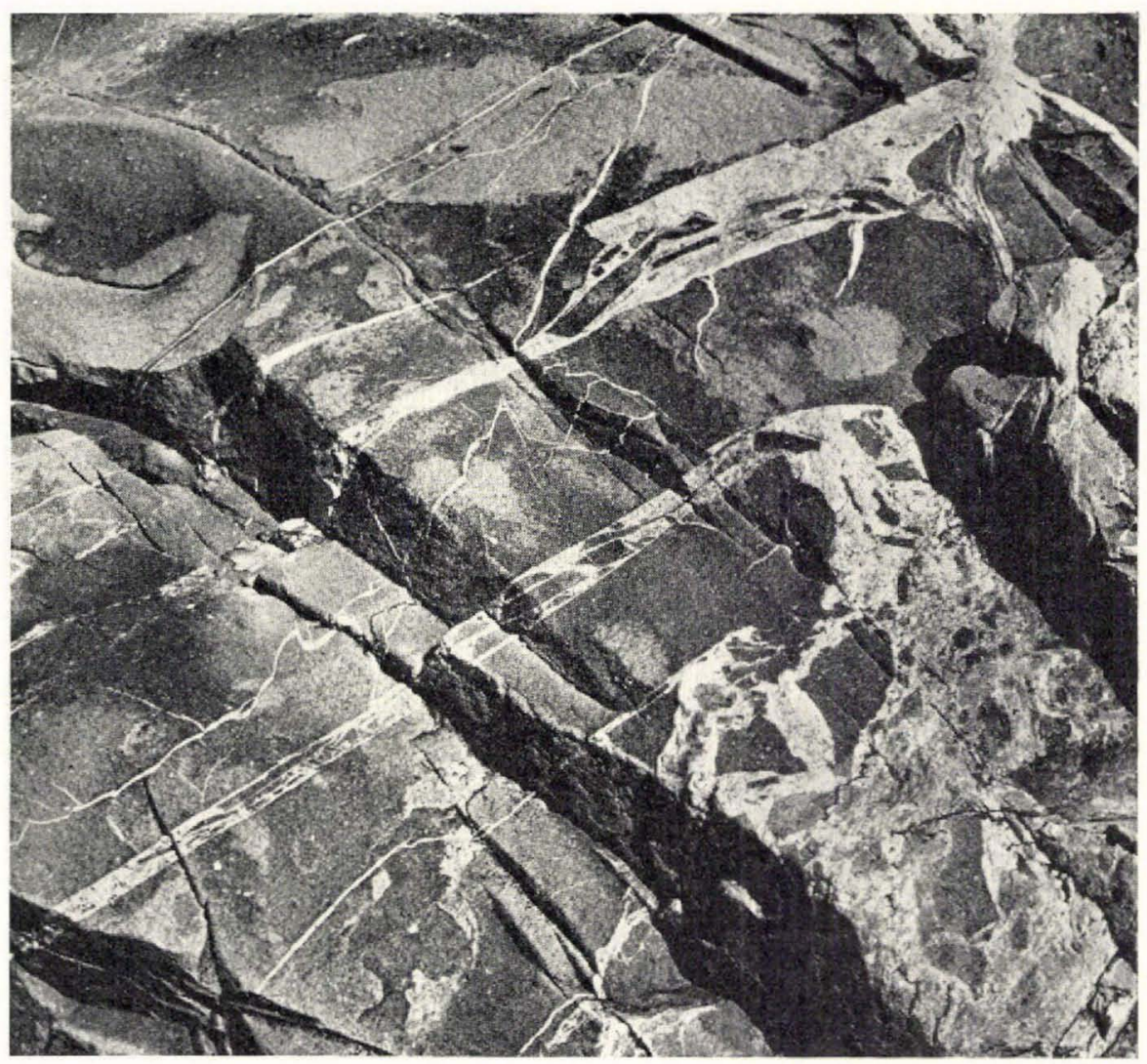

Fig. 43. Pyroxene-bearing diorite dyke with replacement veins of country rock granite parallel to its contacts. In the upper right corner flow movements are evident in one of the veins. Pârdlit island.

The geometrical relations in other veins clearly point to a dilational origin. It seems however that in these veins the granite was not intrusive, pressing apart the walls between which it penetrated. It is more probable that the granite invaded the fractures passively when the country rock was in a more or less plastic state, so that the fractures opened as a result of stretching in the host rock, which was clearly less competent than the dykes.

Generally the migmatisation of the dykes operated in the absence of deformation. The high aggressivity of the granite contrasts strongly with the behaviour of the granites mobilised during the earliest and the third phases of the 2nd episode of plutonism.

Here and there metadolerite dykes are migmatised by aplite or fine- to medium-grained granodiorite which are different in appearance 


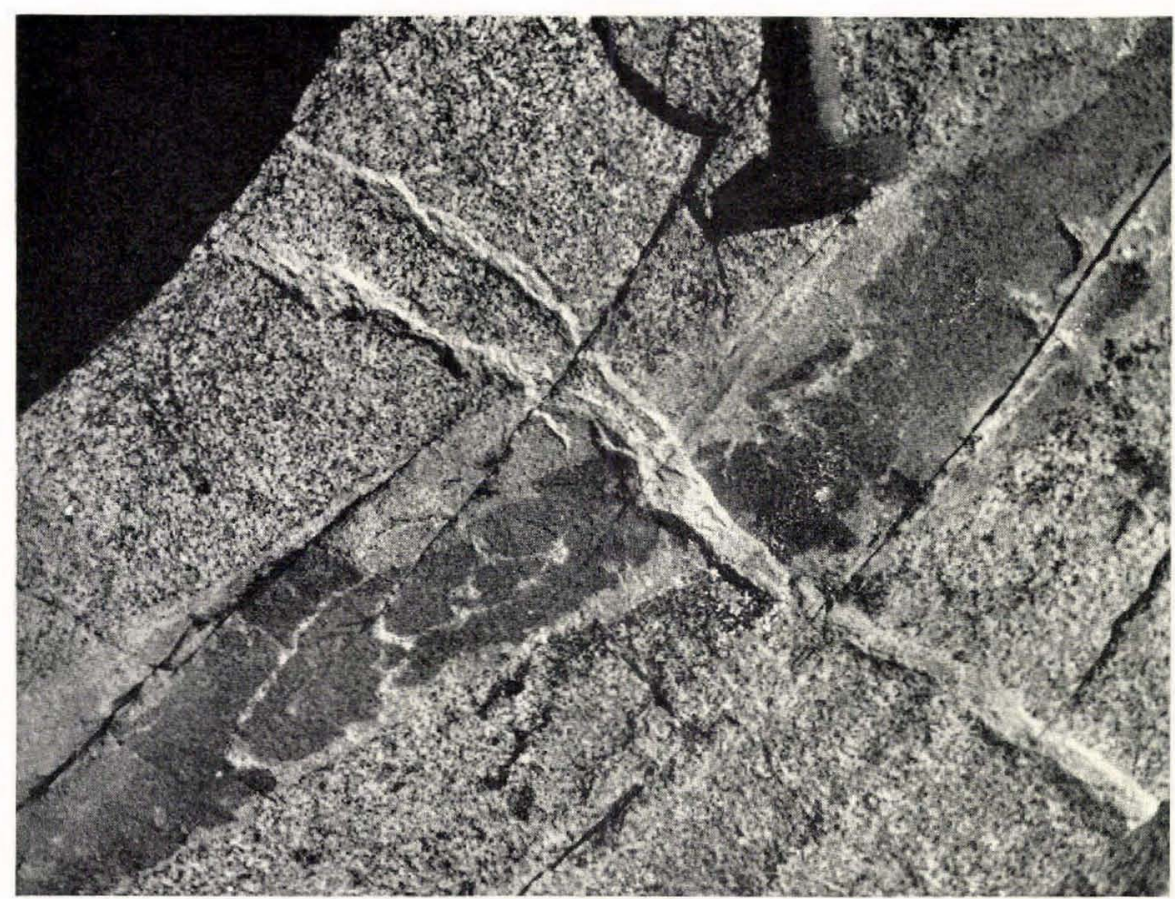

Fig. 44. Internal migmatisation in metadolerite dyke; the granite which replaces the dyke is clearly different from that of the country rock. Lille Tugtutôq, south-eastern side of Bredefjord.

and texture from the country rock granite. As a rule the migmatisation is localised along the margins of the dykes. The geometrical relationships of the granitic veins show that they are due to replacement of the dyke rock (see fig. 44). In all observed cases the influence of deformation seems to have been slight or nil. As these phenomena are only rarely developed, it has not been possible to establish their chronological relations. Possibly the migmatisation was connected with the second phase of granite development during which alkaline solutions derived from the adjacent granite attacked the dykes on a small scale. This explanation is that given by Ayrton and Burri (1967) for net-veined sheets from the Qagssimiut area.

\section{The synkinematic dykes}

While the second phase plutonic activity was operating in the area between Pârdlit and Bredef jord, consolidation in the core of the Julianehåb-Igaliko body of first phase allochthonous granite (variety 4) continued 
until several generations of synkinematic dykes were intruded in hot but brittle host rock. As has been shown in section $V$ the dykes were intruded in close connection with hot shearing and repeated emplacement of leucocratic veins. It has been demonstrated that the synkinematic dykes of Julianehåb peninsula postdate the second phase of granite development.

The occurrence far west of Julianehåb of a few synkinematic dykes probably equivalent to the third generation of the Julianehåb peninsula suggests that during the emplacment of this generation brittle conditions prevailed in the greater part of the area investigated.

\section{The latest phase of granite development}

The latest phase of granite development is marked by the emplacement of a few major bodies and numerous smaller bodies of leucocratic granite of Redekammen type (variety 6) and also by remobilisation of older granites in some areas.

An example of the remobilisation on Pârdlitt is shown in fig. 31, illustrating a synkinematic dyke displaced by cross-shears which cut the foliation in the allochthonous granite (variety 4). Some of the displaced fragments show clear signs of disorientation as a result of the subsequent remobilisation. At the same time recrystallisation in the granite was able to remove evidence of most of the cross-shears which are now only recognisable over stretches of a few metres and which show all transitional stages in their obliteration. Fig. 45 is taken from a small island immediately east of Niaqornap nunâ in the Big-feldspar granite (variety 5). In this locality a synkinematic dyke, possibly belonging to the same generation as that from Pârdlit, shows similar phenomena, but the recrystallisation has obliterated any trace of the cross-shears and also much of the original sigmoidal foliation within the dyke. In addition some of the fragments moved apart and others were completely disoriented. There are no indications that the fragments underwent mechanical deformation during this movement. The remobilised granite generally does not attack and migmatise the fragments of dykes.

Similar features have also been observed in ENE-trending metadolerites along Bredef jord (see fig. 46), but complete disorientation of the dyke fragments is very rare. In localities without remobilisation the cross-shears are well preserved. The course of the dykes, although continuous, is not always what one would expect of intrusive dykes. In a few localities the dykes show a slight but clearly developed undulatory course, seen for instance in plate 1. Parts of the dykes are clearly bent (fig. 46). This bending is so inconsistent that it cannot be related to the deformation during the earliest stages of the 2 nd plutonic episode. 


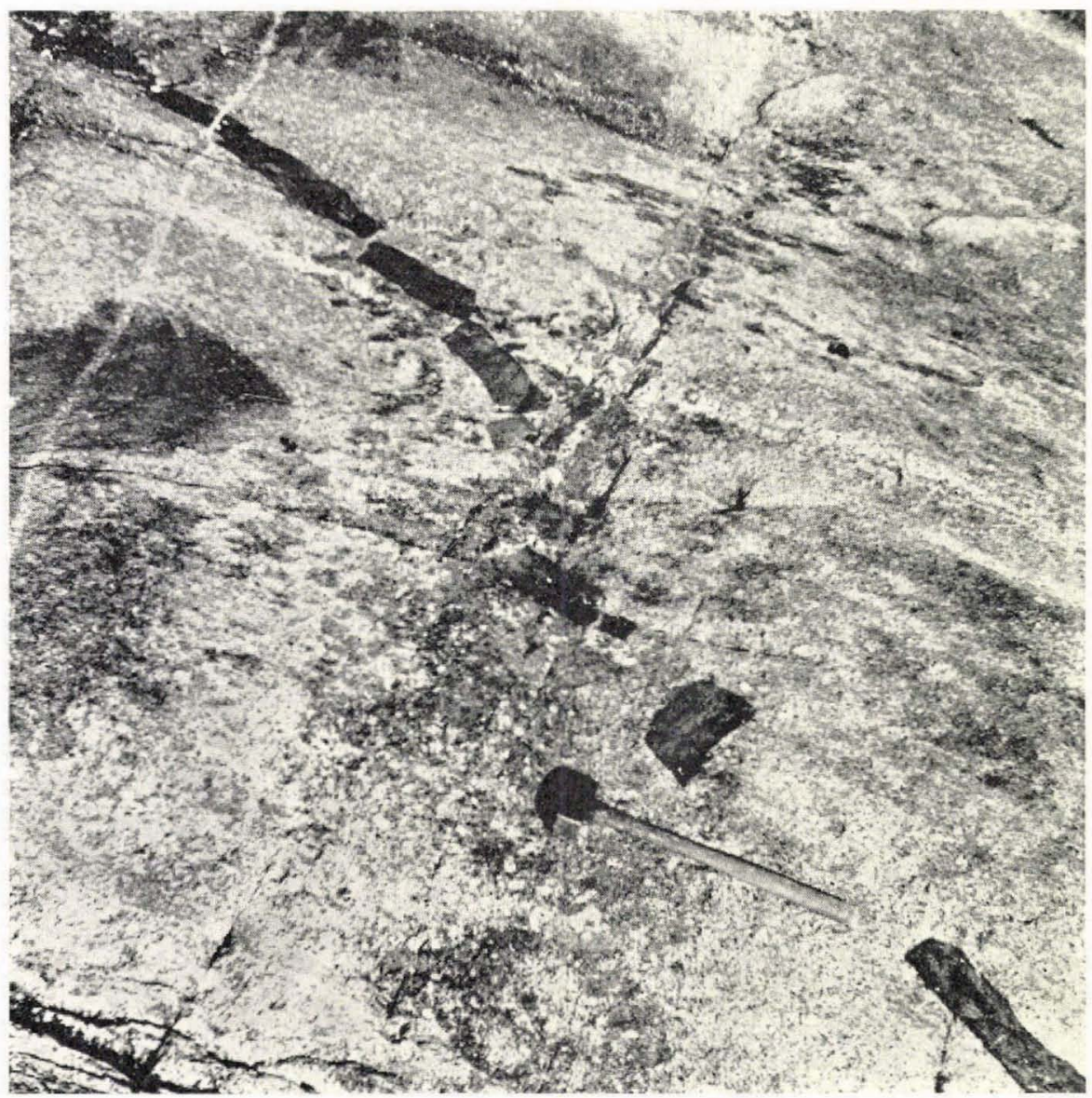

Fig. 45. Disorientation of fragments of synkinematic dyke in Big-feldspar granite. In this case earlier cross-shears have been obliterated. Small island to the east of Niaqornap nunà.

In many places there are pegmatites in dykes perpendicular to their contacts. They are usually spaced at regular intervals and pass across the entire width of the dykes or sheets. Where the pegmatites continue into the country rock they wedge out as soon as they pass the contacts of the dykes. In a few cases these pegmatites continue for some distance into the granite as very thin veins, the attitudes of which are different from those in the dykes. The perpendicular pegmatites have been observed in the metadolerites from Bredefjord, pyroxene-bearing diorites on Pârdlit and surrounding islands and in two localities in the N-S trending synkinematic dyke of Pârdlit.

An example is given in fig. 47 showing the upper contact of a sheet of pyroxene-bearing diorite displaced where it is cut by a perpendicular 


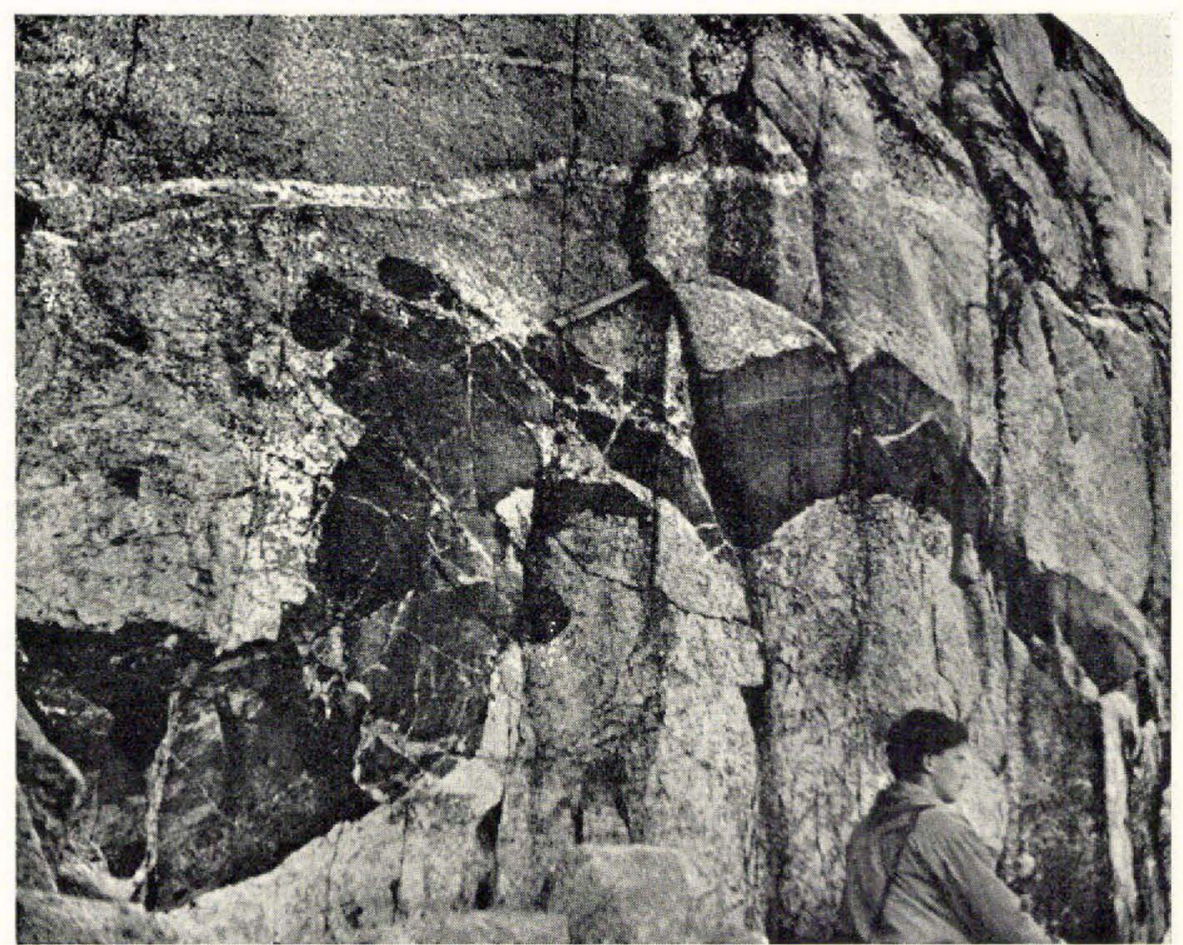

Fig. 46. Fragmented metadolerite the fragments of which are displaced along crossshears and locally bent. Lille Tugtutôq, south-eastern side of Bredef jord.

pegmatite. No trace of shearing can be seen in the granite in line with the pegmatite. The granite was apparently in such a state that it was able to recrystallise and obliterate the shearing phenomena.

The occurrence on Pârdlit of perpendicular pegmatites in a synkinematic dyke belonging to the suite of synkinematic dykes of Julianehåb peninsula, demonstrates their connection with the latest phase of remobilisation in the crust.

Observations on the ENE-trending dyke of pyroxene-bearing diorite on Pârdlit enables the establishment of the age relations of the perpendicular pegmatites to the migmatisation of the second phase of granite development. In this dyke the perpendicular pegmatites occur at regular intervals of about $20 \mathrm{~m}$. Their width varies between $20 \mathrm{~cm}$ and $1 \mathrm{~m}$. In one place such a pegmatite shows a double bayonet structure suggesting that it was emplaced by dilation. In other cases the dilational character is not so clear. The pegmatites transect earlier veins of second phase age in the dyke. In one locality the diorite dyke is displaced for several metres (see fig. 13) by a steep NE-trending sheet of fine- to mediumgrained, leucocratic biotite granite which was emplaced in an earlier 


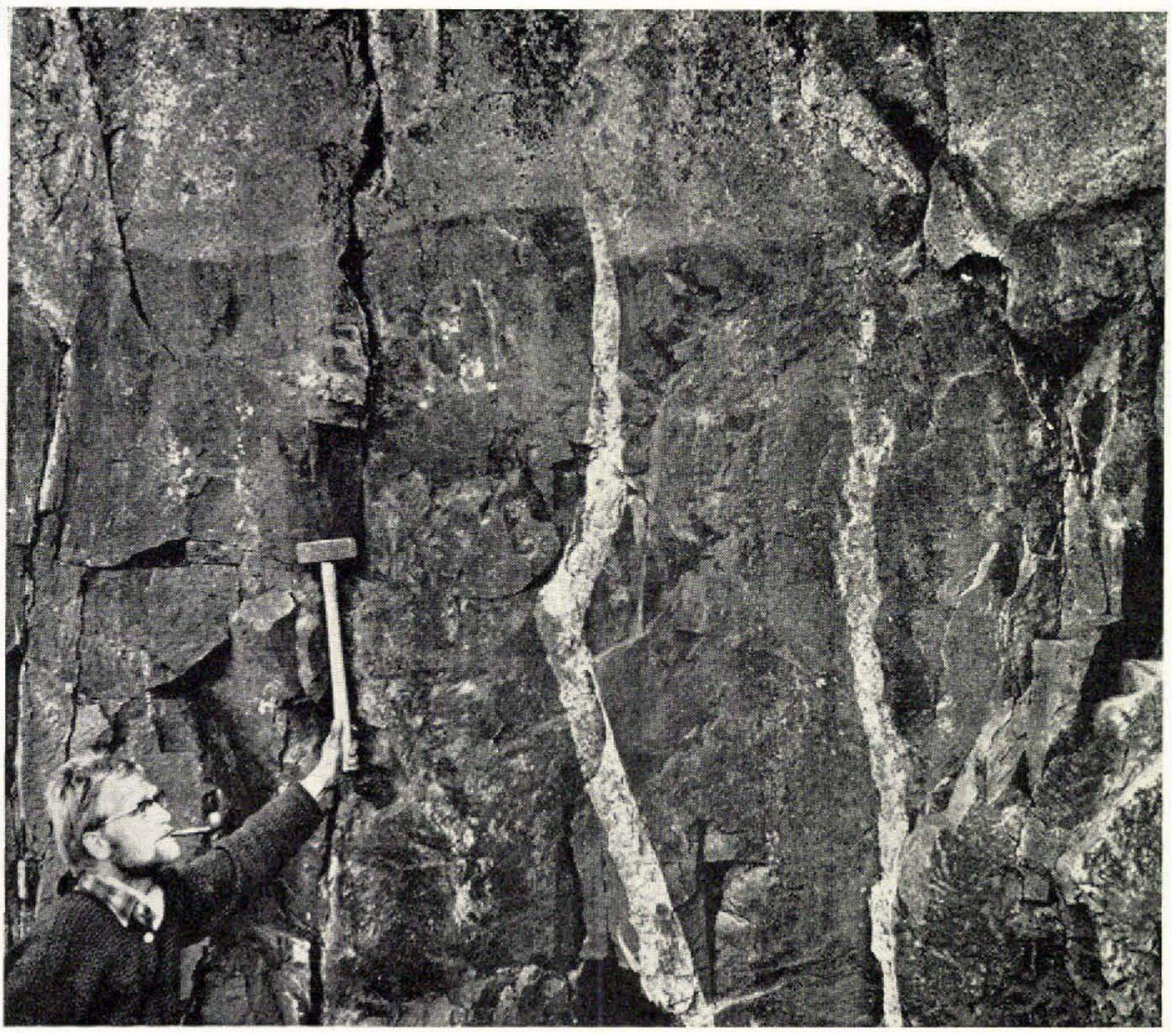

Fig. 47. Pyroxene-bearing diorite with a perpendicular pegmatite displacing the upper contact of the sheet. Small island south-west of Pârdlitt.

hot shear zone. The leucocratic granite crosscuts the second phase granite veins in the dyke, while a perpendicular pegmatite crosscuts an apophysis of the sheet of leucocratic granite which penetrates the dyke.

The fact that the perpendicular pegmatites are confined to dykes and scarcely penetrate the surrounding granite suggests that they were the result of processes during which the dyke body and the surrounding granite behaved differently. This difference is emphasised by comparing these relations with those of dykes and granite to later sets of very regular pegmatite and aplite veins which transect the dykes and granite without any change in direction or width. These veins were evidently emplaced during a later stage of waning plutonism at relatively low temperatures when both dyke and granite were apparently highly brittle. The following sequence of events can thus be established on Pârdlit.

5. Leucocratic veins (brittleness, waning plutonism).

4. Perpendicular pegmatites (latest phase; passive remobilisation).

3. Emplacement of sheet of leucocratic biotite granite in hot shear zone. 
2. Formation of NE-trending hot shear zone.

1. Veining of pyroxene-bearing diorite by country rock granite (second phase of granite development).

Emplacement of the dykes of pyroxene-bearing diorite.

The late phase of remobilisation is marked by disorientation and floating apart of displaced dyke fragments, by recrystallisation and obliteration of the cross-shears and by development of perpendicular pegmatites in the dykes. These pegmatites are probably due to slight stretching of the competent dykes and sheets resulting in opening of perpendicular joints in which the pegmatites grew in pace with the movements. The absence of phenomena reminiscent of typical boudinage suggests that the competency differences between dykes and host granite were great.

The phenomena described in the present subsection occur in restricted areas of wide distribution throughout the area investigated. The fact that smaller bodies of Redekammen type granite are also very common in these areas might suggest that there is a relation between the emplacement of these bodies and the passive remobilisation of the older granites. This relation is however not straightforward and it is even possible that there is a considerable time gap between the leucocratic granites and the remobilisation phenomena.

\section{The net-veined diorites}

The waning stages of plutonic activity in the eastern part of the Julianehåb district are marked by the intrusion of the net-veined diorites and by the emplacement of leucocratic veins and small bodies of leucocratic granite. The diorites form a dense network of sheets and dykes which, as WINDLEY (1965) has shown, form an almost complete garland around an ENE-trending oval-shaped area which comprises the eastern part of the Julianehåb district.

It has been shown in the preceding section that generally during the intrusion of the net-veined diorites the country rock, although not yet completely cold, was practically dead. The net-veins thus did not originate as a result of chemical or physical mobility in the adjacent granite (see in this respect also fig. 1). This setting demonstrates the close connection of the emplacement of the diorite and the formation of the net-veins at the present level of exposure. The source of the netveins has to be sought deeper in the crust and their generation might be connected with rheomorphism at depth (WINDLEY, 1965) or with activity of residual acid liquors (see also p. 109) associated with the declining stages of plutonic activity. 
Throughout the area studied veins and sheets of aplite and pegmatite crosscut the net-veined diorites. In Qaerssuarssuk there are also small bodies of leucocratic granite postdating the diorites (W.атт, 1965),

\section{The tholeiitic dykes}

In the preceding section it has been concluded that the tholeiitic dykes were intruded into country rock which was practically dead (p. 21 and 80). The fact that most of the original pyroxene is replaced by hornblende and that part of the plagioclase is pigmented suggests that after the emplacement of the dykes a slight metamorphism has taken place. The occurrence of hypersthene distinguishes them from the Gardar dolerites which have an alkaline character. Therefore it is suggested that the tholeiitic dykes mark the transition from plutonic to anorogenic conditions in the crust. 


\section{REGIONAL SETTING AND CORRELATION}

\section{Correlation with the adjacent regions}

The chronological evidence presented in section XI suggests that during an earlier plutonic episode supracrustal rocks with possible elements of older basement were metamorphosed, granitised and repeatedly deformed. The knowledge of these plutonic events is however to some extent fragmentary; they were succeeded by the intrusion of the metadolerites and probably some of the hypersthene gabbros. Afterwards further plutonic activity was marked by a phase of deformation closely followed by the emplacement of allochthonous granites. During a subsequent stage of brittleness in the crust dioritic intrusive bodies and perhaps a few plutons of hypersthene gabbro were intruded, and continuing plutonic activity resulted in the formation of the main body of Bigfeldspar granite accompanied by extensive veining of basic and intermediate intrusive bodies in its surroundings. Finally a few major bodies and numerous smaller bodies of leucocratic granite were emplaced. This succession of events is similar to that of the regions more to the southeast and to the west. In both these regions an early episode of plutonism, marked by the regional metamorphism, repeated deformation and granitisation of a series of sediments and volcanic rocks was followed by the intrusion of widespread swarms of doleritic dykes (the so-called 2nd period dykes) and by a subsequent episode characterised by an early phase of deformation and metamorphism and a second phase of emplacement of one or two generations of granite plutons closely connected with basic and intermediate activity. North of Unartoq F jord a still later phase of formation of granitic bodies has been recognised. Throughout the region between Kobberminebugt and Unartoq Fjord there is a break in the plutonic evolution marked by the intrusion of doleritic dykes (2nd period dykes). It is therefore concluded that the so-called 2nd period basic dykes of the surrounding regions can be safely correlated with the metadolerites of the eastern part of the Julianehåb district, and that the correlation of the supracrustal rocks on Mato island and other places in the area investigated with the Ketilidian supracrustals of the TasermiutS. Sermilik and Kobberminebugt regions is reasonable. 


\section{Considerations about the presence of pre-Ketilidian basement in the Julianehåb granite}

It has been suggested in section XII that the host granite of the double-folded possible preorogenic relict dyke from Bredef jord was a granitic rock before this body was affected by the two phases of deformation. This implies that the granite band in question might represent a pre-Ketilidian element in the nebulitic series.

In three widely spaced areas in the eastern part of the Julianehåb district there are occurrences of gabbro-anorthositic rocks (see plate 2). These rocks are closely similar to the gabbro-anorthosites which make up part of the Ivigtut gneisses underlying the pre-Ketilidian Târtoq Group of supracrustals, both of which form the basement of the Ketilidian sediments and volcanics of the Grænseland-Midternæs areas at the northwestern margin of the Ketilidian mobile belt (Higgins and Bondesen, 1966). In one of the three areas, i.e. along Torssukátak fjord the gabbroanorthositic rocks form bands in the nebulitic series.

The occurrence of possible pre-Ketilidian elements in the nebulitic series (variety 1) does not necessarily imply that the gneiss bands of that series are also pre-Ketilidian. It is more sensible to suppose that there are only wedges of pre-Ketilidian basement material in the Ketilidian gneisses. This would mean however, that the basement itself cannot be far away. However, when looking around for that basement only extensive areas of homogeneous granite are found. The conclusion must therefore be drawn that if pre-Ketilidian basement was present in the segment of crust of which the investigated area makes part, it was strongly homogenised as a result of Ketilidian or earlier plutonic events. This might imply that a large part of the granitic rocks in the eastern part of the Julianehåb district represents anatectic pre-Ketilidian basement material. There is a possibility that in Qarmat land and the ground to the southwest an autochthonous relict of that basement has been preserved. In this area mafic granodiorite (variety 3) and Big-feldspar granite (variety 5) are exposed. Major fold structures, trending NW-SE, are well preserved and in one locality there are important bands of gabbro-anorthositic rock.

It has to be noted that in the western part of the Julianehåb district the granite is considered to be 1st episode in age (T. C. R. Pulvertaft, personal communication), but in the same area no evidence can be supplied contradicting the thesis that much of it originated by anatexis of older basement. In this way the homogeneous character of the Julianehåb granite might at least partially be explained as the result of prolonged homogenisation and mobilisation of granitic and gneissic rocks of that basement rather than large scale granitisation of a major segment of geosynclinal deposits during one orogenic cycle or part of it. 
The recognition of relicts of more or less reworked old basement in granitic areas within mobile belts, especially in those which are deeply eroded, is important as the distribution of such relicts might give information about the mode of arrangement of the troughs of geosynclinal sedimentation and about the crustal conditions during the lateorogenic episode of cooling.

\section{Considerations about the crustal conditions within the Ketilidian mobile belt}

As has been indicated before, the Julianehåb district constitutes a region of relatively homogeneous granitic rocks within the Ketilidian mobile belt, the north-western margin of which is situated not far north of Ivigtut (WINDLEY et al., 1966). The south-eastern margin occurs somewhere east of Tasermiut fjord, but where exactly is not yet known. There are possible relicts of old basement in at least the eastern part of the Julianehåb granite region, and it is probable that much of the granite represents anatectic pre-Ketilidian basement. It seems that the homogeneity of the Julianehåb granite had already largely been attained during the earlier stages of the Ketilidian plutonism and partly even earlier.

In the western part of the Julianehåb district (T. C. R. Pulvertaft, personal communication) those granites which are interpreted as being 1 st episode in age constitute large areas between which, here and there, belts and zones of gneiss and supracrustals, mainly with an ENE trend, are preserved. A similar arrangement is clear in the eastern part of the district, but here some of the granite areas were remobilised and became allochthonous during the 2 nd episode of Ketilidian plutonism. In the south-eastern region between Cnartoq Fjord and Tasermiut fjord the syn- to late-kinematic 1st episode granites either form conformable bands or they occur in cores of major antiformal folds (Sermersôq, OEN, 1961; EscheR, 1966). The core granites occur here and there in a region mainly consisting of gneisses and supracrustals, and as a rule the tops of these bodies do not come higher than a few hundred metres above sea level.

These differences in distribution and frequency of the 1 st episode granites might be explained in two ways. 1) The region of Julianehåb granite represents the old foundation of one or more relatively shallow Ketilidian sediment troughs at the north-western side of a deeper and broader trough which occupied the south-eastern region. 2) The two above regions originally formed one broad trough of practically the same depth and the greater part of the Julianehåb district represents the root zone (Walton, 1965, pp. 52,60) of the mobile belt. It is admitted that no evidence is available warranting a choice between the two alternatives. 
In addition, the fact that the work to the south-east of Tasermiut fjord is not yet finished makes any definite statements about the real extension of the mobile belt premature. However, WALTon's root concept allows one to account for certain features concerning the setting of the eastern part of the Julianehåb district. His reasoning (loc. cit., p. 60), slightly adapted to the language used in the present paper, is as follows: At the end of the 1st episode, marked by repeated folding, metamorphism and granitisation, the down-dragging convection currents beneath the orogenic belt decreased in intensity and finally stopped. Due to isostasy, the orogenic pile started to rise up. This suggestion might explain the homogeneity of the Julianehåb district. WaLto (loc. cit., p. 52) expected that in a root zone syntectonic granitisation-homogenisation processes have been most effective. However, the writer would like to point out that in an old mobile belt such as the Ketilidian, the epeirogenetic movements have had time to allow isostatic balance to be recovered. In this way the deeper parts of the geosyncline and also its old reworked foundation which had undergone homogenisation during earlier cycles, might have been raised to such a high crustal level that they have been uncovered by erosion. The fact that at least the eastern part of the Julianehåb district is characterised by the occurrence of possible relicts of the old foundation of the mobile belt favours this suggestion. The eventual conclusion of this line of thought is that the north-western and south-eastern boundaries of the Julianehåb granite roughly mark either a thermal boundary and/or a boundary between different crustal levels within the mobile belt. The probability of this conclusion would increase considerably if it can be shown that the highest grade metamorphic rocks are to be found within the Julianehåb district (see also Watson, 1964, p. 463). There are no indications that high grade rocks originally were present. If they were, they must have been reconstituted beyond recognition into amphibolite facies rocks during the 2nd episode of Ketilidian plutonism, but this is not very probable. In this respect it should be noted that the highest grade rocks of South Greenland are to be found in an area around Tasermiut fjord (Escher, 1966; Dawes, 1965) which in fact is situated much closer to the south-eastern margin of the mobile belt than the Julianehåb district. Up to the present day there are no indications that these high grade rocks represent older basement. Thus it can be expected that the work to be carried out in the region east of this fjord will show that the configuration of thermal culminations and crustal levels in the Ketilidian mobile belt is more complicated than outlined in the present subsection.

WALTON's suggestion that homogenisation has been most effective in a root zone is correct. It should be emphasised however that in the eastern part of the Julianehåb district relicts are to be found (gabbroanorthositic rocks) which possibly have survived plutonic activity 
connected with two orogenic cycles and perhaps even three (see table 1 and WINDLEY et al., 1966). This might suggest that homogenisation in a root zone is not necessarily completed during one orogenic cycle.

In order to develop WaLton's line of thought a little farther it is necessary to quote him again (loc. cit., p. 60): This isostatic upward movement (see above) implies partial tensional conditions in the crust which would allow the intrusion of simatic basic magma. Generally the first expression of this was the intrusion of the metadolerites (the so-called 2nd period basic dykes). As will be explained in the following subsection these dykes are mainly concentrated in the crustal segment constituted by the Julianehåb granite. The reason for this might be that, with the cessation of convection currents, tensional conditions can be expected to have been more pronounced in the deeper parts of the root zone than in the surrounding regions. Moreover, the relative homogeneity of the country rocks in this segment might have been another factor which favoured the intrusion of the metadolerites here.

The earliest stages of the 2nd episode of Ketilidian plutonism are marked by deformation phenomena, which are not necessarily synchronous, throughout the strip of the mobile belt under consideration. In the western part of the Julianehåb district (T. C. R. Pulvertaft, personal communication) hot shear belts were formed in homogeneous 1st episode granites with destruction of the minerals and almost without recrystallisation. More to the east in the region between Qagssimiut and Unartoq Fjord semiplastic deformation, strongly varying in intensity, produced a foliation which generally followed earlier formed planar elements. In the region farther south-east large scale open structures were formed and small scale fracture cleavage developed in accompaniment with faulting $\left(\mathrm{F}_{4}\right.$ of Escher, 1967). In the eastern part of the Julianehåb district the deformation is closely associated with the emplacement of subautochthonous to allochthonous granites (variety 4). This contrasts with the brittle conditions which apparently prevailed more or less contemporaneously in the western part of the Julianehåb district and in the south-eastern region, and reflects differences in crustal conditions between the two latter regions and the eastern part of the Julianehåb district during the early stages of the 2nd episode of Ketilidian plutonism.

In the south-eastern region between Sydprøven and Tasermiut f jord the earliest generation of microcline granite bodies does not seem to be closely connected with deformation (e.g. Sermersôq, Oen, 1961). There the second generation is formed by the bodies of "New granite" (BRIDGWATER, 1963) of which other members seem to occur in the western part of the Julianehåb district and in the Ivigtut region. It is perhaps premature to propose a strict correlation between the microcline granites and 
the allochthonous granites (variety 4) belonging to the first phase of $2 n d$ episode granite development of the eastern part of the Julianehåb district and between the "New granites" with the Big-feldspar granite (variety 5) which belongs to the second phase of granite development in that district. However, if these correlations are supposed to be more or less correct the following features might be of interest. The older microcline granites are petrographically similar to the Big-feldspar granite (second phase in the eastern part of the Julianehåb district), while the younger "New granites" show many characteristics of a rapakivi suite. These differences in petrographic characteristics might reflect differences in crustal conditions in the respective regions during the successive phases of granite development. It has to be emphasised that in a broad belt surrounding the southern part of the body of Bigfeldspar granite the country rock was reactivated during the second phase in the eastern part of the Julianehåb district. In the surrounding regions to the south-east and to the west there are no signs of similar granite activity in the country rocks of the "New granites" comparable in age with the second phase.

Some of the "New granite" bodies have been dated (BridGWater, 1965) giving results of $1,615 \pm 30 \mathrm{~m} . \mathrm{y}$. and 1,620 $\pm 50 \mathrm{~m} . \mathrm{y}$. A new K-Ar age determination (T. J. U URYCH, written communication to D. BRIDGWATER) of hornblende from the subautochthonous Akia granite (WINDLEY, 1966) gave a result of $1,655 \pm 40$ m.y. The field relations of the metadolerites (the so-called 2nd period basic dykes) in the Akia granite suggest that this granite became subautochthonous during the first phase of granite development of the 2nd episode of Ketilidian plutonism (emplacement of variety 4) and the new date might mark the later stages of this phase.

The latest phase of granite development is mainly confined to the eastern part of the Julianehåb district and marked by the emplacement of the Redekammen type granites (variety 6) and by passive remobilisation in earlier granites. An $\mathrm{Rb}$-Sr age determination of biotite from the granite from Pârdlitt (variety 4) resulted in 1,530 \pm 25 m.y. (O. LARSEN, personal communication), and this date is considered to mark the end of the phase of passive remobilisation in the country rock demonstrated on this island (p. 86). An older $\mathrm{Rb}-\mathrm{Sr}$ determination of biotite of the country rock granite (variety 4) in the town Julianehåb is of interest. It resulted in $1,500 \pm 70$ m.y. (Moorbath et al., 1960). Although the granite of the south-eastern part of Julianehåb peninsula has not been affected by this passive remobilisation the temperature there was at that time apparently high enough to produce redistribution of the trace elements. Alternatively the two last dates might be considered to mark the final stages of cooling and uplift of the mobile belt. 
As already remarked by Bridgwater (1965), the lifetime of the 2nd episode of Ketilidian plutonism might thus be of long duration and, as the new age determinations suggest, of the order of $100 \mathrm{~m}$.y. Thus it seems that there was a considerable time interval between the second and third phases of the 2nd episode of Ketilidian plutonism. However, there was no basic or intermediate igneous activity during this interval.

In conclusion there are some indications which suggest that during the 2nd episode of Ketilidian plutonism the crustal conditions in the eastern part of the Julianehåb district were different from those in the surrounding regions to the west and to the south-east. These differences in conditions might reflect either or both of the following alternatives. 1) The eastern part of the Julianehåb district was the site of the last thermal culmination in the mobile belt. 2) This region represents a segment in which granite development took place in a deeper crustal level than in the surrounding regions. Similar alternatives have been suggested by Watson (1964) and Soper (1964) respectively when considering the conditions during late-orogenic cooling in the metamorphic Caledonides of Scotland and Northern Ireland. In view of the possibility that thorough isostatic compensation might have taken place during the final stages of the life of the Ketilidian mobile belt the second alternative is at least as likely as the first.

The oval-shaped garland formed by the network of intrusive bodies of net-veined diorites surrounding the eastern part of the Julianehåb district (WINDLEY , 1965, plate 1) is of interest. It is suggested that this garland encloses the area of latest thermal activity in the crust of the cooling mobile belt.

On map 1 shown by Allaart (1964) it can be seen that the basic and intermediate intrusives which are considered to postdate the 1st episode of Ketilidian plutonism are mainly concentrated in a belt roughly coinciding with the garland defined by the net-veined diorites. This shows that the close association of plutonism and basic to intermediate igneous activity in the eastern part of Julianehåb district already marked earlier stages of the late-orogenic evolution in the crust. However in the surrounding regions the main aspect of this evolution is the development of rapakivi granites and associated basic to intermediate plutons.

\section{The significance of the metadolerites (2nd period dykes) in South Greenland}

The significance of the metadoleritic 2nd period dykes of South Greenland has already been considered several times in earlier papers (e.g. Watterson, 1965; Bridgwater and Walton, 1964; Walton, 1965; BridGWater, 1965). Since these papers appeared some new aspects have arisen which support the suggestions made by the last-mentioned 
authors that the 2nd period metadolerites represent an intraorogenic phase of basic igneous activity. These are as follows.

1) Attempts have been made to correlate the metadoleritic 2nd period dykes with the major swarms of anorogenic basic dykes in the Ivigtut region and farther north. However, the work of HigGins and Bondesen (1966; see also WindLeY et al., 1966) close to the northwestern margin of the Ketilidian mobile belt has shown that virtually none of the dykes of the major swarms cut the Ketilidian basal unconformity. As the metadoleritic 2nd period dykes have been shown to postdate the Ketilidian supracrustals and the 1st episode of Ketilidian plutonism (WATterson, 1965) the correlation of these dykes with the major swarms of anorogenic dykes can be considered as being invalid.

2) Reconsideration of the field relations and petrographical characteristics of the intermediate and basic intrusives in South Greenland necessitates the conclusion that the metadoleritic 2nd period dykes are confined to the region between Onartoq Fjord and Kobberminebugt. This region occupies an apparantly asymmetrical position within the Ketilidian mobile belt and roughly coincides with that constituted by the Julianehåb granite. This is a correction of an earlier statement by Allaart (1964, p. 19). In the same paper (loc. cit., p. 10) another error was made when grouping the pyroxene-bearing diorites, the hypersthene gabbros and the metadolerites from the Julianehåb district together as 2nd period dykes. As has been shown in the present paper these groups belong to different phases of igneous activity which are separated by plutonic activity.

It has to be emphasised that the 2 nd period metadolerites are as a rule very thin, and although they are widespread in the Julianehåb district their total volume is small in comparison with that of the great swarms of dykes which mark major breaks in the lifetimes of mobile belts (RamberG, 1948; Noe-Nygaard, 1952; Sutton and Watson, 1951).

The metadolerites do however mark a break of some sort, and it remains to consider the significance of this break. The available evidence which might give an idea about the crustal conditions during the intrusion episode of the dykes is as follows. The metadolerites are everywhere characterised by relict doleritic texture, although they are generally strongly recrystallised. Chilled margins were recognised in the 2 nd period metadolerites of Ilordleq (WATterson, 1965). Their intrusive structures are identical to those in tensional dykes. This evidence only permits the following conclusions to be drawn. Development of chilled margins only indicates relative temperature differences of about $500^{\circ} \mathrm{C}$ between the intrusive body and its wall rock (WATtERson, 1965, p. 126) and suggests nothing about absolute temperatures of the wall rock during the intrusion of the dykes. In addition it has to be noted that the pyroxene-bearing 
diorites, which typically belong to a plutonic environment, also display chilling against their wall rocks (see also WALTon, 1965, p. 54). Doleritic textures only indicate crystallisation of magma in the absence of stress and deformation, but they occur in basic igneous rocks of plutonic as well as of anorogenic environments. The typical intrusive structures of the metadolerites indicate that the crust was brittle, but not that it was cold. Therefore it can only be concluded that the intrusion of the metadolerites reflects a tendency in the crust towards release of stress, brittleness and probably towards a retreat of the geo-isotherms. That the crust was under conditions identical to those of typical anorogenic environments is improbable as is suggested by the intimate association in time of basic and intermediate intrusions with the subsequent plutonic activity and the evident petrographical and chemical links between the metadolerites and these intrusions.

It seems that the famous metabasaltic dykes described by SEDERHoLm $(1923,1926,1934)$ from South Finland, predating the generation of the Hangö granite, are closely similar in appearance and field relations to the metadolerites from South Greenland. The Sederholm dykes are at present considered to represent an episode of intraorogenic basic igneous activity (Simonen, 1960, p. 88; Edelman, 1949), while the southwestern part of Finland where the Hangö granite is mainly concentrated is supposed by MetzGer (1959, p. 10, fig. 1) to represent anatectic old basement in the Svecofennian fold belt.

\section{Evaluation of the significant features of the basic and intermediate intrusives}

The conclusion that the metadolerites (2nd period dykes) of South Greenland could belong to a plutonic environment helps to end a controversy which for many years has concerned the team of workers in South Greenland. Workers from the Ivigtut region and West Greenland have produced evidence that the major swarms of basic dykes from these regions are much older than the 2 nd period metadolerites. If the metadolerites represented a major break in plutonism it would be dif ficult to accommodate both this break and that represented by the major dyke swarms into the chronological framework of South Greenland. The better understanding is accentuated by the fact that the metadolerites are mainly concentrated in the segment constituted by the Julianehåb granite and by the suggestion that the crustal conditions in the southeastern region did not permit intrusion of doleritic dykes there. These considerations make it clear that only detailed investigations in major 
crustal segments permit correct evaluation of the significance of basic to intermediate intrusives.

There are similar difficulties with some of the other rock types described in the preceding sections. Of the noritic gabbros from the south-eastern region Bridgwater (1963) suggested that their intrusion is closely connected with the earlier stages of emplacement of his "New granite" plutons. In the eastern part of the Julianehåb district the hypersthene gabbros are arranged in an ENE-trending belt where also the net-veined diorites are concentrated Here the hypersthene gabbros are not only found within Big-feldspar granite but also far away, and they show no obvious connection in time with this granite (possibly comparable in age with the "New granites"). Therefore, and for a few other reasons mentioned on p. 100, the writer is more inclined to correlate at least some of the hypersthene gabbros with the metadolerites. $\mathrm{He}$ is even tempted to suggest that the metadolerites originated from the same magma as the hypersthene gabbros. There is no possibility of substantiating this suggestion as the metadolerites are without exception strongly recrystallised. The writer is aware that his colleagues would emphasise the fact that the hypersthene gabbro plutons of the eastern part of the Julianehåb district are either situated within the Big-feldspar granite or within or close to the contacts of the allochthonous JulianehåbIgaliko granite body (variety 4) which is considered to be early 2 nd episode in age. This could imply that one group of gabbros might be connected with the earlier allochthonous granites and a second group with the Big-feldspar granite. No evidence can be supplied against this suggestion. However it might be that both suggestions contain elements of truth. The difficulties are perhaps more a result of too great an inclination for pigeonholing various events than their reality.

There are also some difficulties with the synkinematic dykes. In the eastern part of the Julianehåb district these intrusive bodies seem either to be closely connected with the latest consolidation processes within an early 2nd episode allochthonous granite body (variety 4) or within still later leucocratic granites. In the western part of the Julianehåb district and the Sârdloq and Unartoq areas important concentrations of synkinematic dykes occur. In these areas there is no connection between dyke intrusion and granite emplacement. In the north-western margin of the fold belt and in the south-easternmost region synkinematic dykes are absent or rare respectively. The concentrations at both sides of the area possibly marked by the latest thermal activity in the fold belt might be connected with the retreat of the geo-isotherms in the two areas around the eastern part of the Julianehåb district. 


\section{Chemistry of some of the basic and intermediate intrusives}

Petrographic observations on the metadolerites, hypersthene gabbros and the pyroxene-bearing diorites show that the differences in composition between the rock types could be the result of magmatic differentiation of an original basic magma, but the possibility of assimilation of granitic country rock cannot be ruled out. The widespread occurrence of primary anhydrous minerals, such as clinopyroxene, olivine, hypersthene and basic to intermediate plagioclase, suggests that the magmas of these bodies were relatively dry during their intrusion and it seems that the amount of primary water-bearing silicates, such as hornblende and biotite, to crystallise was small, part of these minerals originating as a result of subsequent plutonic activity. These characteristics contrast with those of the synkinematic dykes and the net-veined diorites in which only hornblende and possibly also biotite occur as primary mafic minerals. This indicates, as Yoder and TrLley (1962, p. 455) have shown, that the magmas of the latter two groups of basic and intermediate intrusives crystallised in the presence of an excess of water and/or high water pressure. As leucocratic veining (aplites and pegmatites) is much more frequent during the intrusion of the net-veined diorites and the synkinematic dykes than during the intrusion episodes of the three older groups, it is suggested that the differences in water content of the respective magmas had a connection with the available residual liquids and volatiles in the crust at the times of their respective intrusions. Possibly these differences might be used as a criterion to distinguish basic and intermediate intrusions connected with early stages of granite development from those connected with terminal stages of granite development.

The chemistry of the basic to intermediate intrusives suggests that they belong to the calc-alkali series. It is clear that all the intrusives under consideration belong to a typical plutonic environment.

\section{The development of the chronological terminology}

During the last decade there has been general agreement within the GGU team about the main lines of the succession of the most important events which operated in the crust of South Greenland. In addition there has always been mutual understanding about the difficulties in evaluating the significance of some of the above events. However in their publications the GGU workers have produced a wide variety of interpretations. This was the result of slight variations in naming of the developed time divisions and of variations in the interpretations about age relationships of the respective events which produced the following: 
a) the formation of the Ivigtut gneisses at the north-western margin of the Ketilidian fold belt;

b) the deposition of the supracrustals of the belt between Grænseland and Kobberminebugt; these were defined by WEgmann (1938) as Ketilidian;

c) the deposition of the supracrustals around the Tasermiut and S. Sermilik fjords of the south-easternmost region;

d) the major dyke swarms (Kuanitic dykes of Berthelsen, 1960, p. 150; Bondesen and Henriksen, 1965) from West and South Greenland which continue far into the Ivigtut gneisses;

e) the 2nd period dykes (metadolerites) of the Julianehåb district.

Berthelsen $(1960,1961)$ arranged his chronological interpretation as follows:

Gardar cycle

Sanerutian period

Kuanitic period

Ketilidian cycle faulting, dyking, alkaline

igneous centres

reactivation ( $\mathrm{SE}$ of Arsuk)

Fjord)

Nagssugtoqidian fold intrusion of the Kuanitic belt (West Greenland)
dykes

(late- to post-kinematic granites (Julianehåb granite) repeated folding $;$ "migmatisation and gneissification (Ivigtut gneisses)

sedimentation, volcanism (Kobberminebugt-

Grænseland; S. Sermilik-Tasermiut)

His starting points were the supracrustals of the KobberminebugtGrænseland belt, already defined by WEGMANN (1938) as Ketilidian, and those of the S. Sermilik-Tasermiut region. The boundary between supracrustals and the Ivigtut gneisses was interpreted as a migmatite front originating during Ketilidian plutonism; the Ivigtut gneisses were thus interpreted as originally belonging to the same cycle of sedimentation as the supracrustals. Berthelsen defined the Kuanitic period as the time span during which the Kuanitic dykes were intruded, and the Sanerutian as the period after the intrusion of the Kuanitic dykes and before the beginning of the Gardar cycle. Berthelsen (1961, p. 333) believed that the Kuanitic dykes, which are amphibolitised and more or less transformed in the area south-east of Arsuk f jord, could be traced right into the vast area of Julianehåb granite to the south. This implied correlation of the Kuanitic dykes with the 2 nd period metadolerites of the Julianehåb district. He admitted that the full significance of the Sanerutian (post-Kuanitic) processes was not yet fully understood. This was an important point, but his premisses that the Ivigtut gneisses and the 
Kobberminebugt-Grænseland supracrustals were deposited at the same time, and that the Kuanitic dykes and the 2nd period metadolerites were of the same age, forced him to suggest (loc. cit. p. 337) correlation of "the Sanerutian reactivation of the old dyke-cut Ketilidian chain in South Greenland with the Nagssugtoqidian orogeny which has left its traces far to the north in West Greenland". His interpretation thus included two orogenic cycles, the plutonisms of which were considered to have taken place respectively about 2,500 m.y. (Ketilidian) and 1,600 m.y. (Sanerutian-Nagssogtuqidian) ago.

Detailed investigation of the field relationships of the Ketilidian supracrustals of Grænseland by A. BertheLSEN and mainly by BondeSEN $(1962$; in prep.) showed that the supracrustals were separated from the underlying gneisses by a major unconformity. This constituted the first factual evidence in support of Wegmann's $(1939,1948)$ suggestion that the Ivigtut gneisses represented pre-Ketilidian basement; moreover this was the first step in the removal of a few erroneous elements from Berthelsen's interpretation. Windeey et al., (1966) have described how the unconformity becomes gradually deformed and gneissified when traced south, so that it eventually simulates a migmatite front.

The work done by WatTerson (1965) in a key area at the border between the Grænseland-Kobberminebugt belt of supracrustals and the north-western side of the Julianehåb district showed that the deposition of the sediments and volcanics was followed by their deformation and metamorphism and afterwards by the generation of the Julianehåb granite. Subsequently numerous thin doleritic dykes (2nd period dykes) were intruded, while during a later episode of plutonic activity the granite was reactivated. These results and those obtained by Bondesen led Watterson $(1965$, p. 132) to suggest that the Kuanitic dykes could be correlated with the Ketilidian volcanic rocks which make up part of the series of supracrustals and this implied that the greater part of these dykes might be much older than the 2nd period metadolerites. This was the reason why the latter author questioned the status of the Kuanitic and Sanerutian periods as originally defined by Berthelsen. It became therefore necessary to build up a terminology for the Julianehåb district which for the time being was independent from that of the Ivigtut region. Consequently Watrerson proposed a redefinition of the Sanerutian (loc. cit., p. 132) "as the plutonic episode during which the 2nd period metadolerites in Ilordleq and other areas of the Julianehåb region were metamorphosed, deformed and their granitic country rock reactivated". The Kuanitic period (loc. cit., p. 43) was redefined as "the episode during which the 2nd period metadolerites were intruded". Watterson summarised his suggestions in the following table (loc. cit., 
p. 134). Brackets enclose interpretations which were suggested as possible alternatives to current correlations.

7. Gardar intrusive and extrusive volcanicity, faulting, continental sandstones.

6. Sanerutian plutonic activity, emplacement of 3rd period dykes. 5 . intrusion of 2nd period dykes [supracrustal rocks, including those of the S. Sermilik-Tasermiut region?].

4. Ketilidian plutonic activity [only S and SE of Arsuk fjord?].

3. supracrustal rocks of the Kobberminebugt-Grænseland belt, 1st period dykes.

2. plutonic activity [formation of Ivigtut gneisses from supracrustal series?].

1. (supracrustal rocks).

An important improvement in this terminology, when compared with that of BERTHELSEN, was the redefinition of the Sanerutian and the Kuanitic episodes. These definitions left open the questions whether the 2nd period metadolerites were intra- or interorogenic and whether the Sanerutian represented the main plutonic episode of an orogenic cycle or an episode of granite emplacement representing the closing of an earlier main orogenic episode. The terminology which was developed as a standard in GGU after WatTerson's and Bondesen's work is indicated in the last column of table 1 (p. 8). The constructive elements of WATTERSON's contribution are somewhat obscured in his own paper. In his chronological table reproduced above, he suggested correlation of the 2nd period metadolerites from the Julianehåb district with the supracrustals of the Tasermiut-S. Sermilik region further to the south-east. There is little doubt that these supracrustals made up part of an orogenic geosynclinal series, so that it is clear that each of the three episodes of plutonic activity distinguished were supposed to represent a main episode of plutonism of three orogenic cycles. WATTERson's correlation was inspired by Wegmann's $(1938$, p. 55) suggestion that the series of gneiss and supracrustals from the south-eastern region is "jammed against some blocks which must have been situated north of it somewhere in the Julianehåb region". The occurrence of gabbro-anorthositic rocks in the Julianehåb granite makes a correlation of the "Julianehåb block" of WeGMAN with the Ivigtut gneisses more probable and WatTerson's suggested correlation less plausible.

Bridgwater (1965) and Walton (1965) accepted Wegmann's correlation of the Grænseland-Kobberminebugt supracrustals with those of the Tasermiut-S. Sermilik region. They pointed out that the Sanerutian plutonic episode was probably not preceded by geosynclinal sedimentation. 
In addition WALTON emphasised that many of the basic and intermediate intrusive bodies in the Julianehåb district and in the south-eastern region constituted a late-orogenic appinitic suite. Most of these are early 2nd episode in age or slightly older. WaLton (loc. cit.) pointed out that the Ketilidian plutonic episode (in the sense as indicated in the last column of table 1) is principally characterised by repeated deformation and synto late-kinematic granitisation and the Sanerutian episode by reactivation of earlier granites and emplacement of major granite plutons in close association with basic and intermediate igneous activity. The suggestion was therefore made that the two episodes might be regarded as forming part of a major unified cycle of development in the crust. The two authors mentioned also suggested that the later alkaline igneous activity of the Gardar period constituted the chracteristic post-orogenic phase of this cycle. Walton (loc. cit.) even suggested that the Gardar sandstones exposed in a down-faulted area in the eastern part of the Julianehåb district might represent the relicts of a late- or post-orogenic molasse series.

Now that the break represented by the anorogenic basic dykes of the Ivigtut region and farther north (BERTHELSEN's Kuanitic dykes) is known to be pre-Ketilidian, and it has been shown that the 2nd period metadolerites are most likely intraorogenic, it is best to accept BRIDGWATER's and WaLton's ideas and to draw the logical conclusion that the terms Kuanitic and Sanerutian are superfluous. This is also the reason that on p. 7 the designation Ketilidian has been redefined and widened at the expense of the Kuanitic and Sanerutian in accordance with the suggestion of WaLton in discussion during the spring of 1964. As will be clear all of the interpretations referred to in the foregoing pages are based on some sort of cycle concept and this seems unavoidable in Precambrian geology. When examining the evolution in mobile belts it is in the writer's opinion recommendable to follow the suggestions put forward by Sutron (1965). When proceeding along these lines of thought an approximate indication of the life-span of the Ketilidian mobile belt might be given by the time (see table 1) between the initiation of the sedimentation in Grænseland and the initial deposition of the Gardar sandstones, which, as WALton (loc. cit.) suggested, might be considered as relicts of a molasse series. It should however be emphasised that the Grænseland sediments do not necessarily represent the oldest trough of sedimentation of the mobile belt. 


\section{Acknowledgements}

I am grateful to the director of the Survey, mag. scient. K. ELLITsGAaRD-RASMUSSEN, for constant support in providing facilities and for permission to publish the work. Sincere thanks are due to Prof. J. Sutron and especially to T. C. R. Pulvertaft for criticism which enabled me to improve an early draft of this paper considerably. Dr. B. F. WindLEY kindly corrected the English. I am indebted to all my colleagues for illuminating discussions, to B. I. Borgen for the chemical analyses and to the personnel of the Survey for their assistance which made the work possible.

May 1966 


\section{REFERENCES}

Allaart, J. H., 1964: Review of the work on the Precambrian basement (PreGardar) between Kobberminebugt and Frederiksdal, South Greenland. Grønlands geol. Unders. Rapp. nr 1.

Ayrton, S. N. and Burri, M., 1967: L'évolution du socle précambrien dans la région de Qagssimiut, Groënland méridional. Medd. Grønland, Bd. 175, nr 2.

Berrangé, J. P., 1966: The bedrock geology of "Vatnahverfi", Julianehåb district, South Greenland. Grønlands geol. Unders. Rapp. nr 3.

Berthelsen, A., 1960: An example of a structural approach to the migmatite problem. Rep. 21st Intern. geol. Congr. Norden, pt 14, 149-157.

- 1961: On the chronology of the Precambrian of Western Greenland. In RaAsca, G. O. (edit.) Geology of the Arctic. v. 1, 329-338. Toronto U. P.

- and Noe-Nygaard, A., 1965: The Precambrian of Greenland. In Rankama, K. (edit.) The Precambrian. v. 2, 113-262. London \& New York: Interscience Publ. [MS submitted Oct. 1963].

Blake, D. H., Elwell, R. W. D., Gibson, I. L., Skelitorn, R. R. and Walker, G. P. L., 1965: Some relationships resulting from the intimate association of acid and basic magmas. Quart. J. geol. Soc. Lond., v. 121, pt 1, 31-49.

BondESEN, E., 1962 : Grænseland Kompleksets geologi. Unpublished prise dissertation. University of Copenhagen.

- (in prep.): The stratigraphy and deformation of the Precambrian rocks of the Grænseland area, South-west Greenland. Medd. Grønland.

- and Henriksen, N., 1965: On some Precambrian metadolerites from the central Ivigtut region, SW Greenland. Medd. Grønland, Bd. 179, nr 2.

Bridgwater, D., 1963: A review of the Sydprøven granite and other "New granites" of South Greenland. Medd. dansk geol. Foren., Bd 15, 167-182.

- 1965: Isotopic age determinations from South Greenland and their geological setting. Medd. Grønland, Bd 179, nr 4 .

- and Walton, B. J., 1964: The tectono-magmatic evolution of the Svecofennid chelogenic cycle in South Greenland. Nature, Lond., v. 203, 278--281.

Burri, C., 1959 : Petrochemische Berechnungsmethoden auf äquivalenter Grundlage. Basel-Stuttgart, Birkhäuser Verlag.

- und NiggLI, P., 1945: Die jungen Eruptivgesteine des mediterranen Orogens. 1er Hauptteil "Die Ophiolite". Vulkaninstitut Immanuel Friedlander, Publ. nr 3.

DAwES, P. R., 1965: The genesis of rapakivi granite and its position in the evolution of the Precambrian of the Tasiussak area, South Greenland. Unpublished Ph. D. thesis, Exeter Univ., England.

Escher, A. E., 1966: The deformation and granitisation of Ketilidian rocks in the Nanortalik area, S. Greenland. Medd. Grønland, Bd 172, nr 9.

- 1967: Tectonic levels in the Precambrian of South Greenland. In Etages tectoniques. Colloque de Neuchâtel 18-21 avril 1966,141-150.

Neuchâtel: Éditions de la Baconnière. 
Higgins, A. K. and Bondesen, E., 1966: Supracrustals of pre-Ketilidian age (the Tartoo Group) and their relationships with Ketilidian supracrustals in the Ivigtut region, South-West Greenland. Grønlands geol. Unders. Rapp. nr 8.

Metzger, A. A. T., 1959: Svekofenniden und Kareliden. Eine kritische Studie. Acta Acad. åbo. Math. et Phys. v. 21, nr 16.

Nes вiтt, R. W., 1961: The petrology and structure of the country around Julianehaab, south-west Greenland. Unpublished Ph. D. Thesis, Durham Univ., England.

Noe-Nygaard, A., 1952: A new orogenic epoch in the Pre-Cambrian of Greenland. Rep. 18th Intern. geol. Congr. London, pt 13, 199-204.

Oen, I. S., 1961: Report on field work on Sermersôq island. Internal GGU report.

PERSOz, F., in press: Évolution plutonique et structurale de la prêsqu' île d'Akuliaruseq, Groenland méridional. Medd. Grønland, Bd 175, nr 3.

RAMBERG, H., 1949: On the petrogenesis of the gneiss complexes between Sukkertoppen and Christianshaab, West Greenland. Medd. dansk geol. Foren. Bd 11, Hf. $3,312-327$.

Ramsay, J. G., 1963: Structure and metamorphism of the Moine and Lewisian rocks of the North-West Caledonides. In Johnson, M. R. W. and Stewart, F. H. (edit.) The British Caledonides. 143-175. Edinburgh: Oliver and Boyd.

ReAD, H. H., 1957: The granite controversy. London: Murby.

Scharbert, H. G., 1958: Kartierungsbericht für die Sommer-Saison 1958. Internal GGU report.

Sederholm, J. J., 1923: On migmatites and associated Pre-Cambrian rocks of Southwestern Finland. I. The Pellinge region. Bull. Comm. géol. Finl., nr 58.

- 1926: On migmatites and associated Pre-Cambrian rocks of Southwestern Finland. II. The region around Barösundfjärd $W$ of Helsingfors and neighbouring areas. Bull. Comm. géol. Finl., nr 77.

- 1934: On migmatites and associated Pre-Cambrian rocks of Southwestern Finland. III. The Åland Islands. Bull. Comm. géol. Finl., nr 107.

Simonen, A., 1960: Plutonic rocks of the Svecofennides in Finland. Bull. Comm. géol. Finl., nr 189.

Sitter, L. U. DE, 1962: Structural geology. (2nd ed.) New York: McGraw-Hill.

Soper, N. J., 1964: Correspondence on paper of Watson, 1964. Geol. Mag., v. 101, nr. 5, 567-568.

Sutron, J., 1965: Some recent advances in our understanding of the controls of metamorphism. In Pitcuer, W. S. and Flinn, G. W. (edit.) Controls of metamorphism, 22-45. Edinburgh: Oliver and Boyd.

- and Watson, J., 1951: The pre-Torridonian metamorphic history of the Loch Torridon and Scourie areas in the North-west Highlands and its bearing on the chronological classification of the Lewisian. Quart. J. geol. Soc. Lond., v. 106, 241-296.

Upton, B. G. J., 1962: Geology of Tugtutôq and neighbouring islands, South Greenland. Part I. Medd. Grønland, Bd 169, $\mathrm{nr} 8$.

Ussing, N. V., 1912: Geology of the country around Julianehaab, Greenland. Medd. Grønland, Bd 38.

WALToN, B. J., 1965: Sanerutian appinitic rocks and Gardar dykes and diatremes, north of Narssarssuaq, South Greenland, Medd. Grønland, Bd 179, nr 9.

Watson, J., 1964: Conditions in the metamorphic Caledonides during the period of late-orogenic cooling. Geol. Mag., v. 101, nr 5, 457-465.

- 1965: Lewisian. In Craig, G. I. (edit.) The geology of Scotland. 49-77. Edinburgh: Oliver and Boyd. 
WATt, W. S., 1965: Textural and field relationships of basement granitic rocks, Qaersuarssuk, South Greenland. Medd. Grønland, Bd 179, nr 8.

Watterson, J., 1965: Plutonic development of the Ilordleq area, South Greenland. Part I. Chronology, and the occurrence and recognition of metamorphosed basic dykes. Medd. Grønland, Bd 172, nr 7.

Wegmann, G. E., 1938: Geological investigations in Southern Greenland. Part I. On the structural divisions of Southern Greenland. Medd. Grønland, Bd 113, nr 2.

- 1948: Note sur la chronologie des formations précambriennes du Groenland méridional. Ecl. geol. Helv., v. 40, 7-14.

WindLEY, B. F., 1965: The composite net-veined diorite intrusives of the Julianehåb district, South Greenland. Medd. Grønland, Bd 172, nr 8.

- 1966 a: The Precambrian geology of the Sârdloq area, South Greenland. Grønlands geol. Unders., Rapp. nr 5.

- 1966 b: Superposed deformations of the Ketilidian gneisses in the Sârdloq area, South Greenland. Medd. Grønland, Bd 179, nr 3.

- , Henriksen, N., Higgins, A. K., Bondesen, E. and Jensen, S. B., 1966 : Some border relations between supracrustal and infracrustal rocks in Southwest Greenland. Gronlands geol. Unders. Rapp. nr 9.

Winkler, H. G. F., 1965: Die Genese der metamorphen Gesteine. Berlin: Springer Verlag.

Yoder, H. S. and Tilley, C. E., 1962: Origin of basalt magmas: An experimental study of natural and synthetic rock systems. J. Petrol. Oxford, v. 3, pt 3, 342-532.

Færdig fra trykkeriet den 31. december 1967. 
PLATES 
Plate 1

Double-folded, possible preorogenic dyke relict passing through a concentration of basic inclusions (black) in granite (variety 1) and crosseut by a non-folded meta-
dolerite dyke. Lille Tugututóg, south-eastern side of Bredef jord.
GRØNLANDS GEOLOGISKE UNDERSØGELSE

THE GEOLOGICAL SURVEY OF GREENLAND

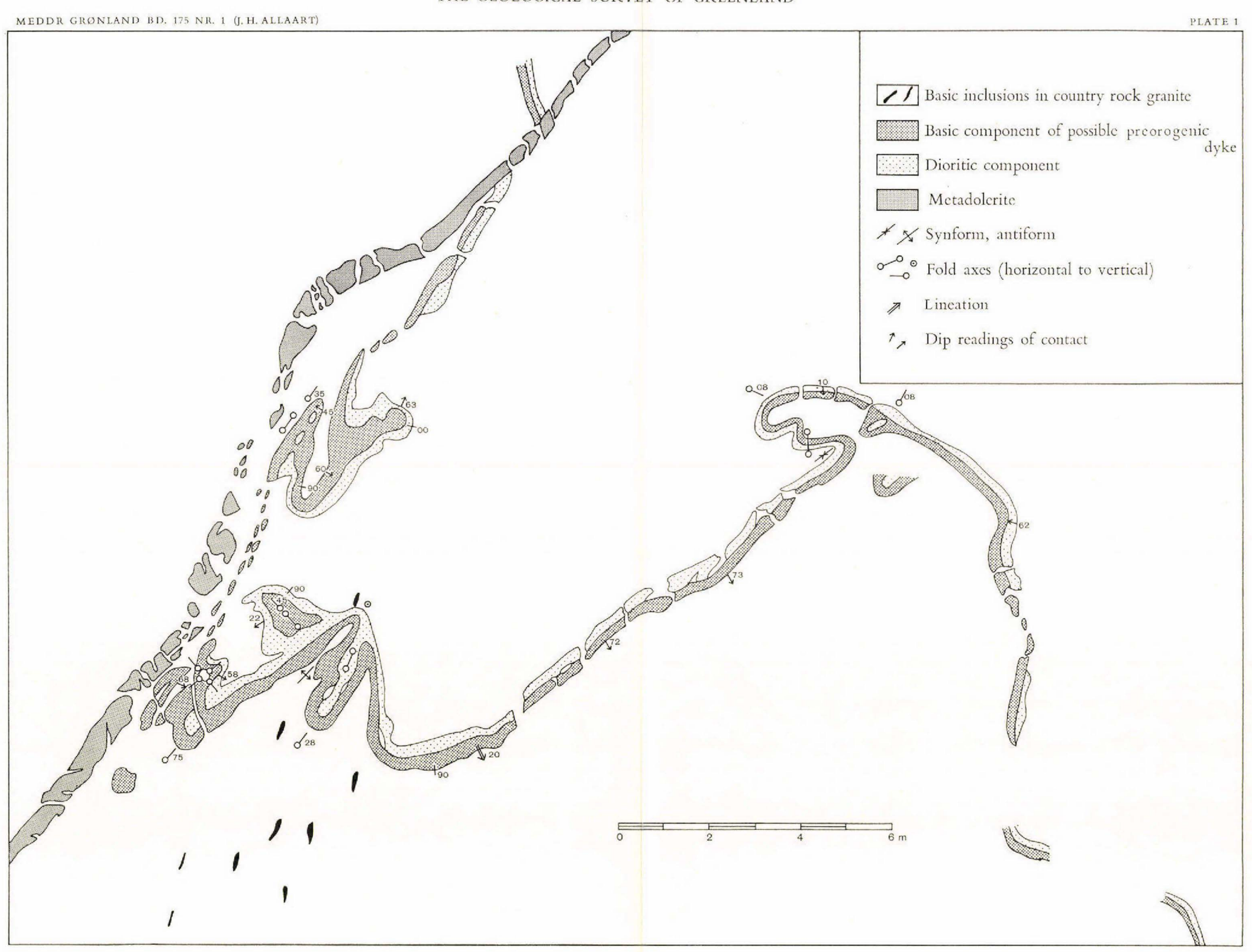


GRøNLANDS GEOLOGISKE UNDERSØGELSE HE CSOLOGCAL SURVEY OF GRFFNAND

Plate 2

General map of South Greenland indicating the region of Juliancháb granite with occurrences of possible prearogenic dykes and gabbro-anorthositic rocls.

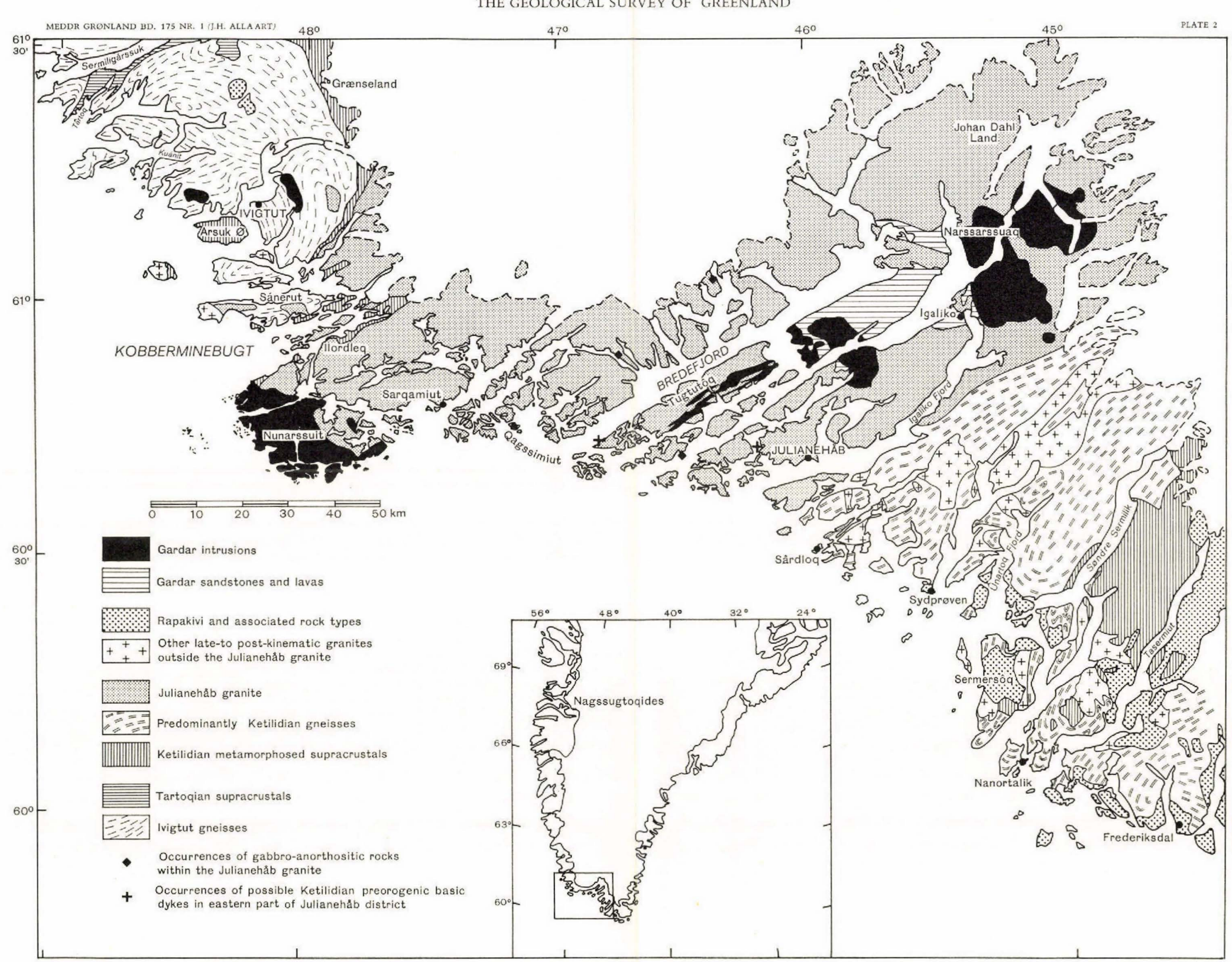


Plate 3

The granites of the eastern part of the Julianeháb district. The orientation of the non-eq

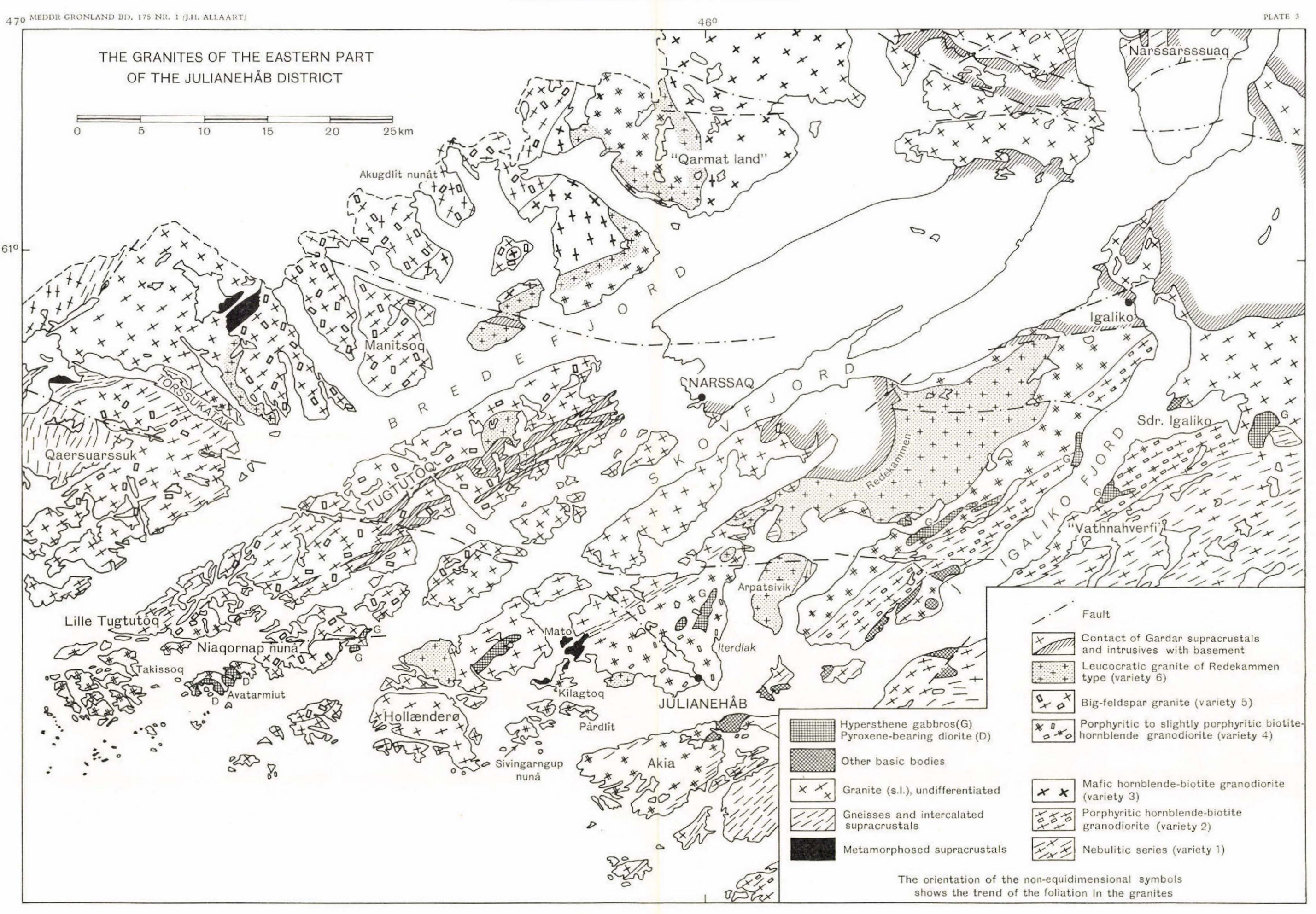

